\section{CIHM} Microfiche Series (Monographs)
ICMH

Collection de microfiches (monographies)

Canadian Institute for Historical Microreproductions / Institut canadien de microreproductions historiques
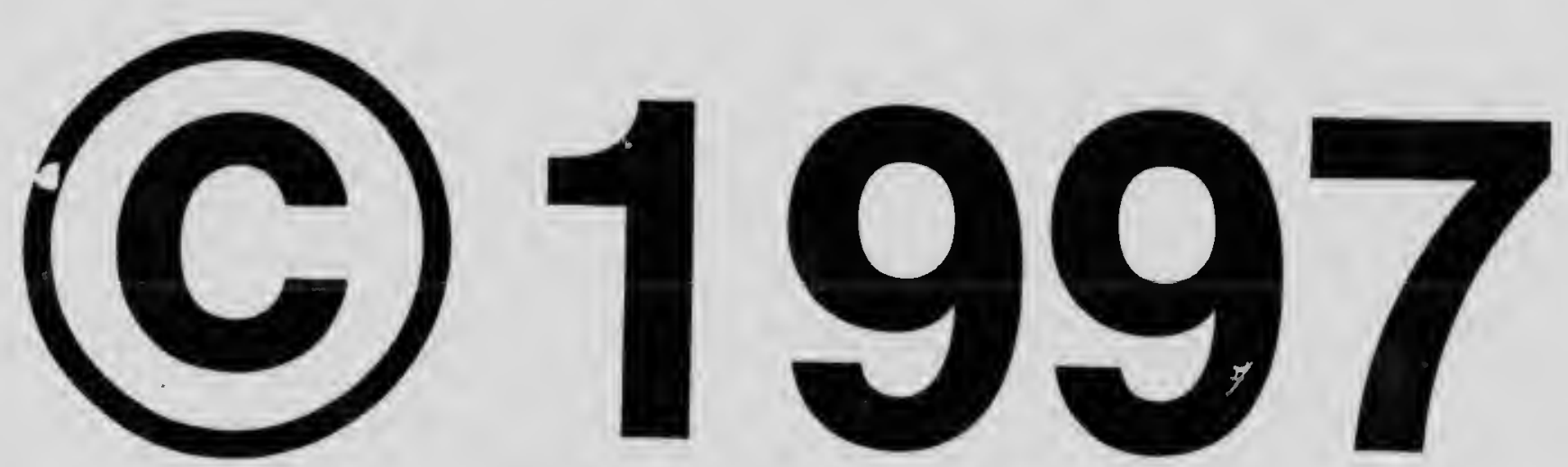


\section{Technical and Bibliographic Notes / Notes technique at bibliographiques}

The Institute has attempted to obtain the best original copy available for filming. Features of this copy which may be bibliographically unique, which may alter any of the images in the reproductlon, or which may significantly change the usual method of filmlng are checked below.

\section{Coloured covers /}

Couverture de couleur

Covers damaged /

Couverture endommagée

\section{Covers restored and/or laminated /}

Couverture restaurée etou pelliculée

Cover title missing / Le titre de couverture manque

Coloured maps / Cartes géographiques en couleur

Coloured ink (i.e. other than blus or black) /

Encre de couleur (i.e. autre q(': t)leue ou noire)

Coloured plates and/or illustrations !

Planches etou illustrations en couleur

Bound with other material /

Relié avec d'autres documents

Only edition available /

Seule édition disponible

Tight binding may cause shadows or distortion along interior margin / La reliure serrée peut causer de l'ombre ou de la distorsion le long de la marge intérieure.

Blank leaves added during restorations may appear within the text. Whenever possible, these have been omitted from filming / II se peut que certaines pages blanches ajoutées lors d'une restauration apparaissent dans le texte, mais, lorsque cela était possible, ces pages n'ont pas été filmées.

\section{Additional comments /}

Commentaires supplémentaires:
L'Institut a microfilmé le meilleur exemplaire qu'il lui a été possible de se procurer. Les détails de cet exemplaire qul sont peut-être unlques du point de vue bibllographique, qul peuvent modifier une image reproduite, ou qul peuvent exiger une modification dans la méthode normale de filmage sont indiqués ci-dessous.

Coloured pages / Pages de couleur

\section{Pages damaged / Pages endommagées}

Pages restored and/or laminated /

Pages restaurées etou pelliculées

Pages discoloured, stained or foxed /

Pages décolorées, tachetées ou piquées

Pages detached / Pages détachées

\section{Showthrough / Transparence}

Quality of print varies /

Qualité inégale de l'impression

Includes supplementary material /

Comprend du matériel supplémentaire

Pages wholly or partially obscured by errata slips, tissues, etc., have been refilmed to ensure the best possible image / Les pages totalement ou partiellement obscurcies par un feuillet d'errata, une pelure, etc., ont śté filmées à nouveau de façon à obtenir la meilleure image possibie.

Opposing pages with varying colouration or discolourations are filmed twice to ensure the best possible image / Les pages s'opposant ayant des colorations variables ou des décolorations sont filmées deux fois afin d'obtenir la meilleure image possible.

This item is fiimed at the reduction ratio checked below /

Ce document est fiimé au taux de réduction indiqué cl-dessous.

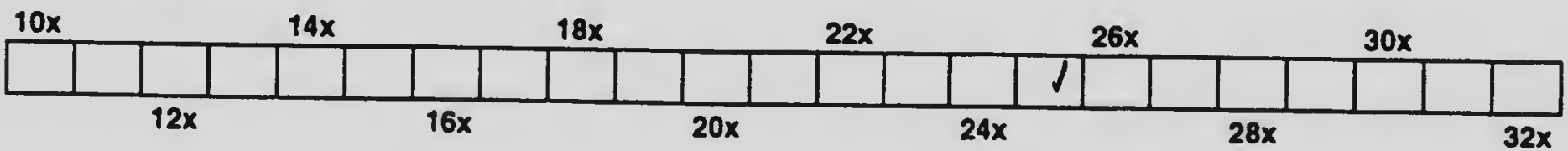


Tha copy filmed here hes been reproduced thanks to the generosity of:

\section{Library}

Agriculture Canada

The imagas appearing here are the best quality possibla considering tha condition and legibility of the original copy and in kaeping with the filming contract specificetions.

Original copias in printad paper covars ere filmed baginning with the front covar and ending on tha last paga with a printad or iliustreted imprassion, or tha back cover whan appropriate. All othar original copias ara filmad baginning on the first page with a printed or illustretad impression, and anding on tha last page with a printed or illustrated impression.

Tha last racorded frama on each microfiche shall contain the symbol $\longrightarrow$ (meening "CONTINUED"), or the symbol $\nabla$ (meening "END"), whichavar applies.

Maps, platas, charts, atc.. mey ba filmed at differant raduction ratios. Those too lerge to be entirely includad in one exposure ere fiimed baginning in the uppar laft hand corner. left to right and top to bottom, as many fremes as raquirad. The following diagrems illustrete the mathod:
L'exempleire filmé fut reproduit grâce de le génoros tó de:

\section{Bibliothique \\ Agriculture Canada}

Las imegas suiventes ont bt6 reproduites evec le plus grend soin, compte tanu de le condition at de le nettet' de l'exempleire filmb, et en conformitל ovac les conditions du contret de filmage.

Les exemplaires origineux dont la couvarture en pepier ast imprimbe sont filmb́s en commençant par le premiar plat et en terminant soit per le dernidra pege qui comporte une empreinte d'impression ou d'illustration, soit par le second plat, seion le cas. Tous les autras exempleires origineux sont filmés en commençant par le pramiore paga qui comporte une emprainte d'imprassion ou d'illustretion at an terminant par la dernibre pege qui comporte une talla empreinte.

Un des symboles suivants apparaîtra sur le dernidre imege de cheque microficha, selon le cas: le symbole $\rightarrow$ signifie "A SUIVRE". ie symboie $\nabla$ signifie "FIN".

Las certes, planches, tebleaux, atc., pr uvent etre filmos des taux de róduction différents. Lorsque ie document est trop grend pour etra reproduit on un saul clichs, il est filme partir de l'engle superieur geucha, de gauche droite. et de haut en bes, an prenent le nombra d'iriages nécessaire. Les diagrammas suivants illustrent la methode.
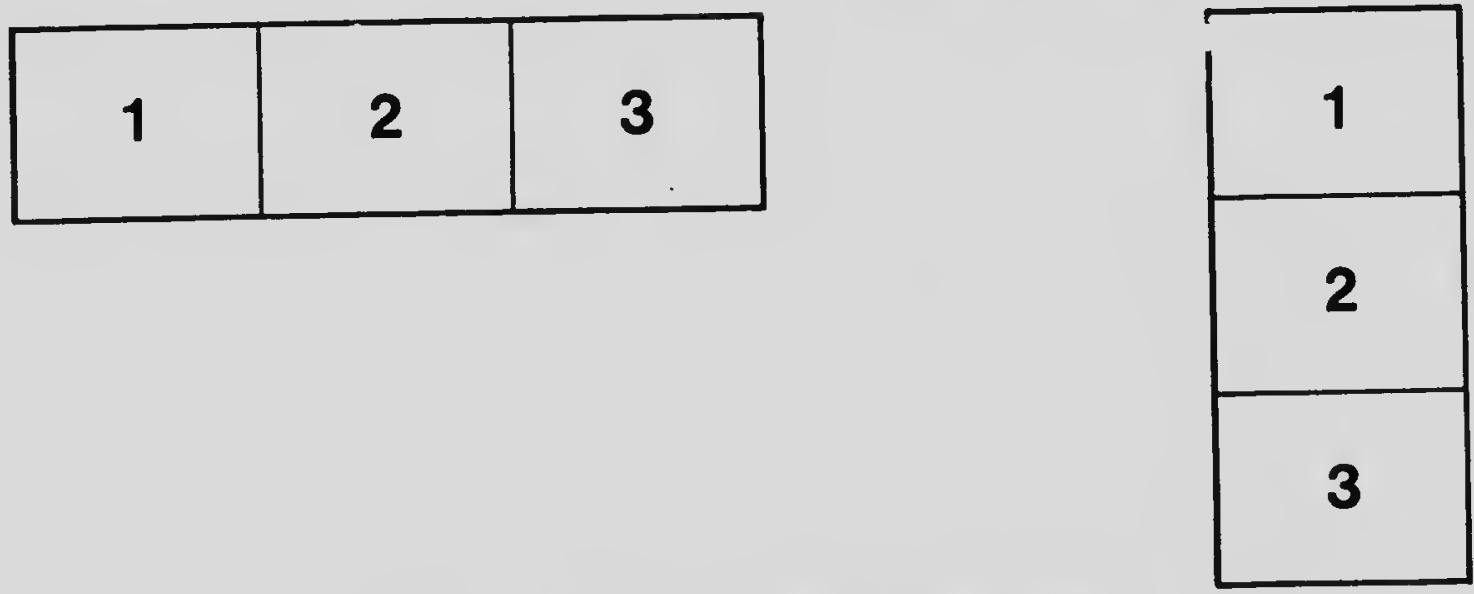

\begin{tabular}{|l|l|l|}
\hline 1 & 2 & 3 \\
\hline 4 & 5 & 6 \\
\hline
\end{tabular}


(ANSI and ISO TEST CHART No. 2)
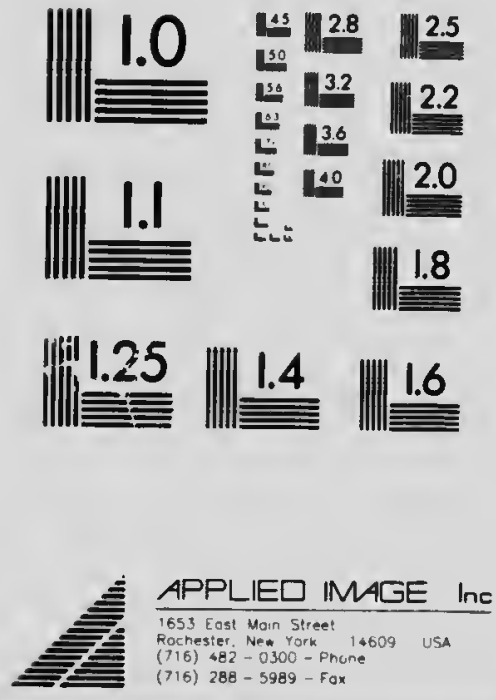



\section{DEPARTYENT OF AGRICULTURE \\ CENTRAL EXPERIMENTAL FARM \\ OTTAIVA, CANAIA}

\section{PLUM CULTURE}

AND

DISTRÍ́T LISTS OF PLUMS SUITABLE FOR 0NTARIO AND QUEBEC พITII

\section{DESCRIPTIONS OF VARIETIES}

BY

$$
\text { W. T. MACC UN }
$$

Borticulturist, Central Experimental Farn.

BULLETIN No. 4.3.

\section{JULY, 1903.}




\section{TABLE OF CONTENTS.}

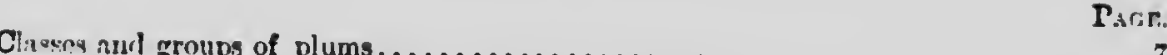

7

Plum culture in the provinces of Outisrio and Quebec................ 11

lixperiments with plums at the Central Experimental Farm. ............ 11

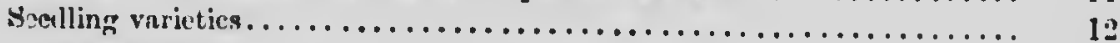

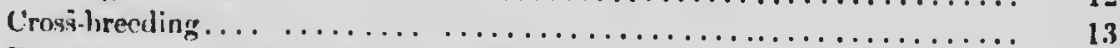

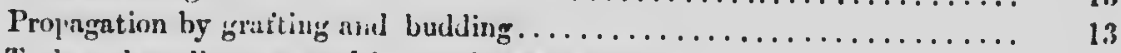

Tir.ls and applicances used in pruning and grafting.............. 13

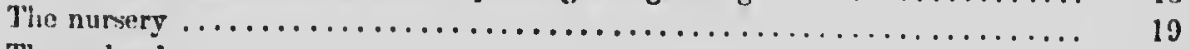

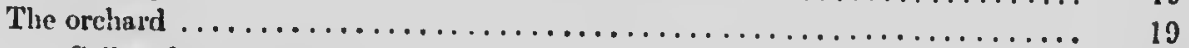

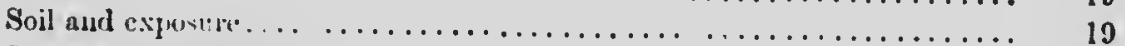

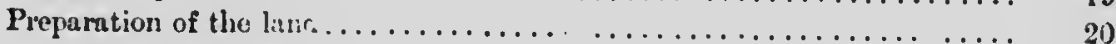

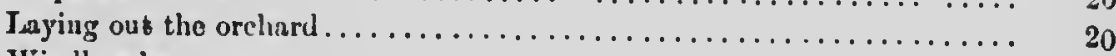

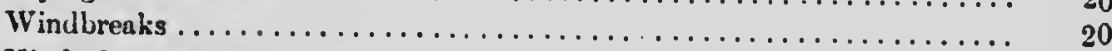

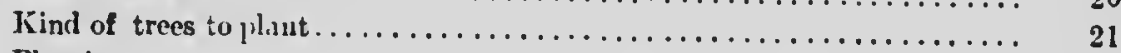

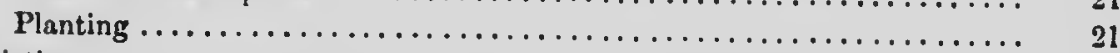

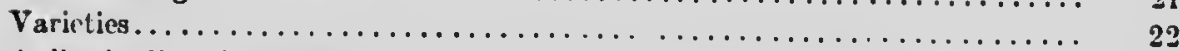

A district list of varieties for the provinees of Ontario and Quebec.......... 23

Deseriptions of varieties . . . . . . . . . . . . . . .

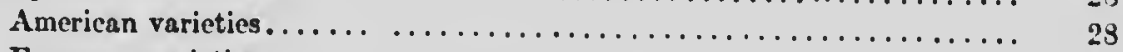

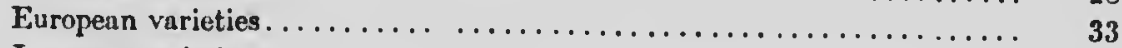

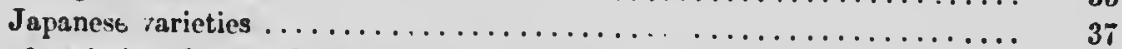

I.ist of varieties of plums being tested ut the Centr. speruncutal Fium..... 33

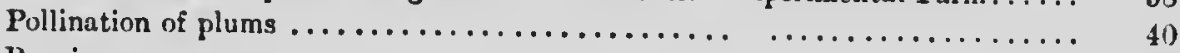

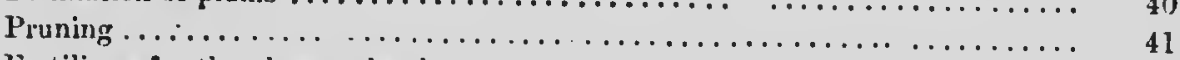

lertilizers for the plum oreliard $\ldots \ldots \ldots \ldots \ldots \ldots \ldots \ldots \ldots \ldots \ldots \ldots \ldots \ldots, 41$

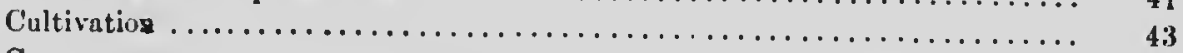

Cover crops....................................... 43

Picking, packing, sturing und marlketing the fruit.................. 44

Cinning and prescrving American plums...............

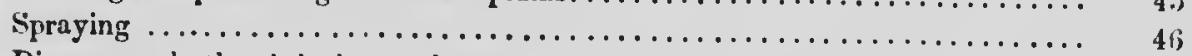

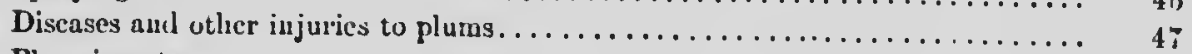

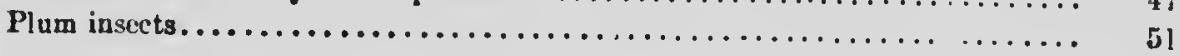




\section{To the Honouralilo}

The Minister of Agricultura.

814,--I beg to sulumit for your approval Bulletin No. 43 of the Lixperimertal Farm series which has been prepared under my direction by Mr. W. T. Macoun, llorticulturist of the Central Exprerimental Farm.

The sulject treated of is Plum Culture and the mformation presenterl has been largely derivel from the experience gained in eonnection with plum growing at the Central Experimenta! Farm during the past fiftecn years. In this bulletin information is gircn as to the best methocls of preparing the suil fur a plum orchurd, with particulars also ns to the planting and sulseequent care of the trees. Instructions are also given as to methods of pruning, grafting and on many other topics relating to this branch of fruit industry. Lists of varietics of plurns suituble for planting in different parts of Ontario and Quebec are given with deseriptions as to the character, quality and time of ripening of each sort. Some of the diserses to which the plum is subject are also referred to and methods of treatment suggestel.

A brief acconnt is given by Dr. James Fleteler, Entomologist and Butanist to the Fixperimental Farnis, of some of the more inportant insects which are injuriuus to the plum. A chapter lias also been prepared by Mr. F. T. Shutt, Clicnist to the Furms, on fertilizers for the pluni orchard.

It is hopel that the information submitted will be uscful to those interestel in the cultivation of this fruit in Canadn, that it will prove a stimulus to the further llanting of plums and that it mny aid in making the growing of this useful fruit more sucersiful and more profitable in this country.

I have the honoul to be,

Your obedicnt crvant,

WM. SAUNDERS,

Ottawa, July 24, 1903.

Director Esperimentul Farms. 
. 


\title{
PLUM CULTURE:
}

\author{
BT \\ W. T. MACOUN, \\ Ilorticulturist, Central Experimental Fi ,., $\therefore$ usca.
}

If every menber of every family in Canada had a plentiful supply of plums of the $\therefore$ it quality for home use, and if enough of this fruit were exported profitally from ' unmia to supply the demands of the people of other larids, there would he less necessity for writing a bulletin on plum culture. But unfortunntely this is far froun locing the reality. Comparatively fow people get good plums to eat, especially in the fresli condition, and the export trach in plums, whatever it may bo in the future, is still in its infancy. The past experience las been that the consumption of fruit incrensen almost or quite as rapidly as the supply, providing the latter is properly distributed, and it is not too much to expect that it will do so in the future, at least fol some time. The desire for fruit grows on the consumer, and the better the quality of the fruit supplied the grenter will bo the desire for it.

In order to make this bulletin on plum sulture as complete as possible, it has been necessary, in ruldition to using tire information obtained from experimental work here, to correspond frecly with fruit ga owers and to consult many publications and thus get the

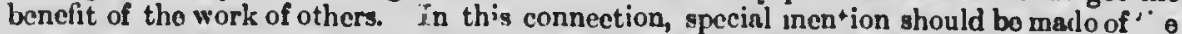
recent wcrk "Plu. and Plum Cul" "r "Prof. F. $\Lambda$. Waugh, from which practical ad useful book many sugbestions have 1 obtained and serernl descriptions copied. To Canadian fruit growers I am especia " indebted for information regarding varieties and for specimens, ns well as ass 'tince in preparing the district lists. In this respeet I wish to refer particularly t', Mr Auguste Dupuis, Director of tho Quebec Fr it Kxperiment Stations, Village des Aulı:3ies, Que, who very kindly sent ne a largo collection of liuropean pl, ".. grown ils .. " tistrint, and who gave me very full information regarding the culture 0. $\therefore$ fruit tirese .nd elsewhere in the provinec of Qucbec. Horticultural workers in tis United Strtes lave also been very courteous and have given me much information, especially in reference to the newer Ainericnn pluus.

I desire to gratefully ackuowledgo the assistance of $D_{1}$. James Fletcher, Entomologist and Botanist of tho Dominion Experimental Farnıs, who prepared the article on "Plum Insects," and I am much indebtod also to Mr. F. T. Sliutt, Chemist, for the chnpter on "Fertilizers for the Plum Orchard."

Some of the matter reiating to pr paration and culture in this bulletin has been t.l.en from bulletin No. 37 on apple culture by the writer, but changes have been made in this where necessary.

'The plum has been eultivated for a very long time, and the origin of the older varictics, like the apple, is unknown.

There are three great classes of plums from which are derived most of the iltivated varicties of to-day, namely, the European, derived from Prunus dom ica, the Japanese, and the Ar rican. 


\section{EUROPEAN PLUMS.}

This class of plums has reached a higher stage of development than either the Japanese or American, which is due to the fact that they have been under cultivation from very early times and that more systematic and intelligent labour has been spent on their improvement. It is thought that many of tho European plums have gradually develuped from the Damson, and thit the latter originated from the Europ an sloe, l'runus pins? The Damsons, however, are so distinet in tree and fruit from other European pluns that some authorities make a separate group of them. Thero is such a wide difference between the Damson and tho Reine Claude or Green Gage groups that it seeins reasonable $\omega$ suppose that the origin of the two was differcnt, and indeel thicy havo been regarderl as different types, at least sinco tho Middle Ages. Buth the Dumsons and the Green Gages come fairly true from seed. In his book on "Pluns and Ylum Culture," Prof. F. A. Waugh, who has made a thorough study of the Europcin plums, after making a separate class of the Damsons and a group of the Reine Claucle or Green (iares, diviles the other varicties into several types. This division is valualule and is adopted here. Tho varieties described in this bulletin being mostly given as repieientatives of these tpyes.

Dame Aubert type.-This includes the largest European plums and is represented by Yollow Egg, Golden Drop, and Grand Duke.

Prunes.-_Represented by Fellenberg (Italian prune), German Pruno and Raynes.

Perdrigons.-The only variety of this type which is grown in Ontario and Quelece, to the writer's knowledge, is tho French Red Perdrigon, introduced by the Trappist Fathers, Oka, Que.

Diamond T'ype.-This includes some of tho most productive, firmest and lest shipping varieties and usually those of only medium quality. Varieties of this typo aro Diamond, Kingston, Qưckenloss, Glass, Shipper, Mnunt Royal and Arctie.

Bradshaw Type.-Under this type Prof. Waugh ineludes Bradshaw, Victoria, Pond, Field, Duane Purple, Oswego and Giant Prune. Theso varieties, however, have unt as niany characteristies in common as those of the previous types.

Lomburd I'ype.-Represented by Lombard, Communia, Voronesh 20 of Burll, Ieipsic of Budd, Prince of Wales and Merunka. The Early Red Russian and White Nicholas of Budd would alsn be ineluded in this type.

Damsons. - The best known varieties of this class are Shropshirc, French, Frogmore, and Cluster.

leine Claude or Green Gage Group.-There are a large number of fine dessert varieties in this group, the priucipal being Bavay, Green Gage, Iawrence, Impcrial Gage, McLaughlin, Jefferson, Washington, General Hand, Bleeker, Peter's Gage and Qucen May. Pluns of the Furopean class succed best in Ontario in the counties bordering on the great waterway southward and eastward from the Georgian Bay to the Thousand Islands. They may be grown very successfuly all through sonth-westcin Ontario and the Niagara peninsula, and through the central counties to those borlering on Inke IIuron. East of 'Toronto the best varieties are grown within twenty five or' thirty miles of Lake Ontario. North and east of theso arcas only the hardicst kinds sueceed well, and but very few are hardy north of latitude $45^{\circ}$.

In the province of Quebec a few varietifs give fair satisfaction in the Eistern fownships and a few on the Island of Montreal, and along the Ottawa above Montrial, past the Lake of the Two Mountains. Along the south shore of the St. Lawrence, below the eity of Queber, in the counties of Livis, Belleclasse, Montmagny, L'Islet, Beauce, Kamouraska and 'Temiscounta, nud along the north shore in the counties of Portneuf, Quebce (Island of Orleans, cspecially), Charlevoix, nost of tho finest varieties of Europenn plums can be grown with goo' success. It is, however, near the river, and where its influcnce is felt, that these plums suceed be'st.

The hardincss of tho liuropenn plums appears to bo governed partly by the nuisture of the atmosphere, and partly by tho temperature. It Ottawa very few varieties will fruit at all, and most of theso only bear a goul crop onco in three or four yenrs. It is not the wood which is killed by winter, although winter killing of tho tips does 
oceur, but the flower buds are destruyed. This killing of the buds appears to be due partly to the dry, cold weuther of winter, and pertly to spring frosts. Good erops of than $20^{\circ}$ becums have been produced at Ottawa after tho temperature had been lower anse of failure. Along the south winter, showing that temperature alono is not the where the temerntung the south slrore of the St. Iawrence, below the city of Quebee, of liuropean plums are reurularly grees Fahr. below zero, gool crops of the best varieties prolueerl. The moisture of the uir in this ease appears "lhere is it igent diftiservation of the flower buds, even though the temperature is low. lime: seedlinen: may erence, however, in the harliness of tho diflerent varieties, and in colecest temperatures produced which will lave flower buds eapablo of surviving the

JAPANESE PLUMR.

Owing partly to their novelty, partly to their vigour, prokluetiveness and good shipping qualities, and partly to the way they have been boomed, the JapanAmericis lave been widely planted on this continent. Altlough introduced into Europan. The oricin of this elass of plum is now almost as well known as the mative of Clinn. Thanese plum is unknown, but it is thought to be a when the plnus The Japanese were not very systematie in their nomenclature, and Ther lhere was grent eonfusion of names. able kinds can now been pretty well worked out, and the best known and most profit. United states anc a a my seedlings have been grown in the

Wherer of hybrids originated, some of whieh have grcat merit. goorl, and a still most of the varietics is only medium in quality : a few, liowever, arc and good keepin sulaller number very good. 'The productiveness, firmness, appentance Japinese plums qualities arc what make these plums valuable. The majority of the but a few secul to be quite as hardy in the flower bud as the hardiest of the European, more likely to be injured by spring. They bloom very early, and on this aecount are

The simon or a crosts. (n) some of its chirracteristics and may be classed with the Japanesc plum liere. This plum is thoughit to be a native of China and was introduced into America from lirance about muwn in the United lias not been planted to any extent in Canada, nor is it willely sume, thourh in the is productive and the fruit is and liand. ships well. It deros in quality. The tree is quite probluetive, and the fruit keeps and ships well. It dues not appear to be any lardier than the Japanesc plums. It has been grown with success in south-western Ontario, but is not a desirable plum to plant.

\section{AMERICAN PLUMS.}

These plums late a wirle range on the American eontinent, leeing found wild from Mexico nortlı to the provinee of Manitubi, and from the Atlantic to tlic larcific oceans. They are represented over this great area by seven distinct species and six recognized groups or types. Of these, the eultivated rarieties originater from

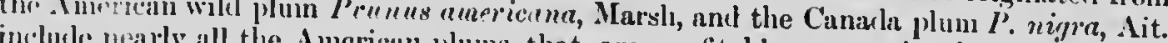
inclufle nearly all the American plums that are profitably grown in the provinces of Ontario and Quebee. The inore southern groups, of which a fow varieties are partinlly suecessful, are: the Miner group, P'runus hortulane mineri, Bailey, which is closely re-

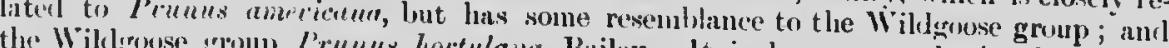
the Wilkense group P'runus horfulame, Bailey. It is, however, only in the milder jarts of the proviace of Ontario that they are even fairly satisfactory. At Ottawa, the flower buds are injured and the crop light. The varietice of the Wayland and Chicisisen

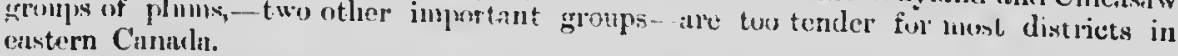

Amerireme Group.-This group has, up to the present time furnisher the best vinicties of American plums. The range of Prunus americana is given by Wingh as being New Jersey and Ohio to Mimmersuta, Montana and Colorado. 'The tree is a 
spreading grower, sometimes reaching a height of 20 feet. On aceount of its spreading liabit the trunk anl large branches are often split or broken by wimls when l:aden with fruit or by henvy snow storms in winter, and this is a serious draw-

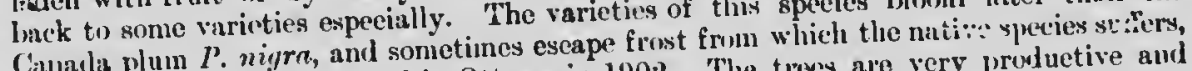

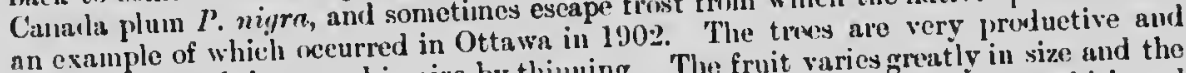
an example of whech improved in size by thinuing. The fruit varies greatly in size and the the fruit is much im yellow to red. The skin is generally tough, and often thick and colour langes from yellow to the firm or moderate'y tirm, very juicy, sweet, and someastringent, but the thesh is usun. The stone usually elings, but icensioually is almost or times ribh and high thaoured. On this tres is found thrivine best in rich and rather

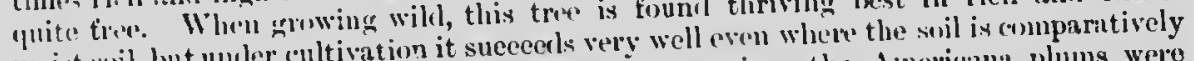

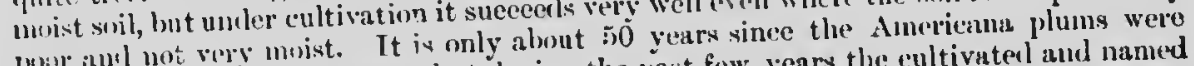

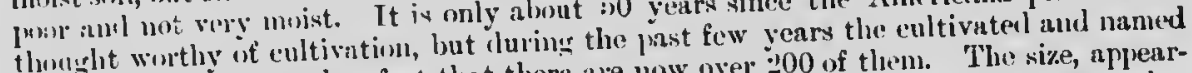
thought worthy of entes fore fint that there are now over $: 00$ of them. The size, appear-

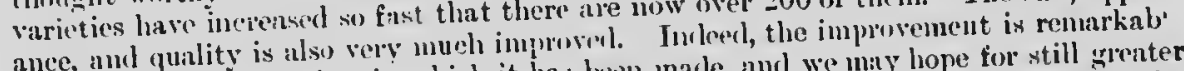
ance, and the short time in whieh it has bren inarle, and we mily hope for still grenter considering thement yot. The appeianee of the plums is all that enulil be desired, and the best vinieties are almost large enough, but there is great room for improvement in the character of the skin and thavour of the fruit, although the latter is goorl. larlier varieties are also wanted. The present fruitins season of the Americana plums at Ottawa is from the fourth week of Aurust until alsout the last of September. Somo varieties of this group are Bixby, Wolf, Hawkeye, Stenldarl and De Sisto.

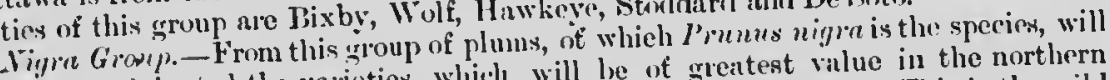
probably be miginated the rarieties which will he of greatest value in the northern pirts of Ontain, and the coldest parts of the provinee of Queber. This is the wild plum of Cimadia, having a range from the Maritime Proviuees west watd and north ward to Assinibuia. Although in some places this species ean searecly he dheler parts of the

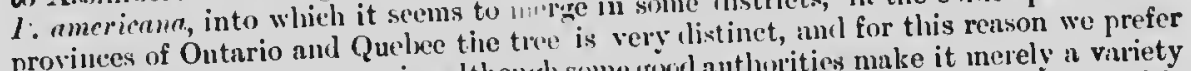
provinces of Ontario and ducies al though some grock authorities make it merely a variety consideriay it a separte It a more upriglit arower than $l$. amerireme and the wool is

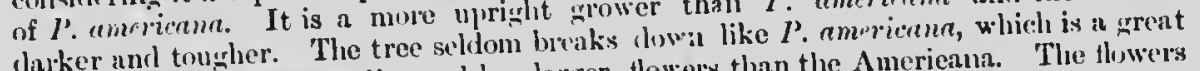
aliantage. It bloms earlicer and when opening. The fruit ripens early, and on this also have a pink tinge, espechafible, as it can les marketed when there is little eomaccount is sometimes more penthogh the namel varieties which are now non the petition with wther pho quality us the brst of the Anericana group, some of the wild

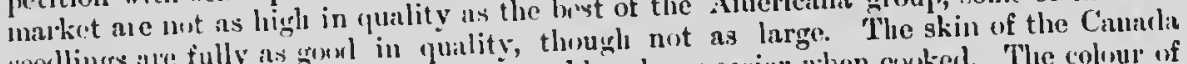

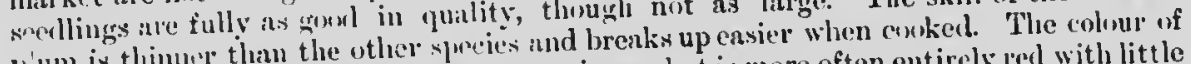

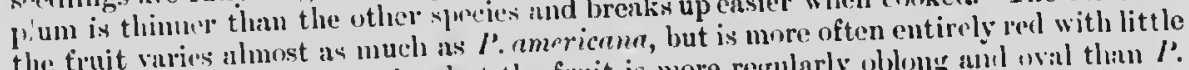

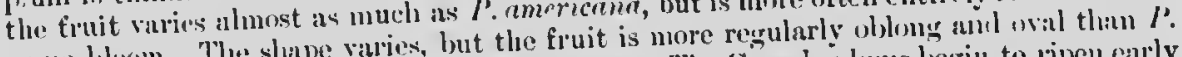
or no hown. The shape valles, like that species. The Canada plums loegin to ripen carly

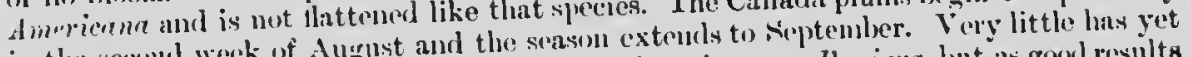

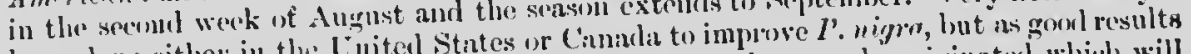

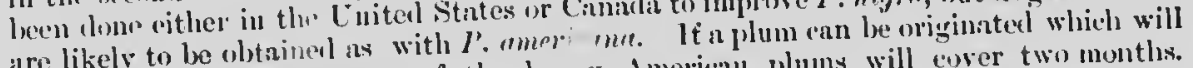
are likely to be obtained as with the has $y$ Amerienu plums will eover two months.

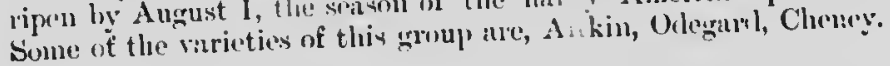

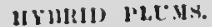

Duriug the past ten year's a numler of hybril plums have lexell placed upon the market. Jlast of the more prominent of these wore originated by Iouther Jurbank, of Califorula, who has devoted much time to this work. Fow of his hybrisk, however, which are now on the market will be likely to prove valuable in the colder parts of Ontario and Quebere, as the parents of most of them are valieties which do not prove suecessful where the elimatr is severe. Some of them maly be of value in the wiblner parts of Ontario where the Japantese plums do well. 
Thern is a wide field for work in plum hybridization. If blood of the European and Japanese varieties can be introduced in the Americanas and Nigras and the hard. iness of the latter maintained, plum culture in the north will reecive a grent impotus.
It is not too mucli to hope that this will soon be accomplislied.

\section{PLOM CULTURE IN THE PROVINCES OF ONTARIO AND QUEBEC.}

The plum las lreen most largely planterl in the Ningarn peniusula, where it grows to perfection. From Ilanilton to Ningarn, orchard after orchard of this fruit may be seen, and in the spring when in full blowu and in the autumn when larlen with fruit the trees ale a siglit to beholel liat plun growing is by no menns confined to tho Ningara district. All throught Suuth-western Ontario and alon's Iakr Huron alld the fieorgian Bay, plums suceed woll and are grown in large quantities. Inded, the Georgin Biy distriet appears fuite mpual to the Niatsilm peninsula for plum growing. Plums are also wrown very succe:ssfu'ly from Hanilton eastward within thirty miles of Iake Ontario and the St. Lawence River, to about the sity of Kingstom. Some of the best plunis also succeod in tle midland rounties of Ontario. Fortl and east of the districts inentioned, plum growing is confined manly to the Amerieana and Xigra var.

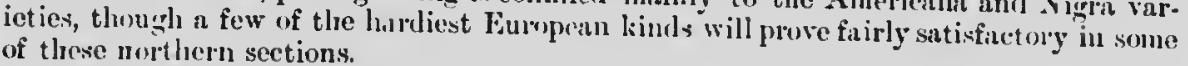

In the provinee of Qualue plums are not grown to a very liarge extent, although in s'me parts the best luropein plums a: an be grown very surcissfully. On the Island of

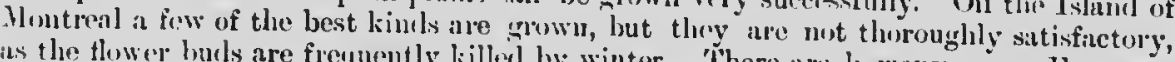
is the flower buts are frequently lilled by winter. There are, lowever, some Furopein serllings origrinated on the islanl which give goorl satisfiction. The best district for growing the European plums in Quebee is probably along the south shore of the st. Iawrence, Inlow the city of Quelsee in the counties alrearly mentioned.

Ifere even the more tender lumpan kinds appear to do well, and M1. Dupuis in. forms the writer that the som bogn bins in the first loalf of August with Farbite and

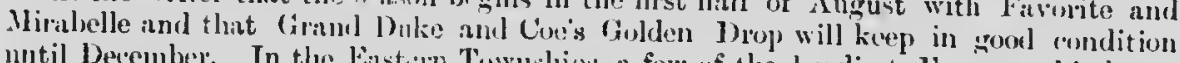
mitil Deember. In the linstin Townshiph, a few of the hiordiest burepean kinds are f:tirly sitisfictory, lout tha elinate is tuo severe to grow them protitably on a lirge

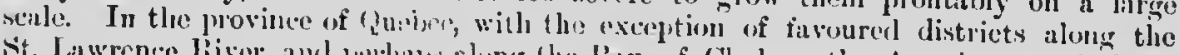

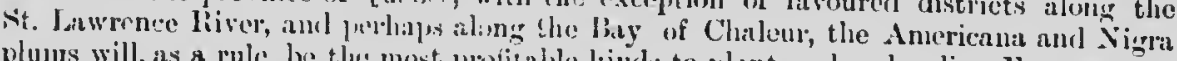

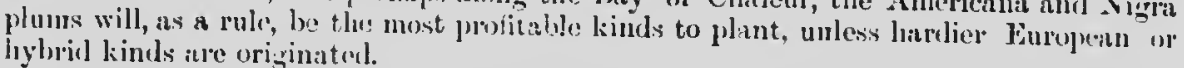

The profits from flum growing lave loren good in the past, lut such grent numleris af trees liave lom planted in mernt yours that unless a linge pirt of this fruit can be

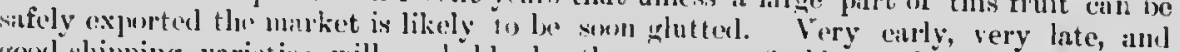

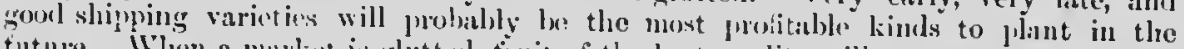
tuture. Whon a mirket is glutterl, find of the lxest quality will command the highest prices, provided it is in gonl comblition and of tine appealance, and this fact should ilsu be taken into consilication when planting.

\section{EXPERIMENTS WITH PLUMS AT THE CENTRAL EXPERIMENTAL FARM,}

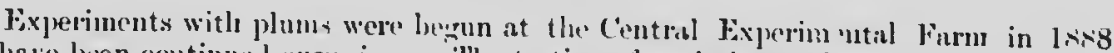

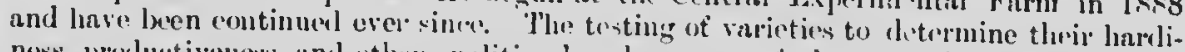
ness, proluetiveness, and other qualition has locen one of the mont inportint experiments, and al large: number of villiet ies have been testerl. Biperiments liave also been

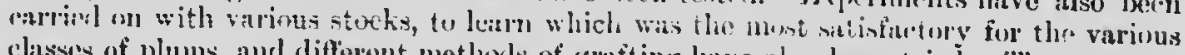
classes of plums, and different methorls of grafting litwe alsu lesen triel. 'The spraying of the trees witl various mixtures and solutions to control fungeus disenses and insect pestes lass also been an important part of the work. Ciuretul recorls hase been k'pt of the dates of blowning of the diflirent varieties, and the information thus obtained is 
very useful, as it las been proven that few varieties of American plums are self-fertile, and it is thus necessary to have, in most cases, some other kind bluoming at the same time in order that fruit may set well. A table showing tle blossoming period of the different varieties will be found in this bulletin. The yields from each is bearing plim tree are kept separate, and it is thus possible to tell whether oninating seenling plums, than another. Much work has been done in testing and of cspecially of the Amcrican varieties, and a fow also becn carricd on.

Sumc experimental work in cross-breeding huitable for plum growing as it might he,

The soil in the plum orchard in mons ared. The trees werc originally $20 \mathrm{by}$ being a light, sandy loam, but good plus carried on and the trees are now 20 by 10 20 fect a part, lut interplanting lias been the orcharl, consisting of 459 trecs of named feet apart. There are now 565 trecs in there are a large number of seculings planted 10 by 10 fect apart.

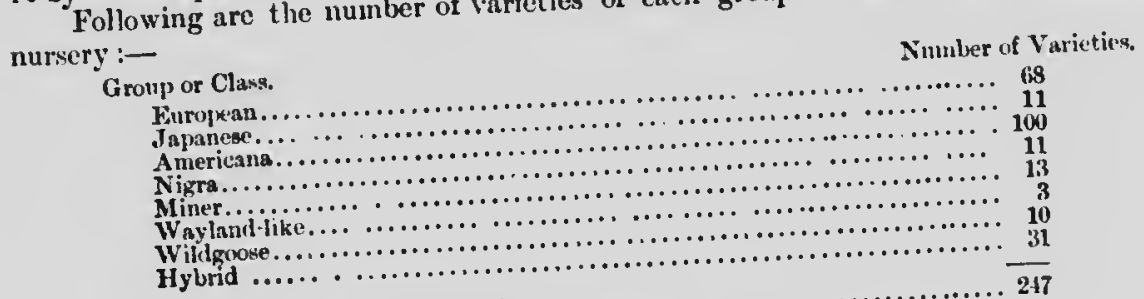

'Total varieties.

\section{Seedling Varieties.}

While there are many fine named varietics of plums which sureceel in the more favourable parts of the provinces of Ontario and Quebec, there is always the possibility of getting something better. In the colder parts of the provinces where few of the better plums succeed, there is a fine olportabing new varieties is by growing seellings from the stones of the best plums which have ripened in the district where new kinds are dcsired, and if no plunss have yet been grown there stones should be procured from the nearest place where they can $1 \%$ obtuined. The European plums have been improved for so nany centuries that it will be dithicult to olstain a seelling plum of this group which will be letter in quality than the best now in cultivation, but the prospects for

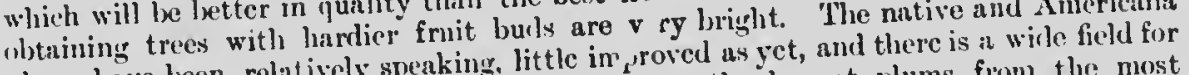
plums have been, relatively speaking, littic in roved the largest plums from the nost development here. Stones should scellings are desirel. These stones should, when prosible, be planted immeliately after the fruit is ripe, as if the stunes become diry they will not germinate as well, and sometimes will not grow at all. If they are planted at the time the fruit is ripe it is not necesary to remove the pulp. If the stones cannot lhe comeniently plantel at this time they slould not be allowed to become dry. They nay be kept over winter in boxes mixed with sand, which should be moist lint not wet. $A$ layer of sant about onc inch in thickness is gnt in the bot tom of the lox and is mere. coverel with a layer of stones, the latter are then hox is filled. This is alled strititienlafer of stones spreal on top, and so n: whthe there is good drainge and no danger tion. The box slould be buried outsinle whe the stones freeze when they are thus moist from small animals, or kept in a cellar. He the ster in the spring, but there is a danger

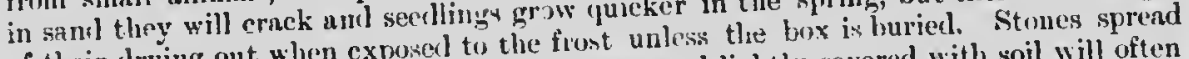
of their drying out when exposed to the flat and lightly covered with soil will often outsile in the autumn in a well dininge

The stones should be planted not more tlin one incli deep, (often they are planted two deep, ) ill gooxl loumy soil, in rows thrce feet apart and dropped from ane to two 
inches apart in tlue rows. These usually germinate in the spring, after which the soil should be kept thoroughly eultivated during the summer to induce a thrifty growtl. The apart or ten ly five foet aul ling, the young trees slould be planted out about ten sert Scions nay then be taken from to fruit, whirh they will do in from three to six years. the best of these will be likely to promising varieties and grafted. Stones planted from ling plums, (sipecially of the Am proluce sr mething still better. As many of the seed. the grouncl on which they are growing and native varieties are as guol as their parents,

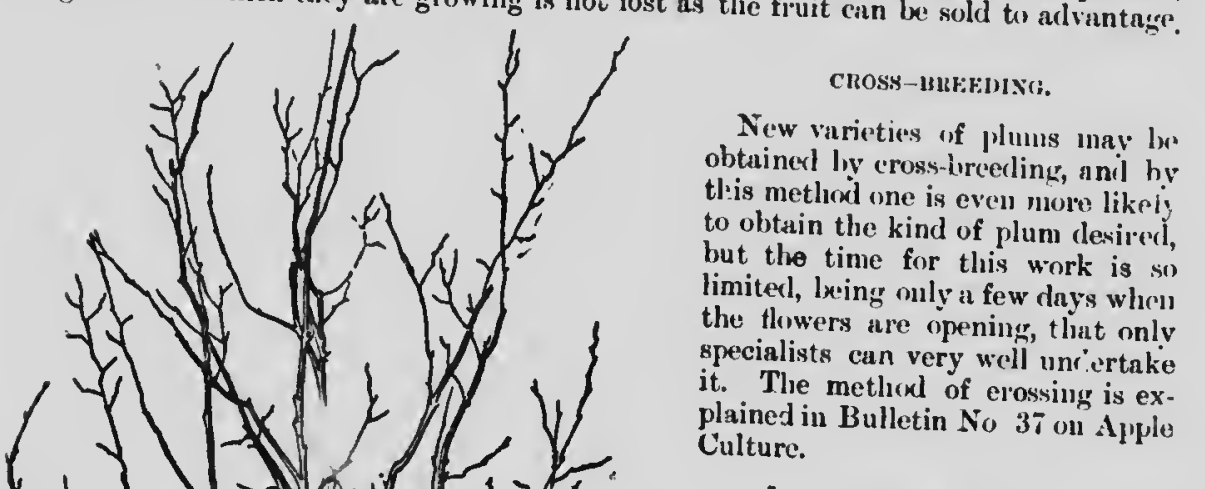

\section{Propagation.}

The plum is propagated principally by budding and grafting, althougli a few varieties will stıike more or less readily fron euttinirs, and some kinds when on their own roots are increased from sucker's.

sToeks.

While it has not yet been elearly. proven that the $\mathrm{s}^{\prime}$ " $\mathrm{k}$ on whicl. a srion is grafted will materialiy change the flawour a scason of the fruit, it does afficet the vigume aml

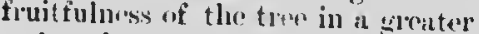
or less denren. It a seion is grafterl (11) a lwalf steck whe tree will be lwatred and will cone into bearing kinne than if grafterl on a thrifty sterch as anything which checks the growth of the tree promotes enty fruitfulnow. It is posisible, lowever, esprecial: top grofting, to lave such a s rowins stesk that the graft oul se it tom mueh and the tree lecomes top licary and if it does not die owing to a poor circulation of sap, the graft is liable to be brokens oft hy wind. The tree in the accompanying cut was killed beciuse there was not a iree cireulation of saj. The stoxk also, if it is tender, may be winter killed and

European plum top grafted on Nigra plum, three ftet from ground.

thee whicli iuny be perfectly hardy 
above grounci is ruined by being grafted on sueh a stock. Nurserymen find that the acion influenees the root system of the stock, but $i c$ is not so clear that the scion or graft makes the stock any larrlier.

If a cree is planted deep enough, roots may be thrown from the scion and the tree will eventually be on its owil r(x)ts but this should not be depended on as a rule, and a stork should be usel that will be harly, give a gond unim, and make $n$ thrifty trow.

The two main stocks used in grafting and budeling tho plum a" tise Myrolwhan and Mrrianna.

Myrobalun.-This is a Furopen plum and is inported prineipally from France. It unitew renlily with the seion and throws few suckers, which make it a very desurable stoxk, where the winters are not very severe. It is ased very genernlly in America, but more in tho morth than in the soutl: where the Marianna is ehielly used. The Myrobolan plun is not a satisfactury stock for the colder parts of Ontario and Quelece, as it is bialle to winter kill.

Mari. nur.-The Marianna plum is used largely in the Southes. Stutes is stoek, whre it propagiates freely from cuttings. It is thought to be a hybrid letween the Iroblolin and the Chickasaw plums. This, also, is not a desirable stox.k for tlie collule parts of Ontario and Quebee.

I H.w. The peach unites realily with the plum and is usel in the Uniter? sitates as a stuck for it. It can be gr wn cheaply, and strong young stoeks are reselily ohtinined for urafting and budding. It has, howrver, the disadvantage of not being latuly enumh in many parts of Canada.

¿. Julien.-The St. Julien is a European stock that is used to a limited extent in America for propasating the European plums, but the Yigrobolan and Miarianna stceks (an ho ointainel so rhereply that it is not used rach now. The St. Julien is, however, thr siffist stenck for lisuropean plums in the north.

Amorima and Vatiee.-. Imericana and Native plum seellings furuish the best stocks for the coller parts of Cunada. The young trees make strong grow th and are stocks for the colder parts of Canada. The
rery snitable as stocks for grafting and budding. This stock is not usually sativfactory
when the Juropean plums are top grafted on it, as the top outgrows the stoek and rither breaks off from being top lieavy or dies from lack of uourishment, as the native varietios, especially, grow much slower. No bad results, lowever, have followeml from ront arriting tho Furopean plums on Americana stuek, and good thrifty trees havo Wen obtuined but the trees ar. still young.

Sand Cherry (Prumus pumiln). - The Antericana plums lave been successfully root frafteal on the sant Cherry at the Fxperimental Furn, and trees which have leen enited 10 yours are still in goorl condition, with a perfect union and hearing well. 'l'he tries an cunsilembly dwarfell by this stock. The Sand Cherry may prove very useful Whe rowo planting is alupted, as many more trees coulu be planted on an acre when dwartel ly this scuck. Trees graftem on this stock, however, for tru years are nut as

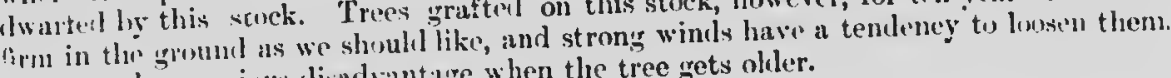
Ihin miag be a serious disadiantage when the tree gets older.

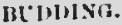

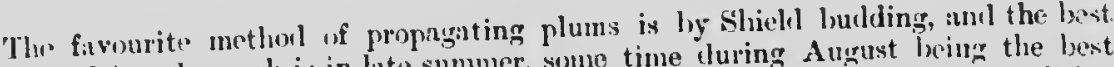
weron for doing the work is in late summer, sume time cluring August being the best timo in Ontario anl Quebec. At Ot tawa the trees have been fouml in goul romlitim

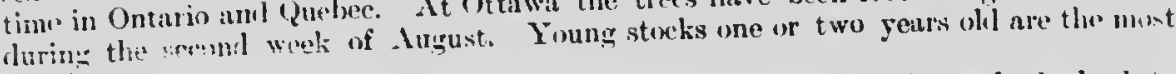
satisfactory.

Buhling is hest purforme? when there is still sutliciont sap beneath the bark to permit of the latter boing easily raisenl with a knife. On the other land, if the work $i$, dom. When the tree is still aprowing vigornusly the loud is liable to bo 'drowned out,' or, in other words, fonced out by reason of tom much sap and growth of the stuck. 
The stock whieh is to reeive the bud should be at least three-eighths of an ineh in diameter near the ground. The ower leaves are rubled off to a leis lit of tive ur six inches to enalsle the budder to work more freely. A perpendieulis cut is now marle in the stinck as near the ground as possible trom an inch to an inch and a-half longre and the sun on the north side of the tree, as the bud will not be so realily lried out by slond now that side. The cut should only extend through the bark. Another cut will appear thus: T

The buds are eut from ioll ileveloped and ripened showts of the enurent seasms forwth of the varioty it is desirm to proparate. Before the burls are removed the leave: should be cut $\mathrm{c}$.: the shoots; a piece of the petiole or leaf sten is left, lowever, by which the bud may be iandlecl after it lias been removerd. A very sharp, thinbarled knife is 11 seessary in removing the bud. Knives are speeinlly niarle for this

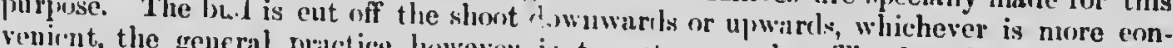
removel with the bul slouth lowerer, is to eut upwards. 'The length of the piece shankl le puite thin, as but little of the wheh long, and the cut surfuce smouth. It twige slonld be kept where the will worl is taken with tile bud. The buds or not ahy out while the work of buibling i's going on. The loud is inserter] muler the hark ly raising the latter with the binde of the knite or the pialt of the buthling knife made tor that purpose. The bud is then pusherl lown and unde. tise lark with the fingers, aurl finally the piece of leaf stalk which was left when it wats removed from the twig is peessed witl the blade of the knife to bring the loud into the proper position. The bark on enth side of the burl, which sionld uow be uniler the bark of the stock, will holl it in position. In mrler ti bing the bud and stack into rlose continet and prevent the former from sreviug up hefors the nnion takes phicee, they should be tionl tignlitly
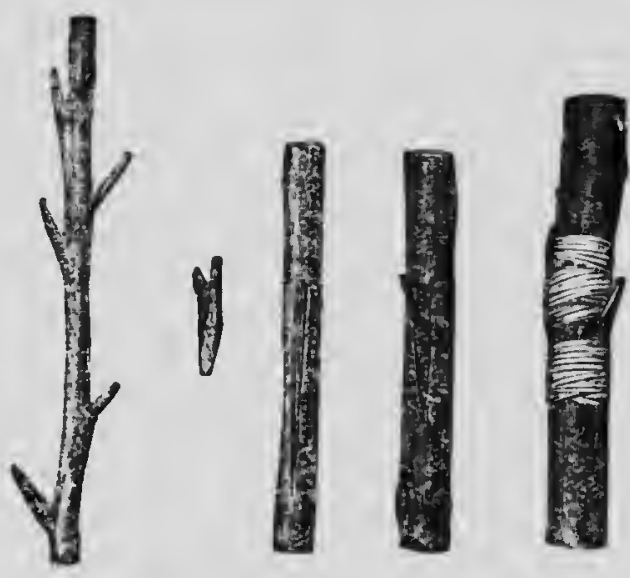

Eixiniple of Shitul-maliling. together witis rallia or sone sott stling, taking eare not to (ower the bud with it. The bud shonld unite with the strek in two or three wask, and after that time the striug shrukl be cut, as otherwise the burl may be injured. If the proper season bias been chosen for the work the burl should remiin dormant until the spring. It it starts in the antmur: it may be killerl duriug the wiuter. In the tollowing spring the stock shombl be rut ofl just abowe the buil which will rause all the strencell of the stock to

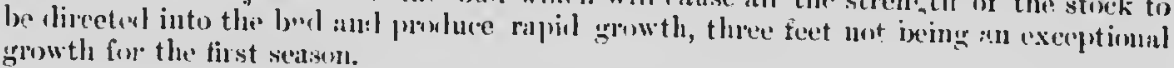

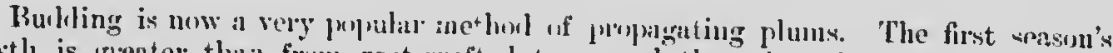
growtly is grenter than frim rout-arafted trees and there is a larger propuntion of

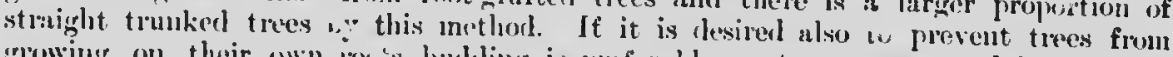
growing on their awn ire, 's, budling is preferable, as trees propagated in this way

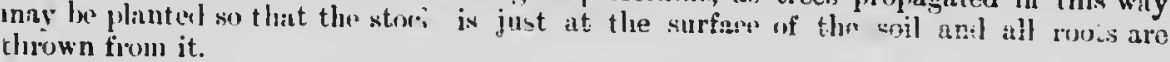

Buts may also be inserted in the branches of trees witl genol results. When the buds have united and grown the top may les shaped up as if top grafted. 


\section{GRAFTING.}

Scions. - As much of the suceess in graftin " depenels on the emolition and punlity of the scions, too much stress cannot be laicl on he importines of hiving them of the best quality and in the best conclition at the time of grafting.

scions may be cut any time nfter the woor is well ripenesl in the antunn and before the burls hegin to swell in the spring. The best time, howerer, is in the antumn,

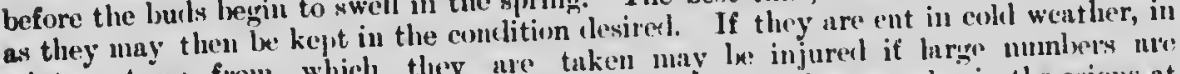
winter, trees from which they are taken split, there is less salp also in the serous at renover from them, as the bark is latble to spit, thenter than if they were cut in the that time and thus the chance of their trying up is ger whether the young wowl has been

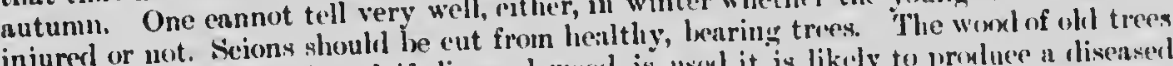

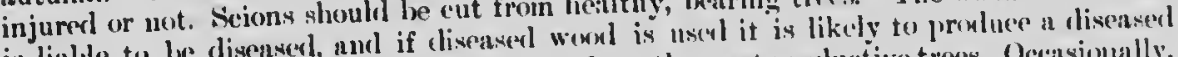

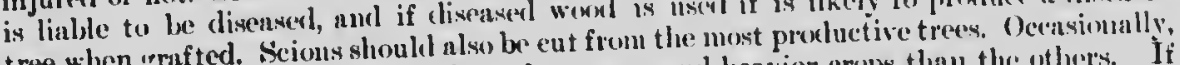
tree when grafted. Scions shoull will proluce more and heavier erops than the others. If me or more taken from these trecs, the probalility is that a larger proportion of the fred produce crops like the trees from which the seions were taken than grafter treswise would. The scions slould be ent from the womb of the eurrent sonson's arrowth, as older wood is not satisfactory. 'The buels should be well developerl and the wook thoroughly ripenerl. It is not wise to use the water sprouts or young sherts which spring from the inair branches or trunk for this purpose. 'They may not $x_{x}$ thoroughily ripened, and it is a lso possible that sproutiug proneusities may he thus murs developed in the grafted trees. 'The entire season's growth may le cut off und jackenl away until required for grafting, when it should be cut into jigeces tron fon to six inches in length having three well developed buts.

scions may be kept in good condition in moss, sitw-lust, sanch, or forest leaves. The last mamed are found very sittisfactory at Ottawa. 'These materials shoull be slightly moist, but not wet ; the object being to keep the seions fresh and plunp without there b.ing any danger of their rotting. They should be kept in a cond cenllar which is not too diry, and should remain dornunt until realy for use.

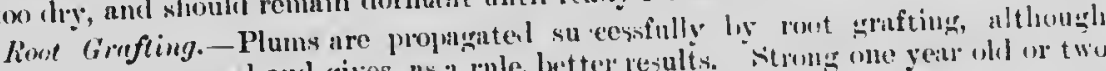

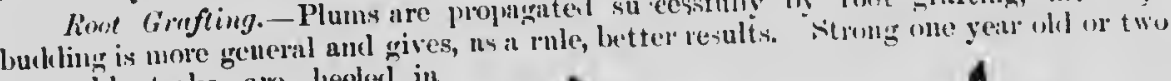
year olll stucks are leeblel in cluring the autumn in a eool eellar in moist sand. Grafting may le elome iny time during the winter, but it is usunlly not started until January or Fibliuary. Whip or tonge grafting is the metherl usually employed. As only the ruot is required, the trunk and branches are ent ofl and thowen away. As there is but little ulvantuge in using the whole ront, it masy lo divicked into several pirces, much deprouling oll its size. Barcl picce should be at least four inclies lon: 1 -momtl, sloping cut upwarls, alwut two inches long, is nuade acress the main pourt of 1 hes rost most suituble to recrive the scion. The seion is prepared by cutting off a pieec of the werol prosured for this purpose in the autumn from tonr to six inches

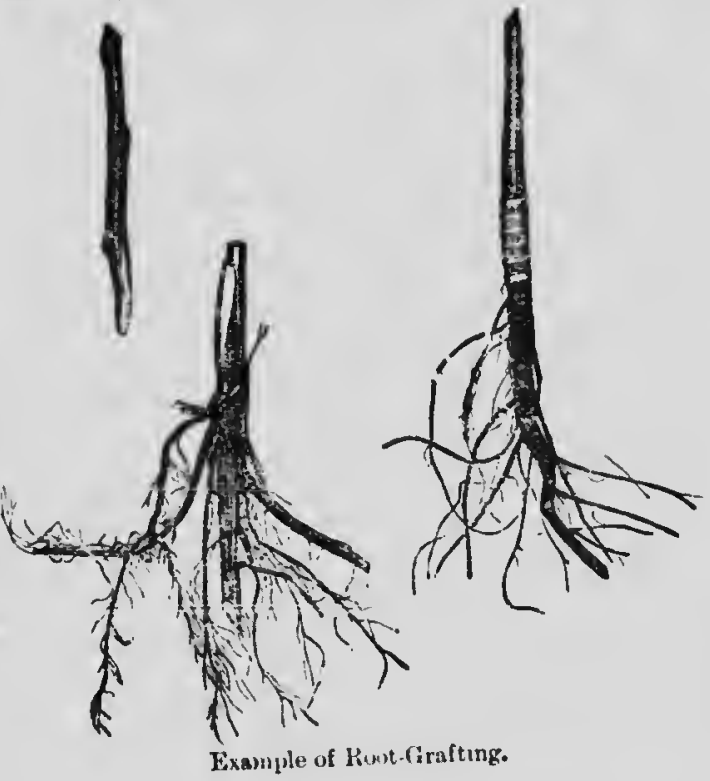
lon: $11 \ldots 1$ with about three well 


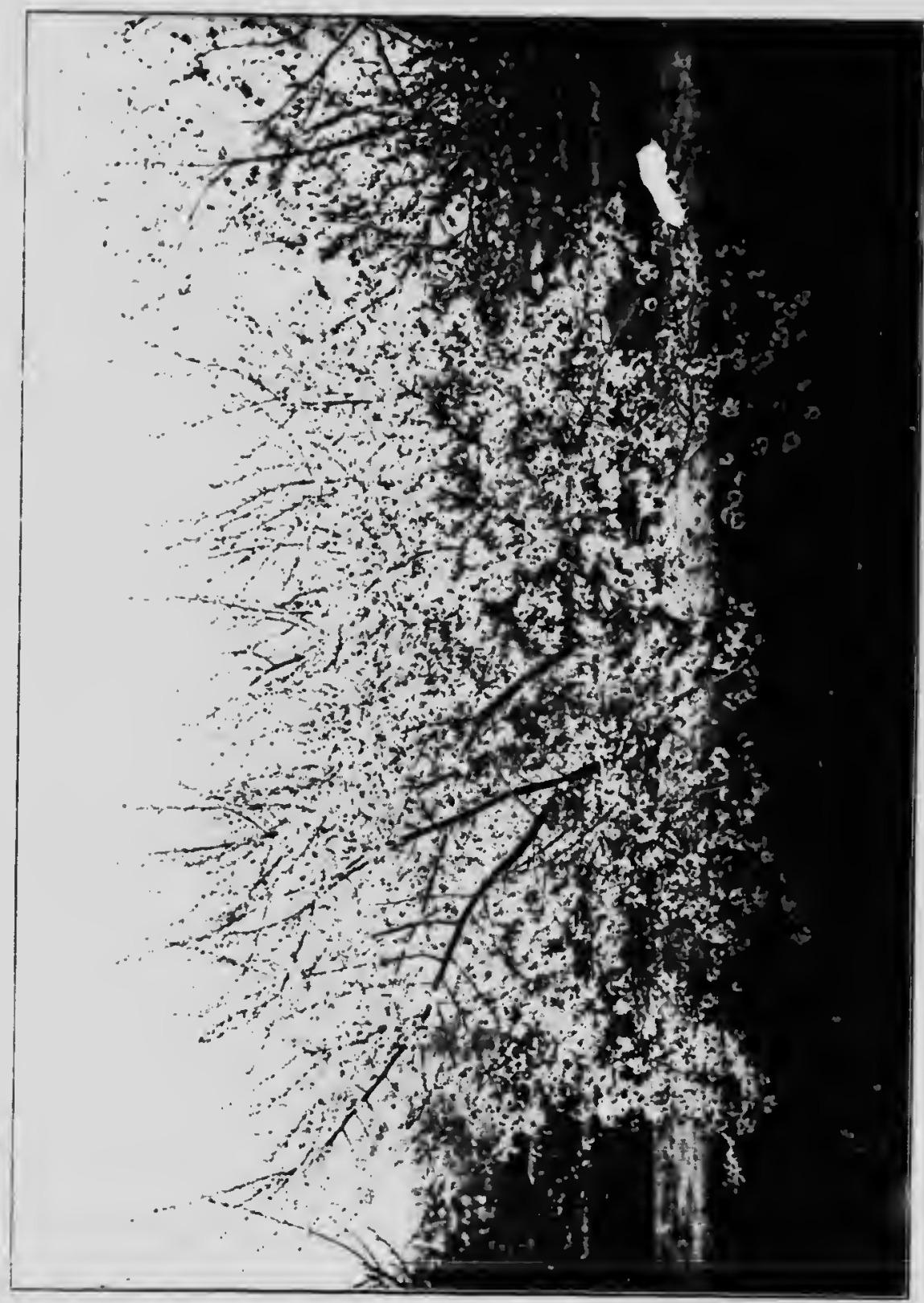


dev. "hed buds on it ; a mooth, sloping cut downwnrls and across it is now rmale of about the same length as that alreuly mude on the stock. Clofts are now makh- in the sloping surface of both scion and stock, in the former, upwards; and in the latter down warls. They are then joinel tog ther by forcing the tongue of the scion into the eleft of the stock. The inner bark, or eambium, of both scion and stock, slrould 3 in eontset with one another on at least one side of the gruit, us it is at this point of contact where the union begius to take place. In order to ensuro a sjeerly and suecessful union, waxed cotton threal is wound tightly around to hold the parts togrether. Aniateurs are also advised to rub grafting wax all over where the two parts are juinel, us with this treatment, success is likely to be more certain.

The operation having been completed, the grafts are pachen away in mosis or anwdust until spring. They ure then pliasted out in nursery rows about iliree feet apart and one ant apart in the row, the print of union being alosut three inches below the surface of the soil. "The groum shumbl then be kept thoroughly cultiviterl througliout the sinum.

Crown Grofling.-Crown grafting is usually done on young stoclis in tho nursery row in the spring. 'The trees are eut at or just benenth the surfice of the soil nt the crown or collar. A sloping" cleft is then mede in the side of the clown ant a seion, cut wolge-shape at the bower cud, is inserted in the cleft. The same precautions should he "werved as in root-grafting, of having the inner burk of both stuck and seion touehing on at least one side. The grafted part should then be well eovered with grufting wax, in order to exclule the air. The trees usually muke a strong growth when grafted in this way, but as the work has to be done in April before growth begins it is iften inconvenient $t$ ' do it at that buss season of the year.

Fop Grafting.-Plum trees are not top grafted as froquently as apple trees, but they can be very suecessfully grafted in this way. When there are trees which produes pmor or unprofitable fruit they may be made to bear good fruit by top grafting other varioties upon then. An unsymmetrical top may also bo improsea by top grafting. European ol. Japanese varieties should unt be top grafted on Americana or Nigra stock. In our experience at the Central Experimental Farm it has been found that although a good union is made the liuropean will outgrow the Americana so much that the top will die a few years after grafting, the trunk of the stock expancling too slowly. It nuay be mentioned here that it is a good practice to slit the bark of the stock in top-grafted plum trees if there is an indication of its getting hidebound. In top grufting plums it is best to have both stock and scion as nearly related botanically as possible. 'Ton' grafting is done in the spring before growth begins, and early grafting is more important witl the plum than with the apple. As the shock to a linge tree would be rery great if all the branches, on which leaves develop, were cut of the first season, about threo years sliould be deroted to changing the top of the tree. Cleft grafting is the method usually adopted in top working plum trees, it being siuple and satisfaetory.

'The branches to be grafted slonld not excred one inch and a half or two inches in diumeter. If they are larger, it is so long before the stub heals over, that disease may set in. It is possible, however, to gruft lurger branches by putting in more seions. Tho top erafting of a large tree should be done with a view to having the new top as symmetrical as possible, and great care should be taken in selecting tho branches to bo grafted upon. After the branch is sawn off it is cleft by means of a mallet and strong knife to the depth of an incls and a liulf to two inehes. It is held open to receive the scion by driving a wedge in it. Sicions for use in top graftiug are eut from dormant wioxl which has been kept in goud condition in the manner already described. They slould have alout three strong burls and be cut wedge shape at the base, one side, howprop, bcing a little thicker than the other. Two scions are now inserted in the cleft of 11. stub, with the wide side of the wedge on the outside, and thrust down until the lrwest buil is almost on a line witlt the edge of the stub. The inner bark of botll scion and stub should meet at some point, so that the union will take pluce readily, and this is more eavily effected if the scion is given a slightly outwart slope when inserted. When the widge lias ixen withdrawn from the eleft the advantage of having the wedge. ahaped end of th. 'hicker on one side will be apparent, as it will be held much 43-3 
mure tightly than if buth sides were the snme. If the seion is not a tight fit all along. there is sonetling wroug in the way it has been cut or the stul, has liren cleft. The cut parts should now be eovereyl with grafting wax to exelude the air and hold the seio.s in place. Cotton is also sometimes wrapmi around the wax in ordor to mom eflectively hold the scion in plince. If lonth of the scions grafted and the surfice of the stub at linist partially healed wer.

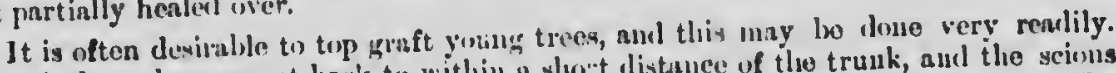
The main branches are cut back to within a slo:t distance of the trunk, and the scions

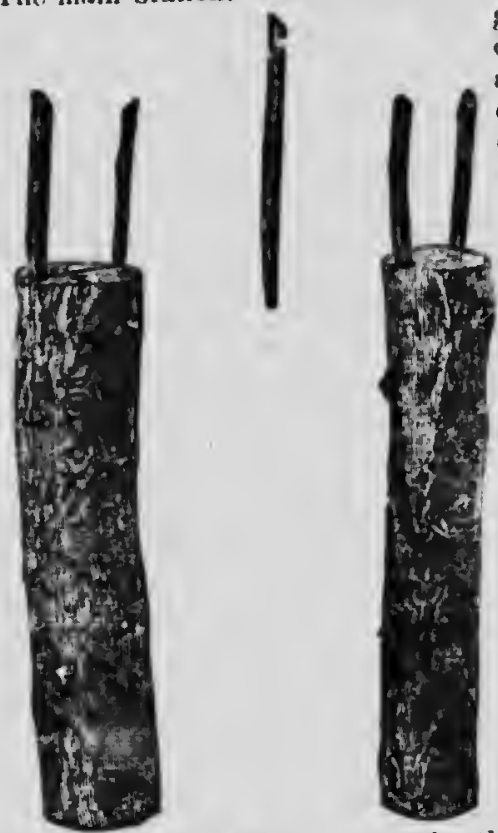
graftel on, eitlier ly eleft or whip grafting. The clower the graftel purt is to the trunk, the letter, as the tree will be strunger than if the union oreurred furthor ont on the liuls, since the grow th of graft and scion may not le equal. It is possible to cut off the whole top of the tree and grift suceessfully on the main trunk, when the tree is young, but unless one is sure that the union will le perfect and the tep not outgrow the stock, it is better not to ron the risk of iosing the tree. Furthermore, if the whole tup is cut off there will be such a growth the first season that the sciuns are liable to get broken off. In top grufting a young treo that hins been planted from three to five years, it is b:tter to takr + wo sensons to do the work, as the results will $1 \rightarrow$ a rule, more satisfnetory.

It is nee sinly to examine the gafted trees during the smi.mer and re. B any young showts from the stocks which are interfering with the scions. It is not wise, hwever, especially when the tree lins been cut bick severely for grafting, to renove all the shoots until the grafts have giown consirlewilly and furmislı a gond leaf surfaee.

While arnfting implements and appliances are numerous, the work call lie clone witl a few, and as it is not often convenient for the farmer or fru:t. grower to get a large outf:t, only the really newrssary things are mentioned. These are:- 1 slinrp, finetootherl hand saw, to be used for sawing off large lirnls, or for making the stubs on trees to bu top-grafted where the limbs are too largo to be cut with the pruming knife.

A strong pruning knife for cutting the smaller limbs; for smosthing the wounds made by the saw or jruning sliens; for trimming off torn elliges of branclies, and for muning roots of young trees when planting.

A luadding knife, with a thin steel blake, fur removing buhd, having an ivory hamble which is made thin at the eml anl is used for laising the bitk.

A grafting knife, which is userl in top-grafting trees. Ilome-mule grafting knives con le pasily made. A stromg, sharp blale is the chicf requisite.

Pruning shears, which are intermediate in their uses letween the saw and the pruning kinife. They are used for cutting off brumelies which are too large for the latter null two small to need the saw; for rough pruning aml tor cutting seions.

A welge and mallet are also necessary in ty gratting large trees.

liullia, which is one of the hest tyin: materials. It is very strong and very plinble and is particularly useful for bandaging when budding.

Cotton yarn, which is used for tieing root grafts and is one of the most satisfuetury

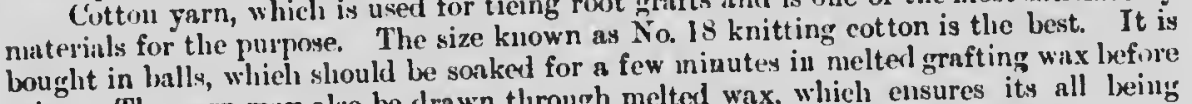
using. The yarn may also be drawn through melted wax, which ensures its all leeing thoroughly soaked, and is, perhaps, on this account preferaisle to soaking the bill. 


\section{Glistiso w.Ix.}

There are many hinds of grafting wax menumenderl, but it is unnegessitry to

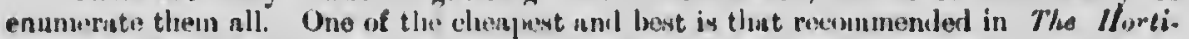

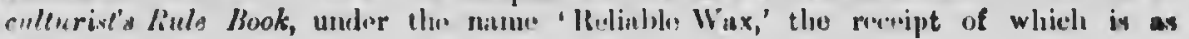
toll.,ow:s: -

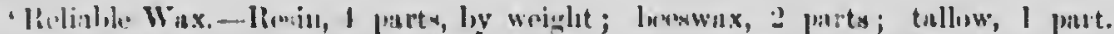

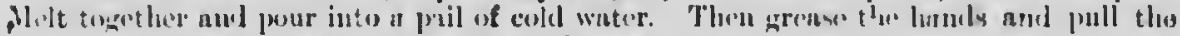

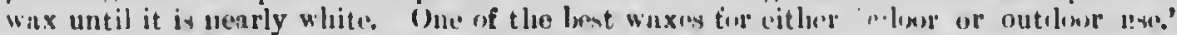

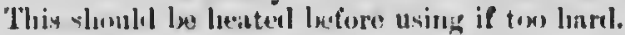

The printpal valne of grating whx is to exclule air from the wounl, and thur

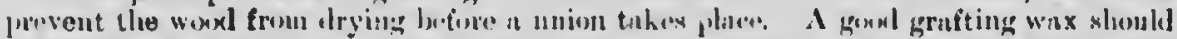
Int crack when on the tren, ehe the air will reach the ws mus and the wax prove of littlo

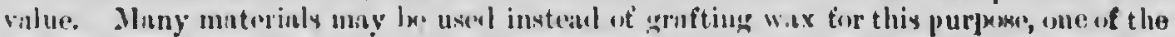
sinjplest being a mixture :

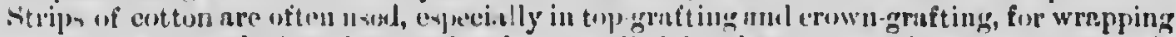

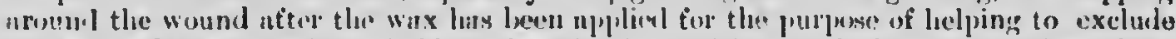
the air, and also to assist in lolllin:? the seion in position until the union takes place. This cotton is unneeessary if gexal profting wax is used ; lut if u very valuablo variety

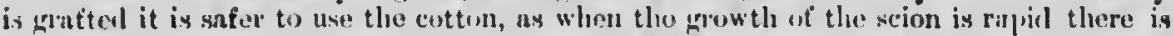

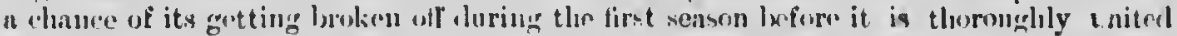
with the stock. Ialrge wounds on treen should lne covereyl with some naterial that will

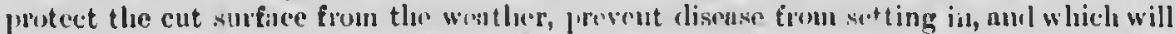

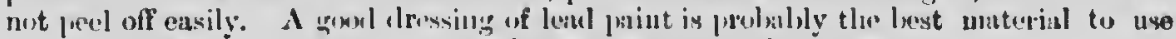

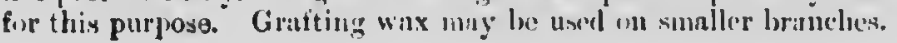

\section{TIIF NCHEEISY}

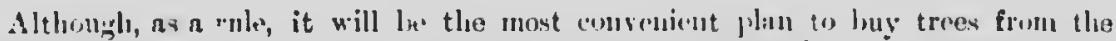

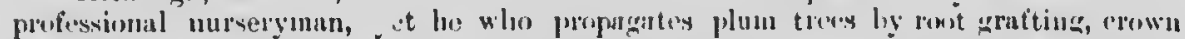

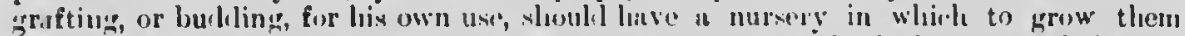
until they are resuly for the orchurl. A gonkl samily luan suil, which dines not loake anul

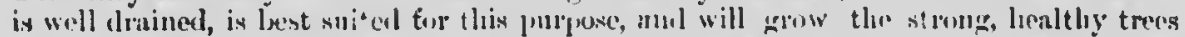

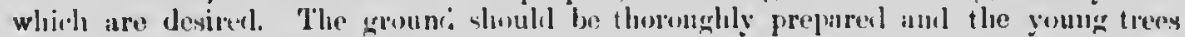

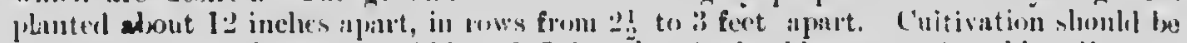

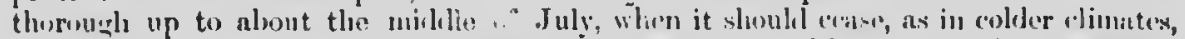

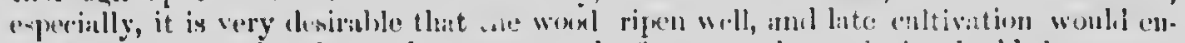

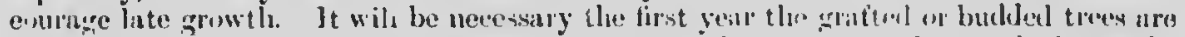

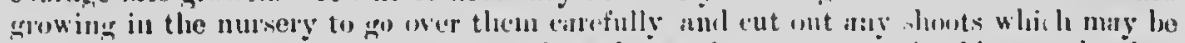
coming from the stocks, anil atso to resluer the prift to ine steni -hould more develop. If any side bronclies orom, however, they slondl te lett intact. In small nurseries it is

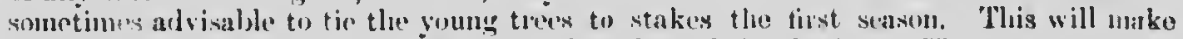

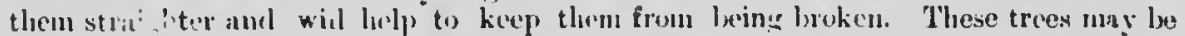

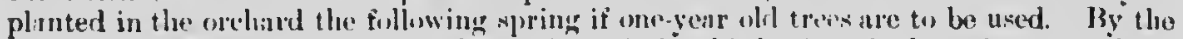

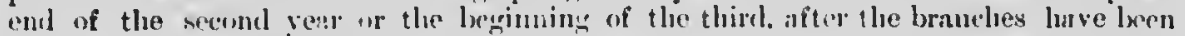

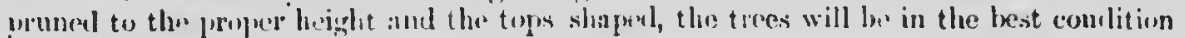
fir phanting in the onchisit.

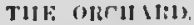

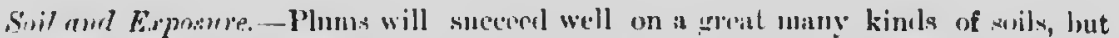

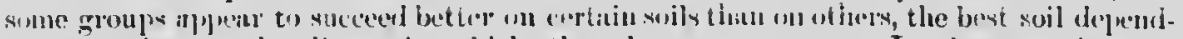
ing scomewhat on the climate in which the pluns ure grown. In those spetions of Ontario where the Furopean plums suceced best, woll draimed elay loame lias given the most sitisfactory rosults. Along the somth shore of the sit. Lawrien, inelow the city of

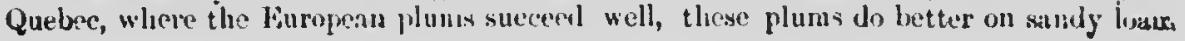


soils. The Japanese plums on th. whole give letter results on warm loamy soils than on clay lonm. The Americanas and Nigra plums succeed best on clay loam soil, but also do well on sandy loan. All soils should be well drained or suecess need not be expected. The more severe the climate in which the plums are grown the warmer the soil slioula be.

If there is danger from spring frosts a northern or north-eastern exposure would be likely to give best results, as the flower buds would not develop as soon its on a southerly exposure. The thewer buds of the European and Japanese plums suffer ladly in the north and there is no doubt that a northerly exposure would be lesst for these plunis.s.

Prepriation of the Land.-It very often hinplens that the firmer or fruit grower surldenly deeides to piant an orchard. Fo previous thought had been given to the mitter, or if there had, nothing was done to set the land into better condition for the young trees. The trees are bought, the land histily, and not very well, prepured anr! the trees set out to take their ehances. No after cultivation will fully make up for neglect of the thorough preparation of the land. Trees shonlal begin to grow thriftily from the time they are planted if they are to obtain a good size lefore they begin to bear heavily, and it the land is not thoroughly prepared and in good condition when they are planterl, grwwth is likely to le slow. It is much letter, if one lus no land in gool eondition, to delay planting a year, anul give the sonl the necessary attention. The time will not be lust, as the trees will do much better. Land which his been well manured for root erops, ploughed in the autumm, and ag:an ploughed in the spring and thoroughly levelled and pulverized with the harrow should be in gowl eondition for planting the trees. If the absoil is near the surface the sulssoil plough should be used after the ordianry one, loosening the soil from foul to six inches decper than the former.

Sud land plougherl in the autumn, top dressed in the spring with a good coating of barn-yard manure ant then ploughed aginin and thoroughly pulverized with the harrew, should also bring the soil into good conclition. A green erop, such as clover plonghed under in the spring and the land thoroughly liarrowed, wonld also be a very good methol.

Laying Out of the Orchard.-Plum trees require thorough spraying, and this shomld lee taken into consideration when plarting so thit the trees will not be set too elose. Trees should also have abundanee of sunlight to thrive best and produce fruit of goorl eolour, and they cunnot obtain this if they are too crowded. There are several goorl methods which may lxe adopted in laying out the orchard.

If the trees are planted the sane distance apart each way with a view to laving them all as permanent trees, they should be planted from 15 to 20 feet apart, depending on the varieties elosen. If, liowever, the bre nehing and upright growing rarietics were mixed as might be necensary for goxl follination, is feet apart would be a very sittiefuctury distance to plant.

Anether gond methol is to plant the trees a greitem distance apart ono way than the other. This is a satisfactory system when properly earried cout. By this plan trees

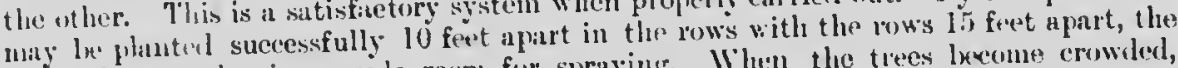
litter distanco leaving ample room for spraying. When the thees lecemes crowded, every uther une mity be taken out, thus leaving the permanent trees 20 by 15 feet alart.

I third nothoil is (o plant the trees in an apple orehard with the objucet of gotting somr profit from the lind before the apple trees conte into full bearing.

If the promanent apple temes were 35 by 35 feet apart, a row of phum trees 17 l fert anart in the row could be planted between the rows of apple trees. Plum trees

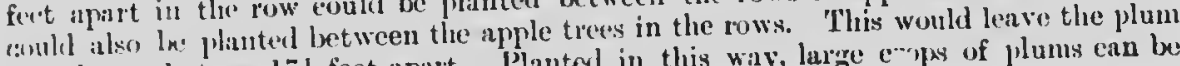

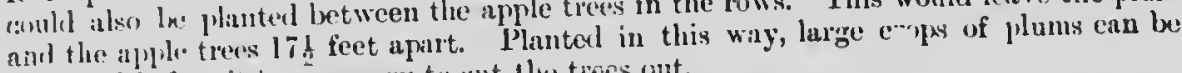
prenluced he fore it is neessary to cut the trees out.

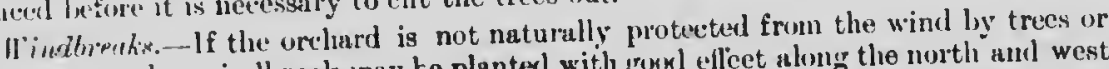
by rising grouml, a windbreak inay te planterl with goorl eflect along the north and west siles, or any other side from which the greatest injury eomes, the object locing not to stop, the winl altogether, but simply to eheek its velocity, $n . s$ if a windbreak is high and very den:a it stenss the circulation of air in the orchard to a large extent, and this gives 
very favourable eonditions for thre sprend of both inseret pests and plant disenses. On the other hand, a proper windbreak lessens the foree of the wind and thus protects the trees, which will grow straighter and shapelier; it will also very nuterially lessen the amount of windfalls, and it will permit of growing varieties which will not succeed unler ordinary exposure. Wind is one of the most important fietors in chying out the land and cansing dronght. If its foree is elecked by a windbreak the evilporition of inoisture fiom the soil will not be so great.

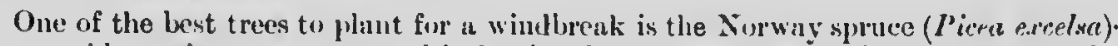
It is a rapid growing evergreen and is harly ahnost everywhere where plums ean bo grown suceessfully. $\Lambda$ single row of these trees plantrul fiom 8 to 10 fret apart is quite

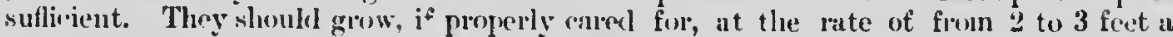
year until they reach a hright of sol to bin feet. In very expeserl places it may he ilesiralle to plant two rows of trees, the trees forming the second row being plinted

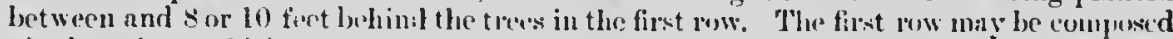

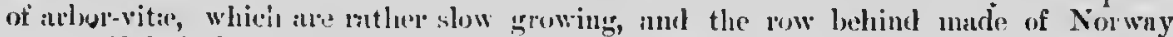
spruce, if dexirnble. White pine and European buch are rapid growing trees which

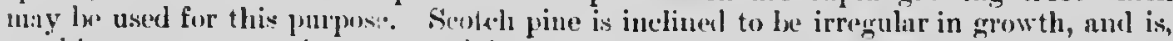

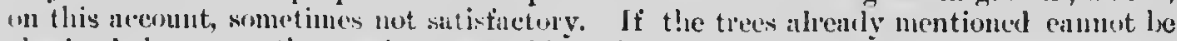
oltaninel there are other native trees which will give grook satisfiction.

Kind of Traps lo Ilont. - Plum trees one or two vears of are will give the hest siltivtiction. If the planter dees all the enltivation himself, suall trees will be more witinfietury, as they start more rendily than larger ones, but if hired help is employed il groul sizid tree in important, as smill sized trees alre lialle to be trampel down or other wise injurel. The paragriph on stopks should be read carefully, as the stock of the plum pliags all ingurtant part in the growth of the tree.

Plenting. - The suring i the best tine to plant plum trees, and the earlier it is wher the leetter, providing the soil is dey anongh to work without pullling. Plum trees sullio muce from late plunting than alple trees. The trees may he planted with suceess in the alutumn if the work is rone parle, as they will throw out roots before winter, but it planterl late they are very likely to be killed by drying ont. As it is of the greatest inportance to get the trees planted early in the spring and as when orlererl from nureryme'n in the spring, it is diflieult to get them as early as requirerl, a gexel plan is to orker them to be doliveres in autumn and when reeeived hrel them in well drined soil until spring. After the trees are taken out of the soil great care should be taken to prevent the roots from becouning dry before ylanting, as if they do the tree is amost sure to rlie. Dipping the roots in a thin mixture of elay loun anul wilter will protect them somewhat, but wet burlap, old bains, or wret straw should aleo te userl. Beforre exposing the roots of the troes, lioweser, the holes should be mide. Whuy planters snem to have the illea that if they dig a hole

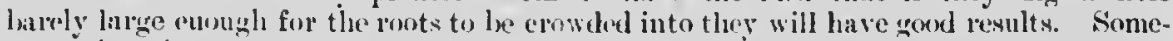
times they do; nueh oftence they du not. If the whole field has been subusiled and is in a thorough state of tillage it wealh not matter so mueh, as the snil all over would be in the sane state of friability, but this is rere ravely the case. So that, as a rule, it is necessary to make the hole somewhit litupe than will accommolate the roots, spreacl out to theril full extent. It shon hll be mirke al out 18 inches deep, after which the sub. soil should be loosench a firw inches more, but not removed. In digging the holie, the

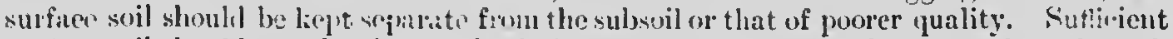
mutine soil should now be thrown lack in the hole to make the tre, when pianted,

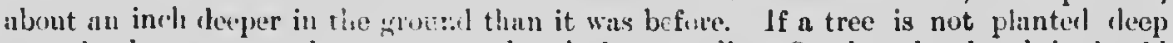

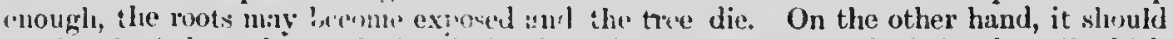

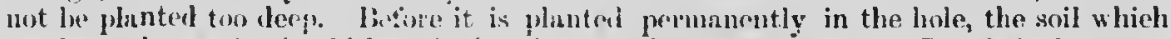
has been thrown in shouid be rivied and rounded ofl in the eentre. If this is done, the rints of the tres pun be spreal wat much move realily and plaeed more in their natural fosition. R.uts of plum trees lave not many fibres and it is necessary to spread what are left 'nl the trre, carefully, in onder to get the best results. Broken or bruised ruots ahould be cut off before planting the tree. 
The tree being now placed upright in the hole and the roots earefully spread out, thes surfice soil is gently thrown in ind worket in among them, by the hand, if necessary. It is very inportant to have the seil come in close contate with the root fibses, in order that the best conditions may be afford ed the tree to beyin arow th promptly. W' hen the? rents are well eovered, tnore gow soil slundel be thrown in and when the lisle is about hasf full it shonld be well tramperl with the feet, after which the hole should be filled lovel with the surface of the soil, tramping loing done while it is leing tilled. The surfiane of the soil should lee loft loose, as this will help to prevent evaporation of muinture thom th. weil which has bern thrown in, It is not neressary to water ang tree if plant-

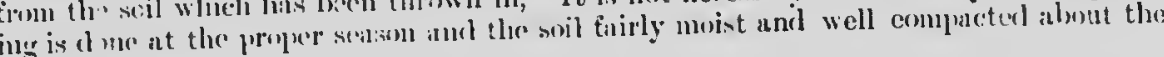
roots.

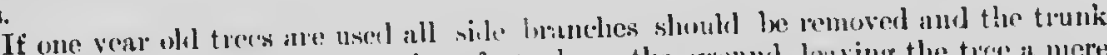

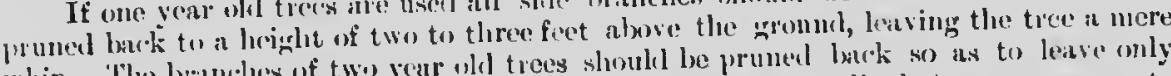

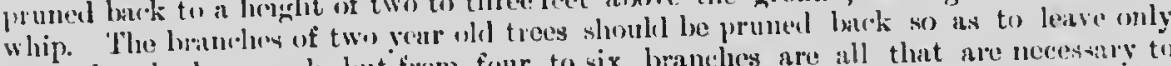
about fonr luds on mich, lut fiom four to six branches are all that are necestary to mike a goon and svometrical top and others should be cut back to the trunt. "The

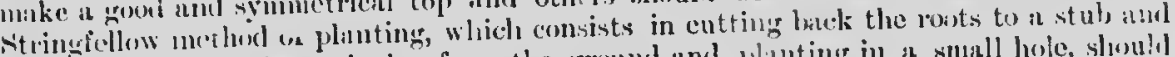
the top to aimat rightern inclies from the ground and plinting in a small hole, slowill $h_{1}$. Inaciserd with caution in the provinces of Ontario and Qnelece.

If the orelain is in all exposed position and tho trees large and with high trunks, it will pay to ti stakes to them to keep them from grotting loose.

In districts whore drought is liable to ocenr, or even in places where the sist?

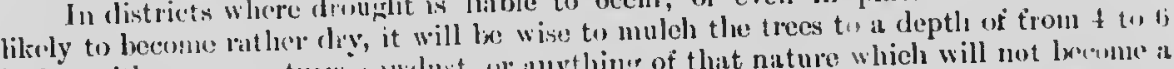
inches with m:unre, straw; whilut, w anything of that nature which will not lwome it compact miss. If this is plice alout the hase of the tree and left during the summer it will keep the surfice soil loose and prevent caiporation of morsture and the growth of the trees will be much more rapid. A goorl mulch may be the means of preventing is tree from dlying it the sestson is very unfavourable or the tree in poor condition. If the muleh is loose when winter sets in there may le dinger from mice, and this slinuld lo guatulet anginst.

\section{Varieties.}

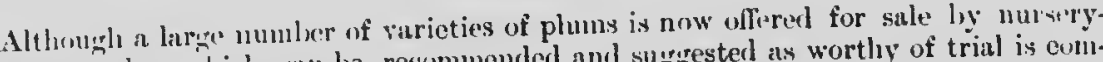
mon, the mumlere which "un be recommended and sugrgested ats wortly of trial is eomparatively limited. Few additions larve been made of late years to the list of best Eumpen plums, the greitest number of new namel varieties having eome either from the Jajimese ne nitive plums, A considerable number of hybrid varieties have bren introluced yuite recently, but most of these have not yet been sntfieiently testorl to jurlge of their merits. Great improvement has been male in the Americana and other North . Imerican pluns, and a great many mamed varieties have been introrlueci, no less t than $1: 37$ of which are being tested at the Contral Experimental Farm.

'The plum season extrinls over a period of about three months, beginning alout the

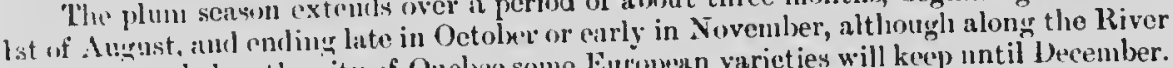
Sit. Iaw whe beluw the city of Quchee some Euroun varieties will keep until becember.

liv a judlicious selection, varieties may be planted which will give an unt oken surcesion ut lip. truit during this perionl. The market to which the plums are to he sent $x$ ! vitrieticu will be the most satisfectory.

In Bulletien No. 37, on Apple Culture, published by the writer, the provinees of Ont:uin and Quphece were livided into thirteen dillerent distriets, represonting in a

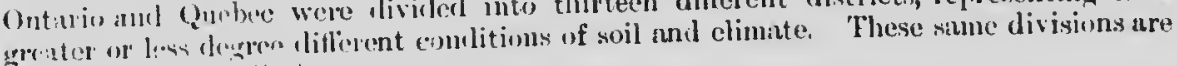
adoptial in this Bulletiu.

Although the variaties recommenderl are likely to be the most suitable, the intendinf planter should lean what varieties are proving the most prolitalle in his vicinity. This is important, as the districts are largo and wonditions will vary somewhat from one end of a distriet to the other. 'The lines dividing the distriets are not arbitray. It is not pussible to malk. :ul exach liviling line on one side of which a variety will du well 
aud on the other side of which it will prove a failure. The boundary lines are surgentive only. It is often the case that there will be esprecially unfavonrable locations for ojelards in a milder district in which it would be safer to plant the varieties reconmenulerl for a colder one. The planter should use his jumligment in the mutter.

In Bulletin No. 3i, an Apple Culture, a map was publisher showing thi ditfindut districts in the provinees of Ontario and Quelnec. Unfortun at ly this mip wis destrogerl

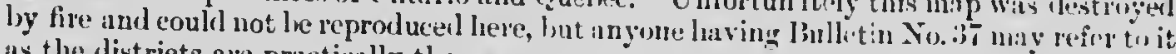
as the distriets are practically the same.

The varieties recommended in the following list are arranged, as far as possible, in order of ripening, beginning with the curliest. It was only througl the kincinews of in lange number of Canalian fruit grower's that it las been possible to prepare a list of the lest varieties for the different distriets. These men have given the resulty of tlirive experiences most willingly, and I take this opportunity of a gain thanking then publicly for
tlreir assistance.

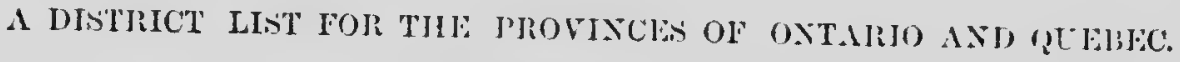

\section{DIsTlicts J ANI) 2.}

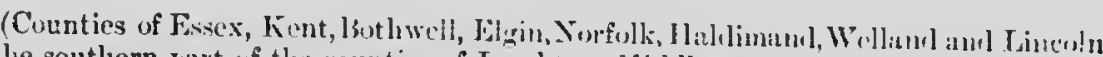

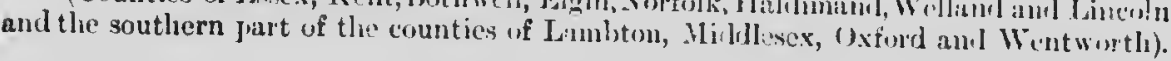

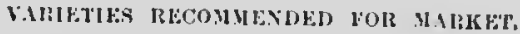

Eirropan.-Bradshaw, Inperial Gase, Lombard, Jalay, Itulian I'une, Shropslire Damson, Grand Duke, IIonarcli.

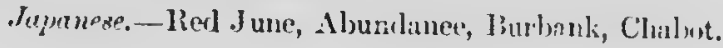

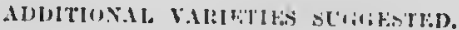

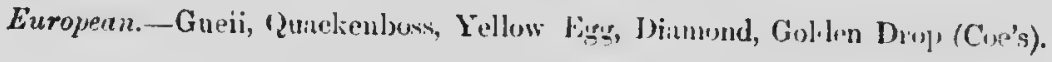

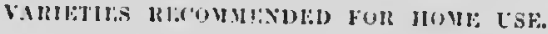

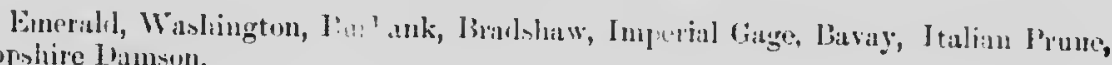
Shrophire bumson.

\section{DISTIIT"T 3.}

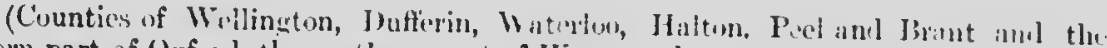
eastern part of Oxforl, the urentliern pirt of Wentworth, the western part of fork and the sisuthern part of simese).

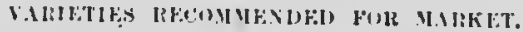
Baway.

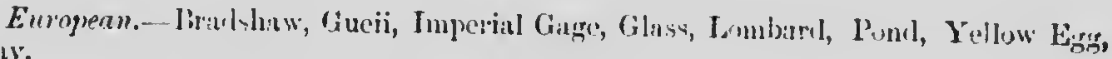

Tupuness.-Diel June, Abundanee, Isurbank.

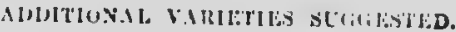

Mount Royal, Riı̧ıes, Stanton, Clabot. 
VARIETIES RECOMMENDED TOR HOME USE.

Washington, Burbank, Bradshaw, Imperial Gage, Lombard, Bavaj.

\section{DISTRICT 4.}

(The northern parts of Lambton, Middlesex and Oxford; the counties of Perth, Iluron, Bruce and Grey and the county of Simcoe with the exception of the extreme suuther'n portion).

VARIETIES RI:CONYVEIIII FOR MALILET.

Europeun.-Bradslaw, Imperial Gıge, Glass, Lombara, Yellow Egg, Bavay, Italiın Prune, Monarel..

Japanese.-1hed June, Aluundanee, Burbank, Cliabot.

ADUITIONAL VARIETIES SUGGESTED.

Grand Dulse, Dianond.

VALIETLES RECONMENDED FOR HOME USE.

Washington, Burlank, Bradsliaw, Imperial Gage, Bivay, lains.an Pruno.

\section{DISTRICT 5.}

(The eounty of York with the exception of the extreme western portion and the counties of Ontario, Durhain, Northumberland, Prinee lidward, Lenuox, Frontenate to Kingston, and IIastings and Addington, within thirty miles of the St. Lawrence liver; also the southern portion of Vieturia and Peterborough 1 ).

VARIHTIKS RLCOMMLSDHD FOR MAHKLT.

European.--Bradshaw, Gueii, Imperial Gage, Glase, Lombard, Yelle Fę̆, Bas ay Italian Prune.

Jipmese.-lied Juae, Abundanee, Bulbank.

ADDITIONAL, VAHIFTES SCritixtrid.

Grand Duke, Diamund, Monareh, Chabot.

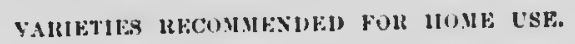

Wavlington, MeTaughlin, Burbauk, Bradslaw, Imperial Gige, Bavay, Italian Prune, Shropishire Dainson.

\section{I)ITIRT 6.}

(County of IReds, Grenvile, lyutdin, Sturmont).

VAILIFILS RECONMRYIIIN FOR MARKET.

Americana and Nigra.-Aitkin, Bixby, Mankato, Clieney, Wolf, U.S., Hawkeye, Stoddard. 


\section{AUDITIONAL VARIFTIES SUGGRTED.}

Anericana -Terry, Smith, Atkins, Bouncer.

Wildgoose.-Whitaker, Milton.

\section{VARIETIES RECOMMENDED FOR HOMY USE.} Jawkege.

Americana, Nigra and Wildyonse,--Bixly, Matkoco, Cheney, Whitaker, Cuttrell,
kıje. EUR'PHAX SUGGLSTFD FOR TILISL

Early Red Russian, Lunn, Mount Roynil, liayney, Richland, Gueii, Glass, Arctic, Lombard, Whito Nicholas, Yellow Eigr.

None of the European pluins are very satisfactory in this district, as the fruit buds of most varieties are usually killed by winter.

\section{JAPANKSE SLGGESTEL FOK THAL}

Red June, Burbank.

\section{DISTRICT 7.}

(The counties of Victoria, Peterborough, Hastings and Allington, exreept thos southern portions; Manitoulin and St. Joseph Islands, and the counties of Renficw, Ianark, Carleton, Russell, Prescott, Glengarry ; the counties of Pontiac, Wriglit, and Ottawa south of latitude 46 ; also the eounties of Argenteuil, Two Mountains, Terrebunne, L'Assomption; and Montcaln, Joliette, Besthier: Maskinonge, and St. Maurice, within 25 miles of the St. Jawrence River.)

\section{VARHETES RECONMEXDVE FOR MAIEKET.}

Americana and Nigra.-Eariest and best na ive secdlings, Aitkin, Bixby, Mankato, Clienep, Wolf, U.S., Hawkeye, Studdard.

ADDITION.I VAII:THES SCGiI:STED.

Americuna.-Terry, si h, Atkins, Bender, Queen, Kineth, Eta, Bounrer. Ihese are newer varict in, highly recommended by exronimenters.

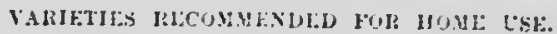

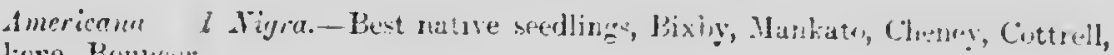
Hawlieve, Bouncer:

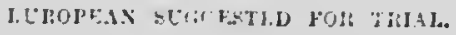

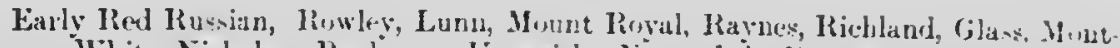

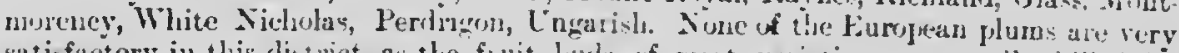

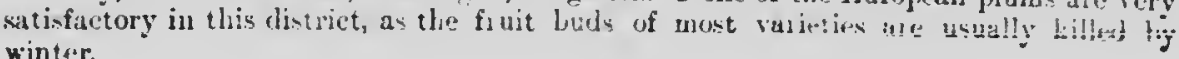
winter.

lied June, Burbank. 


\section{DISTRICT 8.}

(Counties of Muntingdon, Brauharnois, Chateaugnay, Jaeques Cartior, Iaval, Heche'ag, Chambly, Iaprairic, Nepierville, St. Jolins, and the western part of Ileerville and Missisquoi).

\section{VARILTLS HKCOMMLYNDLD FCR MARKKT.}

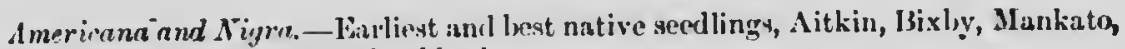
Cheney, Wilf, U.S., Hawkeye, Stuxldiard.

European.-Mount Iioyal, liagnes, Mtstmorency.

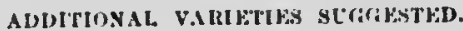

Americana.-Terry, Sinitl, Atkins,

Europmen.-Aretic, Glass, Yellow Egg, Richland, Farly Red Rnsian, White Nicholas, Iombarl, Damsutr.

\section{VARIFTIEA HECOM MEXDED FOR HOME T'SE.}

Americana and Migra.--Mixby, Mankato, Cheney, Cottrell, Hawkeye.

European.-Lunn, Raynes, Muunt Royal, Brodie, MeLaughlin, Montmorency, Green Gage, Queen May, Perdrigon, Ungarish.

\section{JAPAXYSL: SLGiRTSTED FOR TRIAL.}

Red June, Burbank.

\section{DISTRRIC'T 9.}

(Countin of Verchies, Richelieu, Yamaska, St. Hyaeinthe, Rouville, Bagot, Orumnoml, Richmond, Shefford, Sherbrooke, Brome, Stansteud, and the eastern part of lberville and Missisquoi and the western part of Compton).

\section{VALTFTIES RECONMLYNDD FOR MARKFT.}

Americana and Nigra.-Best early native seedlings, Bixby, Mankato, C'luney, Wolf, U.S., Hawkege, Stixdlard.

\section{ADUTTOY.AL VALLTILS SLGGESTED.}

Ampricena aml Vigra.-Terry, Smitl, Atkins, Bender, Queen, Kieth, Iitta, Bouncer.

Europern.-.Inount Royal, Raynes, Glass, Riehland, larly lied Russian, White Nicholas.

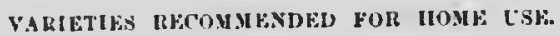

Amprirana and Higra.-Bixl,y, Mankito, Cheney, Cottrell, IIawkeye.

MLROPEAN SU(iGESTHE.

Lunn, Mount Royal, Broxlie, Montmorency, Glass, Richland, Early Red Russian, White Nicholas, Aretic, Damson, Ungarisl. 
JAFANESE 8UGGKATED YOA TRML.

lind June, Burlank.

DISTRICT 10.

(Counties of Nicolet, Arthabaska, Wolfe, the eastern part of Compton and the counties of Beauce, Megantic, Dorchesfer, Intbiniere, Iavis and Bellechusses).

VARIETH:Y IRCoMMEXIHF. Americana and Nigra.-Best carly mative seellings, Aitkin, Jixlby, Mankato
Chency, Wolf, U.S., Hawkeye, Storlharl.

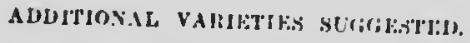

Americana.-Terry, Smith, Atkins, Beuder, Qucen, Kicth, Litta, Bunncer.

VARIFTES RHCOMMENDED Fon HOMH: CSF.

Americana and Migra.-Bixloy, Mankat", Cleney, Cottrell, Hawki.yo.

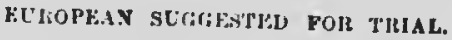

Iunn, Mount Poyal, Raynes, Beritie, Qmern May, Farly Red Russian, Whito Nicholas, Aretic, Ungarisl.

JAPANESU SUGGFFTHE FGI TILAL.

Red June, Burbank.

\section{i)ITKICT 11.}

(Counties of Montmagny, I'Isket, Kamouraska, must of 'Temiscruata, Bunaventure, and Gaspi on the Bay of Clakeur side to (iaspic hasin).

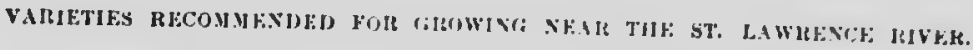

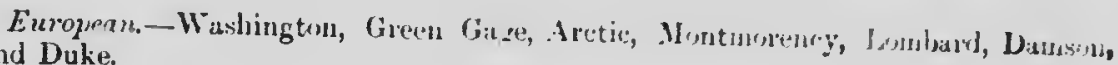
Grand Duke.

\section{ADDITIONAL VARIFIRS SL GOBSTHED.}

Mount Royal, Iritynes.

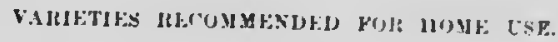

Washington, Inperial Gage, Green Gage, Aretie, Josubard, Jamson.

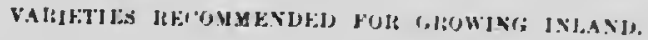

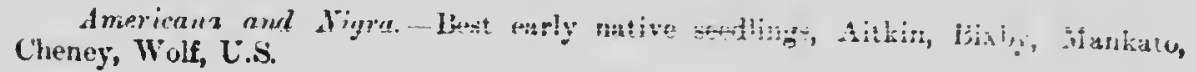

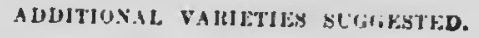

Americana. - Terry, Swith, Bender, kitl. 
VARIETIES RECOYHENDED YoR HOME USE.

Bixby, Mankato, Cheney, Cottrell.

\section{DISTRICT 12.}

(Counties of Chunplain, Portneuf, Quebee, Montmorency, Charlewix, and Chieratimi, east of the St. Maurico River and south-west of Iake St. Jol.n and to the St. Iawrence River.)

\section{VAHETIKS IREOMMENDFD.}

Best eatly nativo secdlings, Aitkin, Cheney, Bixby, Wolf, Cottrell, U.S.

\section{ADUITIONAE, VARIETIFS SI:GiGSTED.}

Terry, Smith, Bunder, Etta.

Near the St. Iatwrence River, espeeially in the vieinity of Quebec and below and on the Island of Orleans, the following Furopean varieties would give inore or less sat is. faction:-Washington, Green Gage, Aretie, Montmorency, Mount Royal, Rayues, Fomlarird, Danison.

\section{DISTRICT 13.}

(North of latitule $46^{\circ}$ in Ontario, and in Quebec north of districts 7 and 12 as far as plums will grow; also the north-eastern part of Teniseouata, Rimouski, and Matane.)

VARIFTIES SUGGESTED.

Best early native scedlings, Aitkin, Odegard, Bixby, Mankato, Cheney.

\section{DESCIRIPTIONS OF VARIETIES.}

The following deseriptions were, inost of them, made by the author from sprecimens either grown nt the Central Experimental Farm or in otlier parts of the provucess of (Intario and Quebec. In some eases, however, especially among the Europran pluns, the descriptions were obtained from other sources which are eonsidered reliallde. Where these descriptions are used the author's name is given. The varieties which are descritient are diviled into the various groups to which they belong. 'llhey are limited to thuse mentined in the district lists witl the exception of a fow now linds enmsilored promising but which huse not been testerl long enough to recommeni, and a tew of the whlce valieties.

A HEICISA valriths.

\section{(Where not otheruive nutel.)}

Amarion Firgle. Fruit above melium size, roundish; euvity narrow, mediun deptli; sut ure a faibly clistinct line; apex rounded; colour deep purplish red: det \& numerwns, small, velluw; blow moderate, frale blue; skin thick and tungh; flesh deep yollow, juicy; stone mediun size, oval, slightly 1lattened, cling; sweet, rich flatsur ; quality good. Season mid.Septenber. Would be more promising if coluur were brighter. 


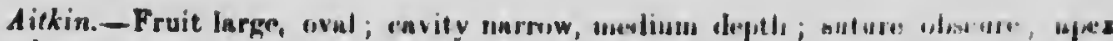

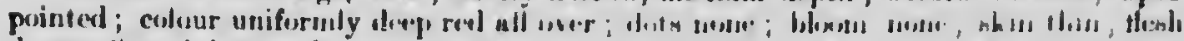

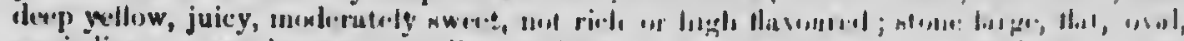

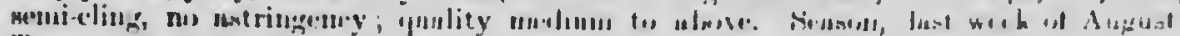

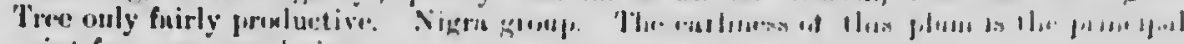
point for recoumus:alation.

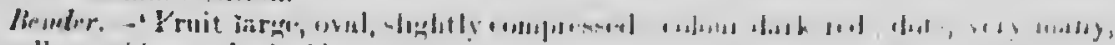

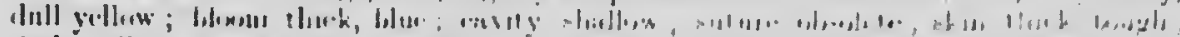

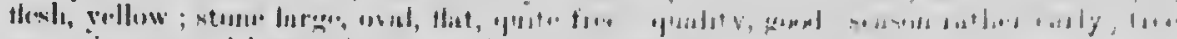

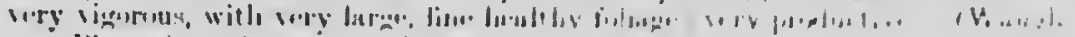

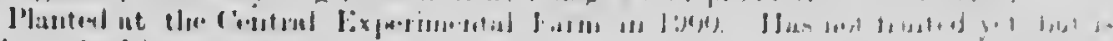

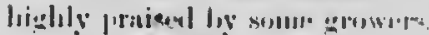

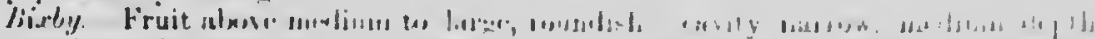

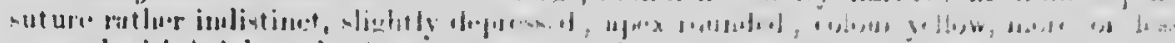

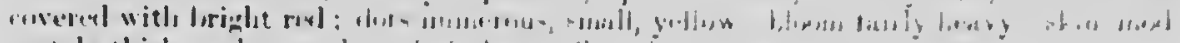

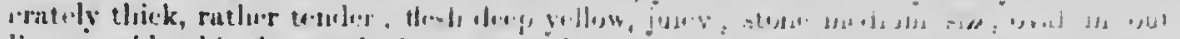

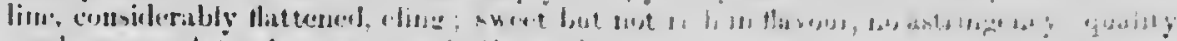

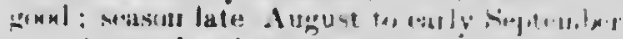

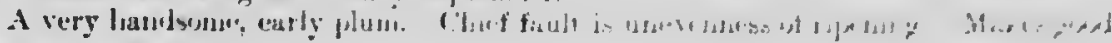
fiderervers.

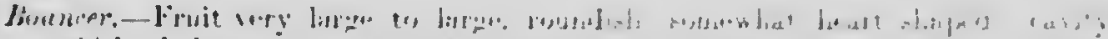

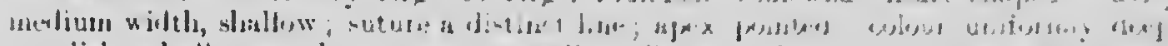

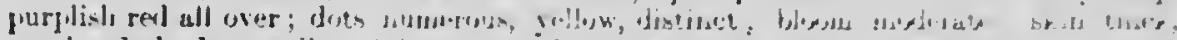

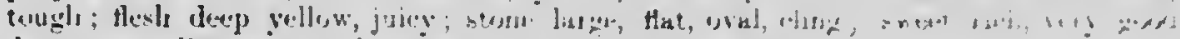

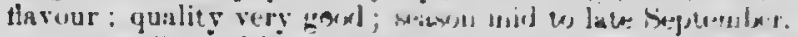

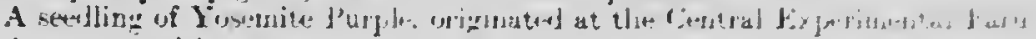

A very proniturno variaty.

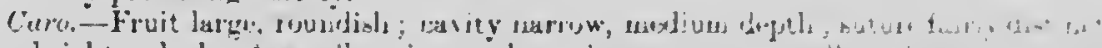

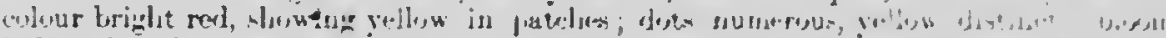

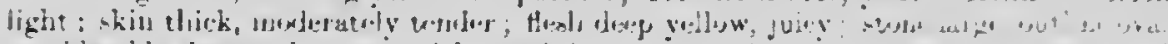

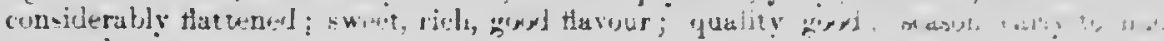

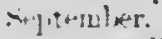

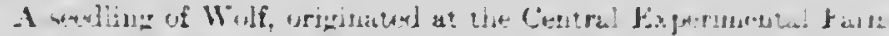

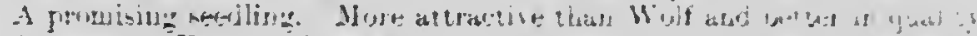

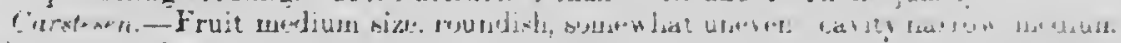

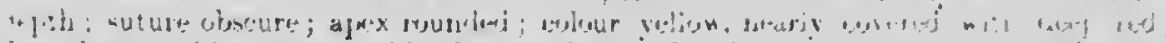

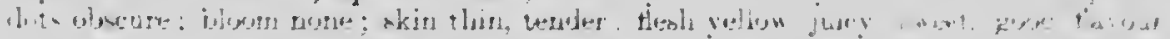

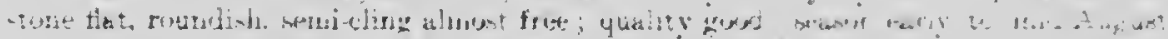

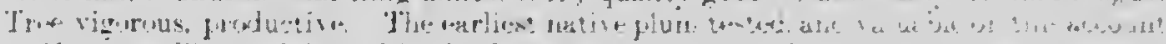

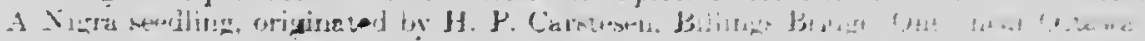

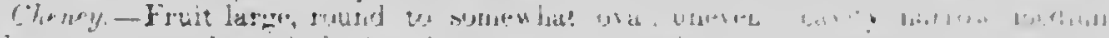

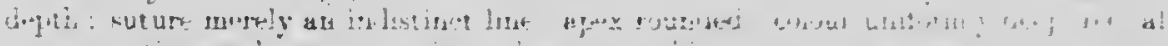

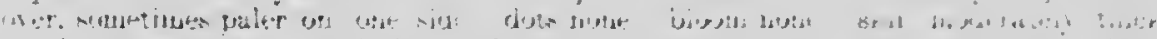

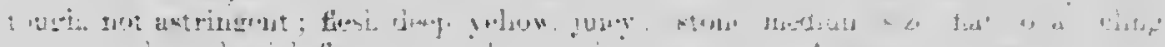

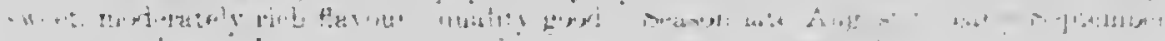

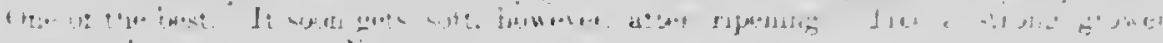

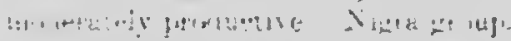

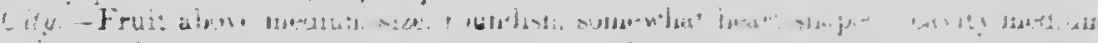

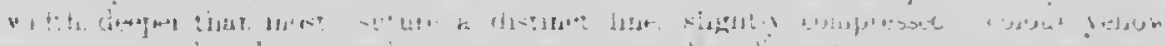

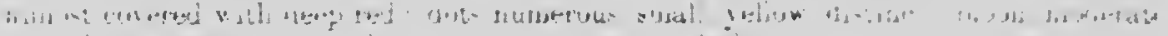

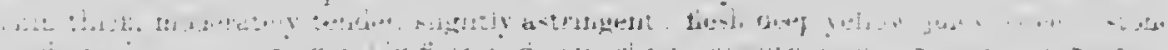

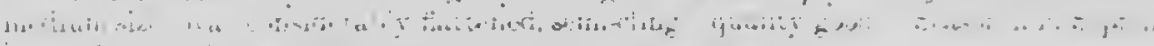

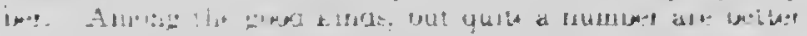

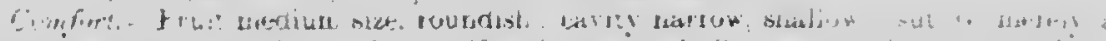

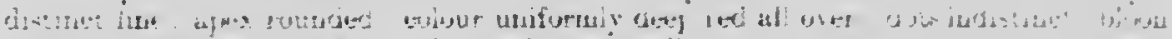

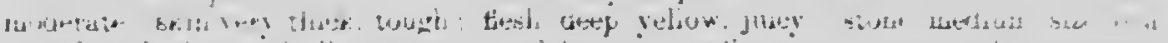

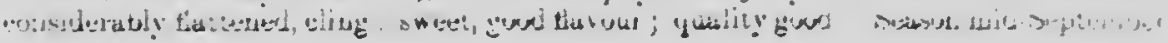




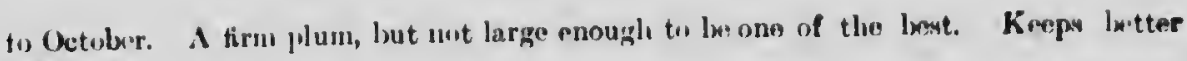
than most.

Consul. - Form large, roundish; chvity uarrow, muglium lroptls; suture a diatinct li.se; apex roumlal; colour derpl red; dots moleratuly unmeroun, yellow, distinet; loloun light ; skin rather thick, tough ; tlesh deep yellow, juicy, swert; stuno mesliun wize, ovil, consialerably flattrnml, almest free; quality gocml. Sensun late Septemler to enrly (M.tolere. $\Lambda$ smulling of Wolf uriginated at the Central lixpurimontal Furu. Will probulily prove a useful late plum.

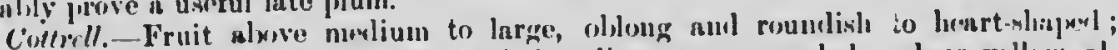
cavity nurrow, melium depth; suture a distinet line; aprex romuled; eolonr yellow, n!

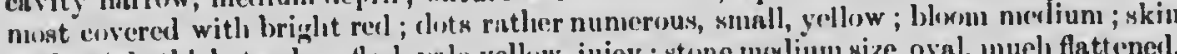
morlerituly thick, tender; flesh pale yellow, jniey ; stone mealium size, oval, muel, flattenerl, eling; sweet, gox? thwour ; quality goxul. Seasson enrly to millseptenlwer. P'romising, miakes a cood preserving plun and is attractive-looking.

Dr. Soto.--Fruit madium to alove inelium in size, roundish, sonewhat lieart-shaperl, sliglitly flat tened ; eavity narrow, neelium depth ; suture a rlistinet line; eslour d ep yel. low, well waslierl with deep reel or dark red; ilots olscure; bloom alight ; skin moxlerately thick, fairly tencler; tlenle deep yellow, juicy; stone melium size, oval, eonsillerubly flat teuryl, cling; swect, goral tlavour; quality goinl. Scason mid to lato Septemler. $\boldsymbol{\Lambda}$ groorl pluin on acermut of its yuality and great proluctiveness, but is not as large as it slioulil lee to be one of the lest.

Don.- Fruit larar, roundish ; envity narrow, melium dopth ; suture a distinet line; colour uniformly deep, lively reel all werr ; dots numerous, mall, distinet ; blonn, Inorlerite: skin thick, tough ; flosh drep yellww, juicy, firm; stone melium size, oval, somewhat flattenel, eling; sweet, rich, groirl tlavour; fuality very gool. Sensun late

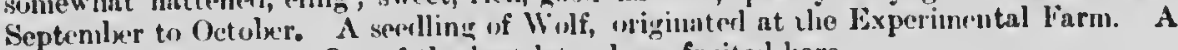
very promixing plum. One of the lest late plunis fruited here.

Dr. Dennis.-Fruit above melium to lurge, somewhint heart-slaped, flattoned; cavity narow, medium deptlı; suture a distinct line; apex rounded; colour dlecj red; dots small, numerous, distin.t ; blowm molerate; skin thick, wutlier tough ; tlesh deep yellow, juicy; stone large, flat, broal, eling; molerately sweet, slightly astringent; quality aluve medium. Sedsin mirl to late septenser. A goral variety lout not as pronisinger ats some.

Elli. - 'Fruit large, nearly rund, yellow, stripenl and splusned rith pale red ; suture distinct; skin merlium, tender; flesh sweet and rich; stonw oval, smootl, groned on back; ripe August $29,1900$. Originatel by H. A. T:r y, C'reseent, Ia ; parentage un. known, fruiting first in 1895 ; tree leseriled as a slow grower. $\boldsymbol{A}$ fine plum, at tractive in appearance, ligh in quality, anil promises to be very produetive. Worthy of trial for market.' (Goff.)

Forst Garden.-Fruit medium size, ronndislı; envity narrow, medium depth; suture a divtinet line; apex rounded; eolour yellow, alnost entirely covered with diark purplislı rial; dots smull, nuinerous, yellow; hloom moderate; skin thick, tough ; Hesh deep v(llow, juicy, swrect; stone mediun size to small, oval, eonsiderably flattenerl, cling; yuality guxd. Scason early to mirl septemler. Plum not attraetive enough to be promisin:

Groylord. - Fruit above medium to large, roundish, somewhat heart-shaped; eavity narrow, shallow ; suture a distinet line, very slightly depressed; apex pointed; eolour deep, rull red on yellow ground; dots olsscure; bloom moderate; skin thiek, rathe tough, slightly astringent ; tlesh deep yellow, juiey ; stone merlium size, oval, considlerally flattened, seni-cling; sweet, good flavour; quality goud. Season mid september. Would bos promixing if colour wore more at tractive.

Ilammer. - Fruit larere, roundish to oval ; avity narrow, medium deptlr ; sut ure is line, rat her inlistinct ; colour uniformly deep red all over ; dots inunerous, yellow, distinct. prominent : Hom laravy ; skin thick anci tough ; flesh deep yellow, juicy, meaty, sweet ; stone $\mathrm{l}_{\mathrm{c}} \mathrm{low}$ mediun size, oval, cunsiderably tlattened, eling; quality gornl. Season lato Septemler. A very hamdsome pium laving more the flavour of Miner thall Amerieana. This variety eracks bally on the trees, otleerwise it would be one of the m:st promising. 


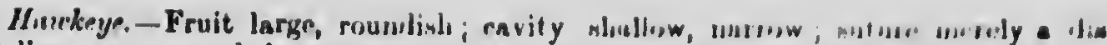

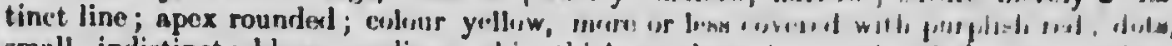

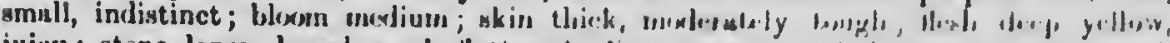

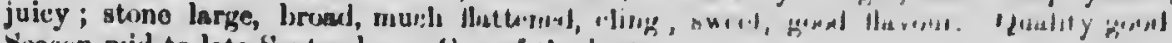

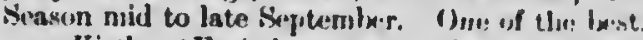

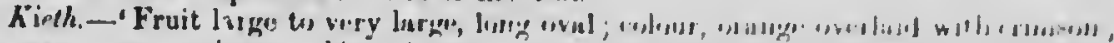

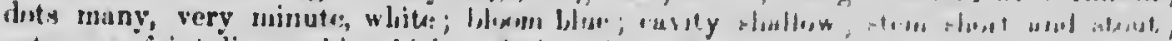

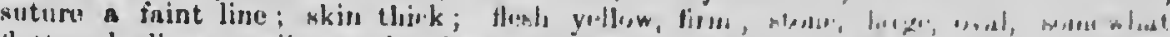

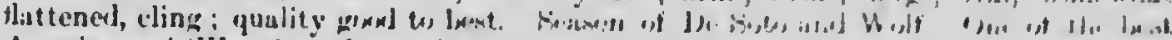

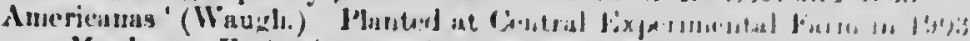

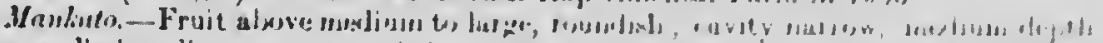

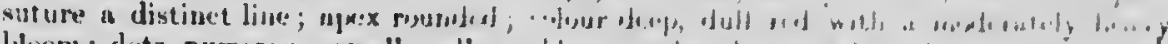

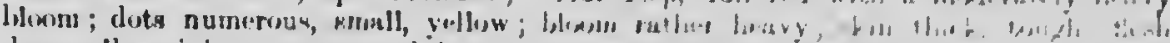

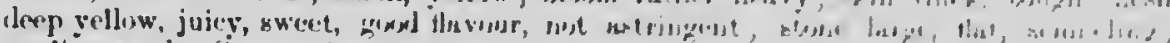

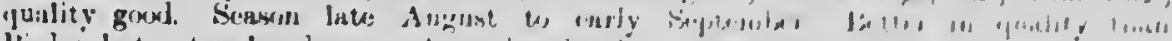

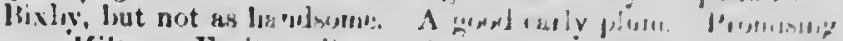

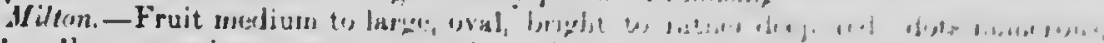

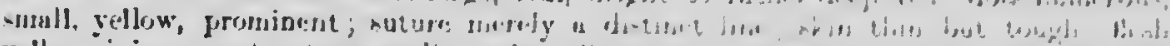

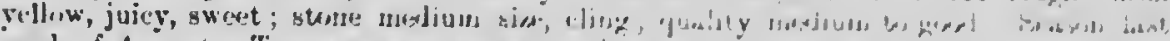

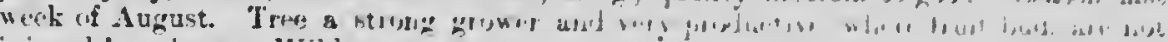

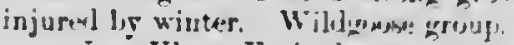

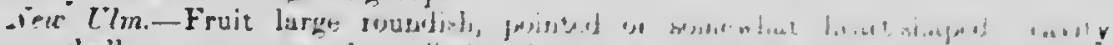

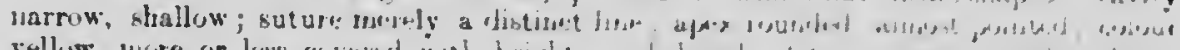

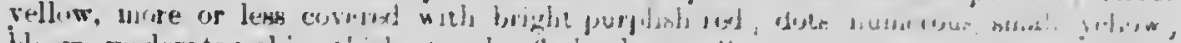

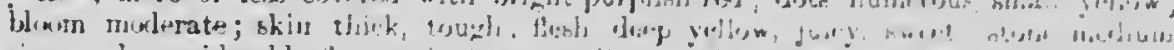

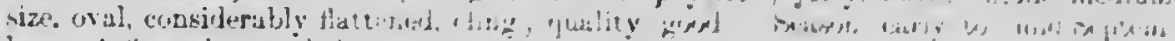

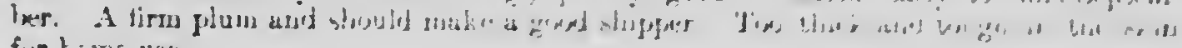
firs hiome use.

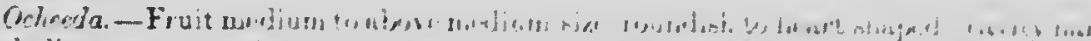

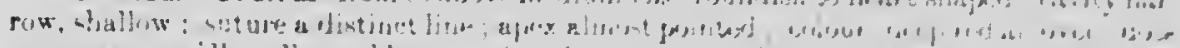

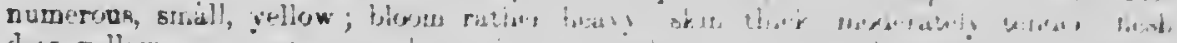

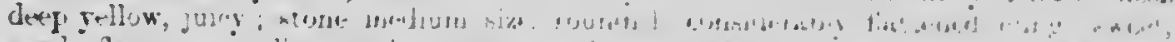

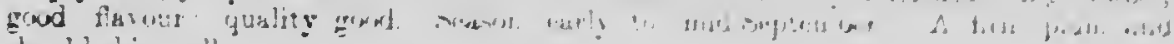
suruld thif w+il.

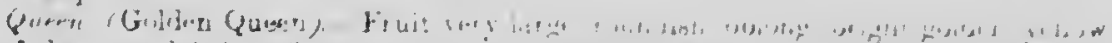

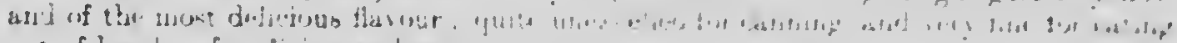

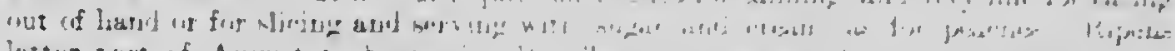

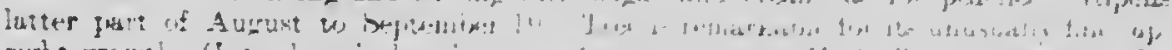

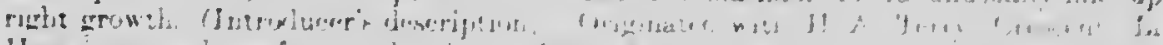

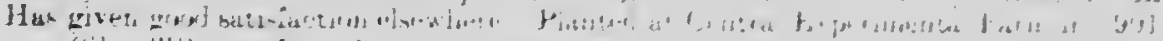

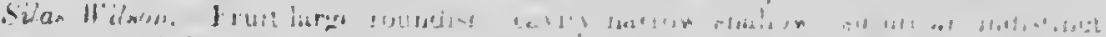

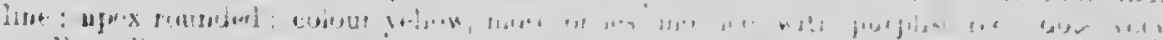

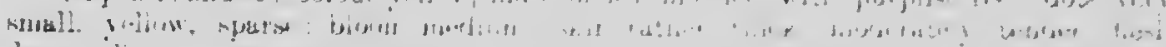

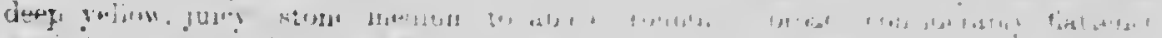

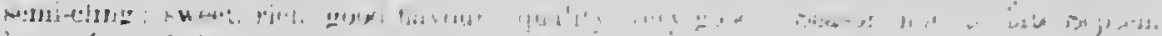

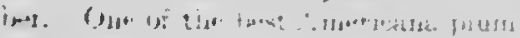

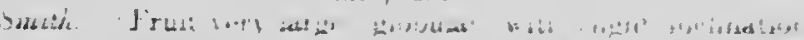

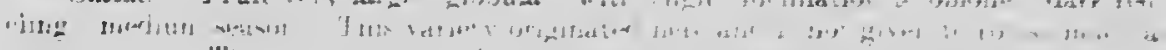

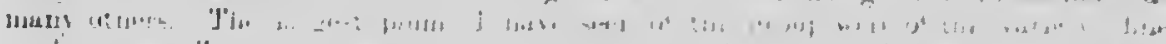

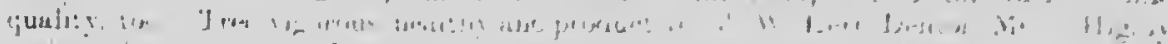

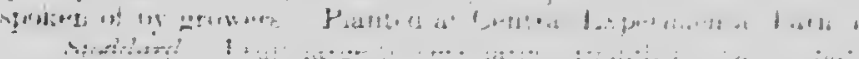

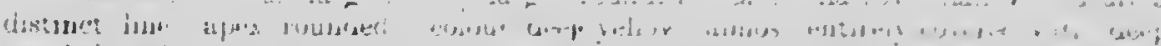

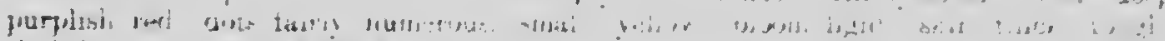

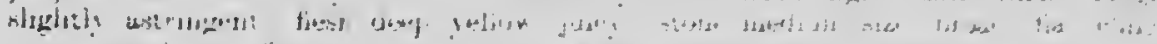
Bн

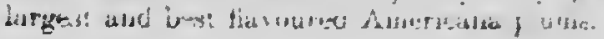


Sunrime- - Fruit large, oval ; cavity narrow, shallow; suture o distinct line, not deprenmel; a arex numblerl; eolour yellow, more or less covernd with briglit rexl; dots few, yellow, distinet; bloxn merlium, nkin thick, moderntely tough; flewh dexp yellow, juicy, swere ; ntune large, flat, oval; practienlly freo; quality goxl. Benson miclSeptember. A merlling of De Soto, originuterl at Centrml Fixperiuental Farn. J'romising oxing to freveness of stone.

Zerry(Frow Silver). - Fruit large, remular, wal; nurfuer sumoth hut mot sliny;

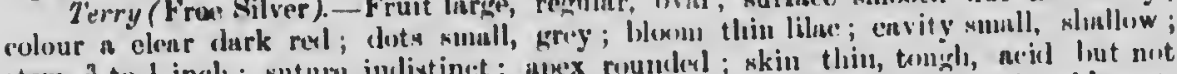
stem, so to inch; snture indistinct; upex roundesl; skin thin, tamgh, neinl lout noit astringent; Hesle firm luat melting; stone lurge', oviste, jusinturl; fluttened, arid uext, to stone, ndherent; Havour a mingling of Amerienua und Sngust ifolin; quality goxnl.

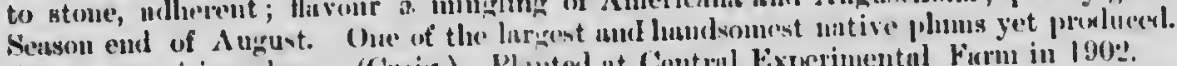
$\Lambda$ very promising plum. (C'mig.) Ploutel at Centrul Fxprinental firm in 190:.

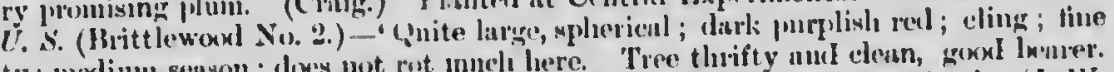

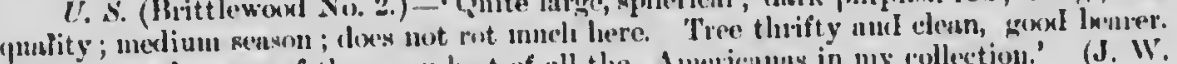
'I'lis I regard us one of the very lest of ull the Americanus in my collection.' (J. W. Kerr, lenton, M(L.)

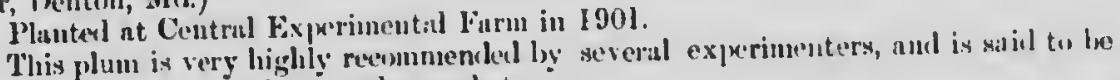

the largest Amerion nil plum on the market.

Vau Buren.-Fruit medium to alwere mediun size, almost round ; cavity narrow, sluallow; suturs only a fuirly dlistinct line; anex roumlesl; colour yellow, mone or less motterl and washed with bright red; dots numerous, small, yellow; bloom light; skin thiek, tough; thew derp yellow, juicy, firm; stone abuve micliun size, roundish, broad, mueh thattened, cling ; sweet, gond thwour ; quality guod. Sinson mid-september to October.

A lundsome plum. One of the litest and leest keepers.

Weaver.-Fruit alove medium sike, roundish, somewhat heart-shnped; maity narrow, medium deptlı; suture a distinet line ; colour yellow, nearly entirely overwprend with bright red; dots numerous, smiall, purple; blum light; skin nodenutely thirk, tough ; flesh deep yellow, juicy, sweet ; stone medium size, oval, eonsiderably tlattened, almost free; qunlity good. Season mid-September.

An attractive plum, but not lnige enough to be pronising.

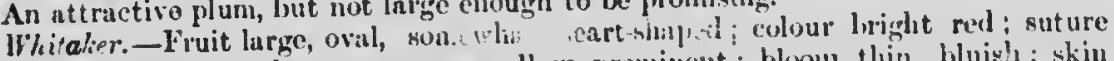
merely a distinct line; dots numerous, yellow prominent; bloom thin, bluish; skin thin, trugh ; flesh yellow, juicy, moderately frm, sweet, good flnvour; stone meelium size, long oval, eling; quality grod. Season first and second weeks in September, doen not ripen evenly. A luandsome plum. Tree vigorous, spreading und productive where fruit buds are not injured by winter. Wildgrose group.

Wolf.-Fruit lnrge, roundish; catrity narrow, shallow; suture slallow, finirly s. tinct, not deprenew; a prex rounded: colour deep real; dots filirly numerous, sli ill, yellow, distinct ; blom modemate; shin thick, tough ; the lo dep yollow, juicy, sweet, rich, good flavour; stome above molium size, outline arul, consiclevibly flattenerl, eling; quality gnoul. Seasou enrly to micl-september: One ot $\therefore$ best. 'This does not answer the deseription of Wolf given by some suthorities. lboth, however, are geod piums,

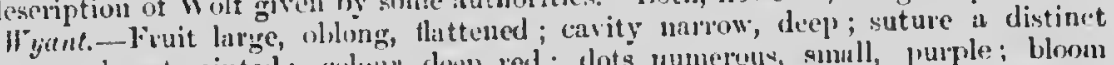

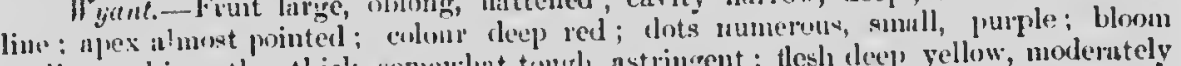
medium; slin tatlee thick, somewht temal, astriugent; tlesh deep yellow, moderutely juicr, fairly sweet; stone large, much flatened, wal. semi-cling, aluost fore; quality medium. Fianon millseptember. Quality not go.el enough. This plum is highly

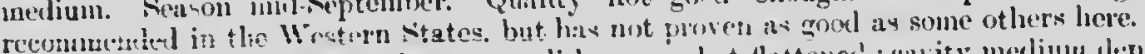

Yoxmite l'uple. - Fruit large, roundish, sovewlmt flattenec. : cavity mediun deptla

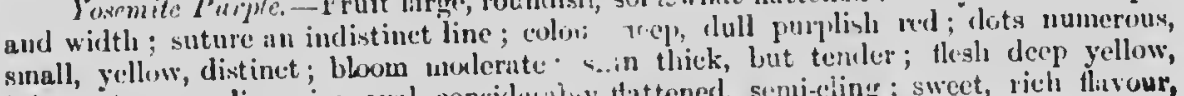
juicy ; stone uelium size, oval, consideraby thattened, semi-eling; sweet, rich flusour, but sonewliat astringent; quality above medium. Season mid to late September. 


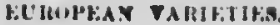

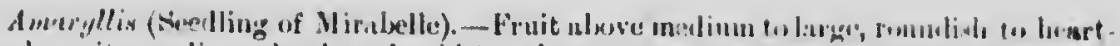

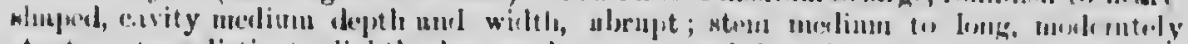

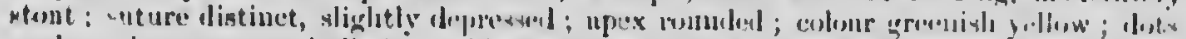

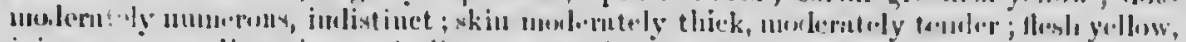

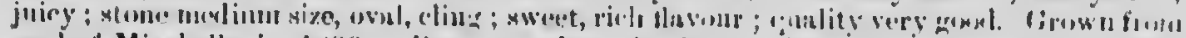

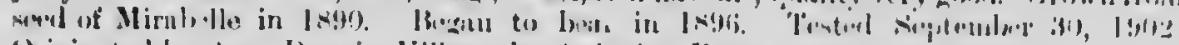

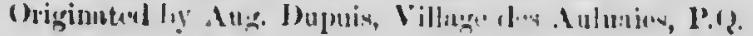

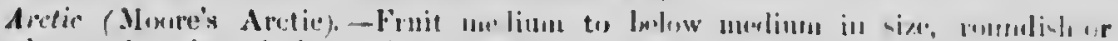

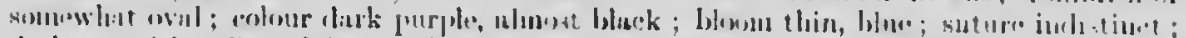

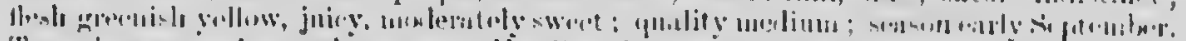

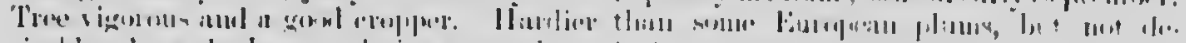

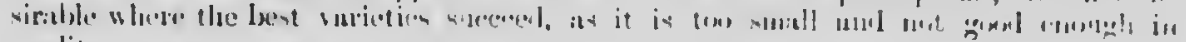
quality.

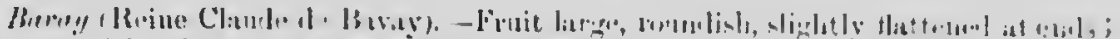

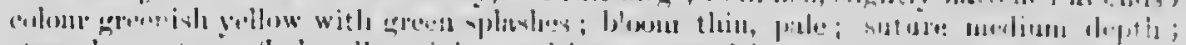

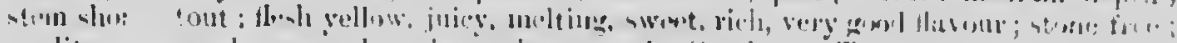

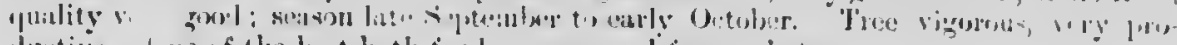

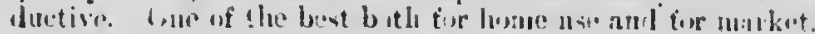

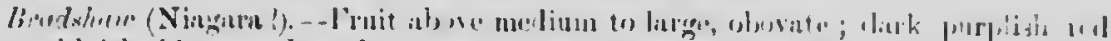

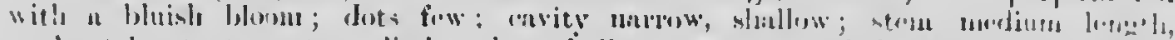

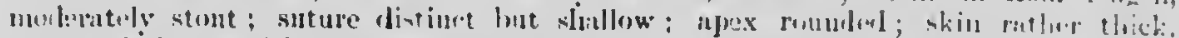

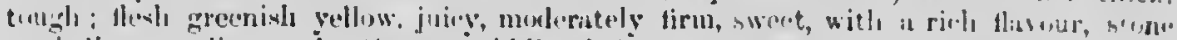

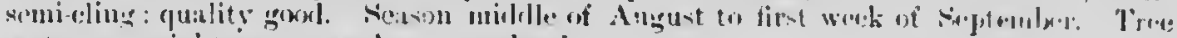
a strung upright inger in lery productive.

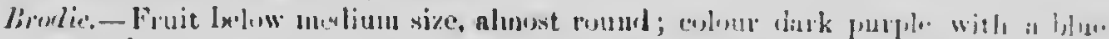

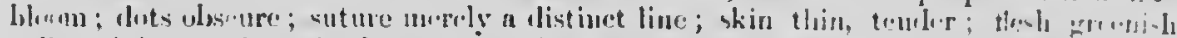

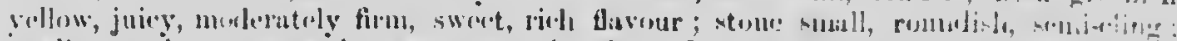

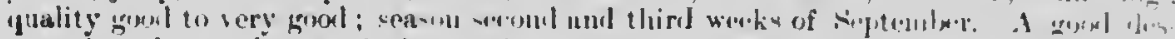

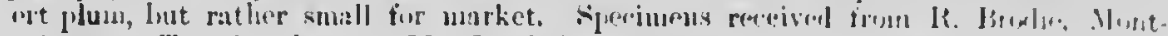

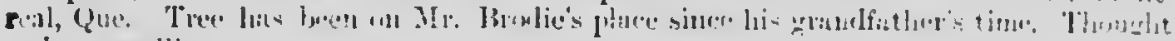
(1) ln it recolliure.

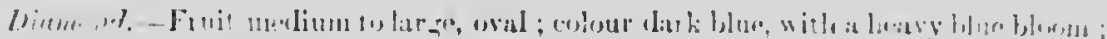

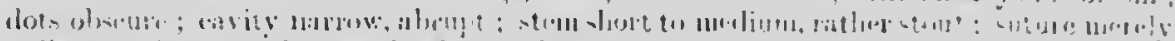

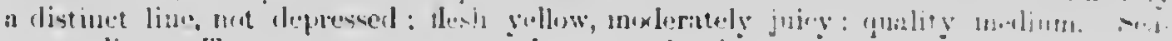

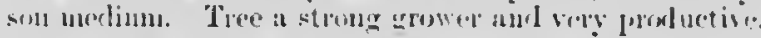

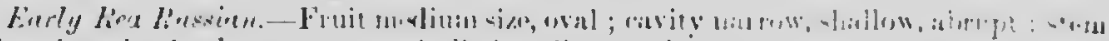

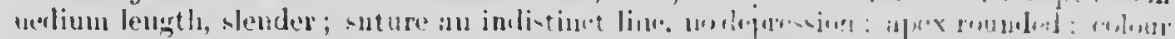

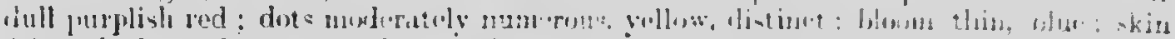

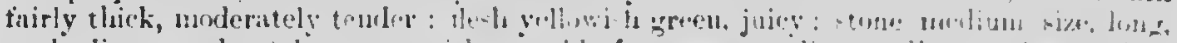

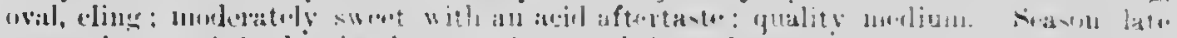

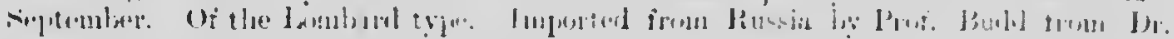

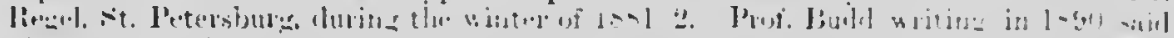

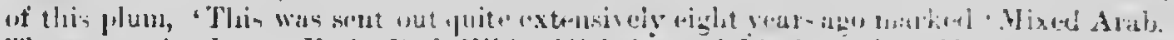

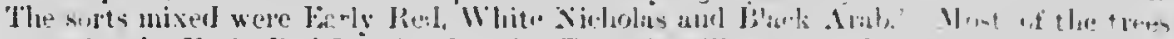

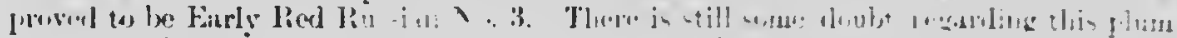

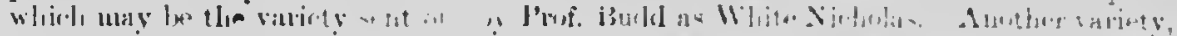

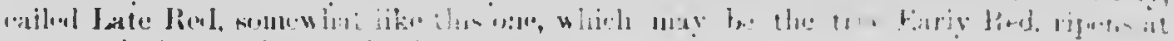

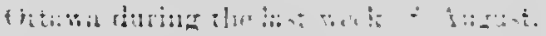

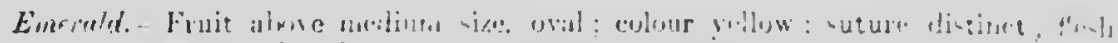

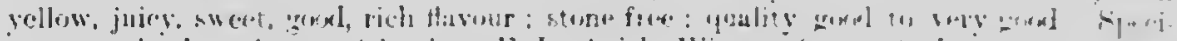

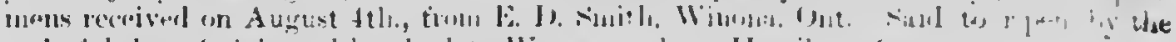

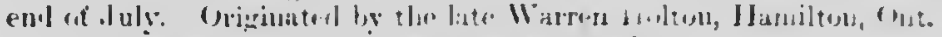

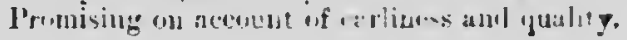


Germun Prume.- Fruit small to medium ; lung oval ; cavity very shallow ; stem rather slemler, methum long ; sut ure hardly more thin a line; apex somewhat pointed; colour blue; dots few, senttererl; bloom blue; thes greenish or slightly yellow; stono small, oval, fointerl, morlentely flattened, very free; quality harlly more than fair; season melium : tree strong, wall grower, profluetive,' (W'ugh). This has long been is popular plum.

Glews (Glass Serlling).-Fruit largr, roundish, deep punple with a blue bloom; suture very slunliow, imlistinet; stem medium length, slender; tlesh yellow with a shade of green, juiey, murlerately sweet; skin medium in thiekness, tonder; stone medium si\%e, cling; quality melium. Season second and third weeks of September. 'Tree n strong grower and pruluctive where it suceceds well. Very similar, if not identienl with Quackenboss.

Golden Drop (Cre's Golden Drop).-- "Frnit linge to very large; oval with a short neck, the two halves uneyuual; carvity very shallow and alurupt; stem medium length, stout; suture deep; apex somewhat depressel ; colour golden yellow; lots very inany, vellow; hloom yellow; thesh tirm. ineaty; stone inedium large, long, pointed, somewhit flattencil, ribbel at the edge, half free; quality good; season medium late. Tree a groud grower with large, coarse, rongh folinge.' (Waugh).

Frend Dukr.- Fruit lange to very large oborate; cavity narrow, shallow; stem

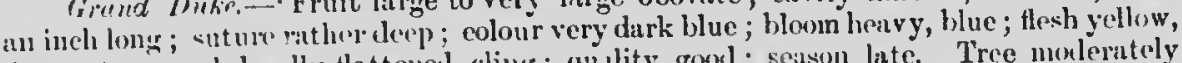
firm ; stone oval, hat lly tlattenel, ching; quility gool; seison late. Tree molemtely

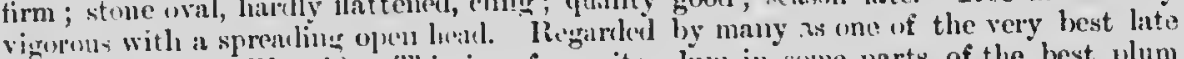
shipling plums' (Wangh). 'This is a filvourite flum in some parts of the best flum distriets of (Ontario.

Guoii. - Fruit medium siæn; wral, condate; cavity shallow : stem an inch lon: pulsescont; suture slosllow; apex semewhat pointed ; colour blue; dots not visible; bloom blue; thesh greenish yellow; stone merlium size, round ovil, obligue pointerl, eling; quality fair; seasion nedium' (Wan; gh $_{\text {). }}$.

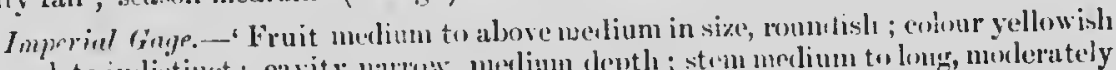

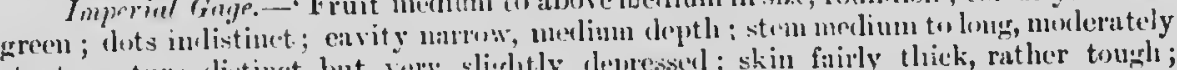

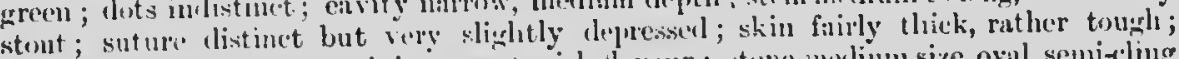

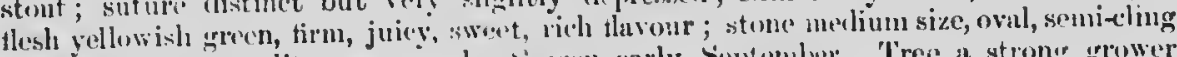

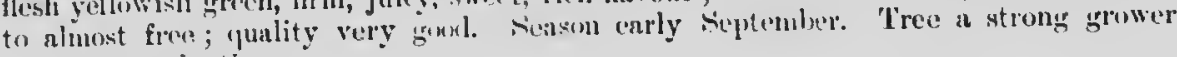
and very jughetive.

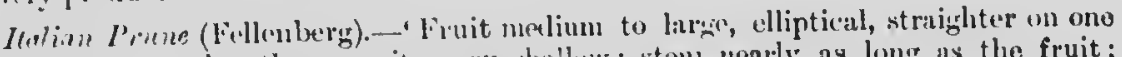
side and longer on the other ; eavity very shallow; stem nenrly as long as the fruit; suture shallow; colour dark blue; ilots inot nany, (lull yellow; hloom blue; skin thin ; flesh grecuish yellow; stone modium six, ovil, puinted, rough, rilgel at edge, quito

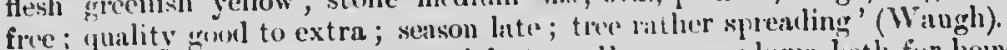

This $i$; whe of the most satisfartory litiruean plums loth for home use and for numket.

fefiprom.- Fruit medlium to large, round or round wal ; cavity very shallow; stem morlium slurt ; suture, harlly any; alex very slightly depresseel; coluur greenish yellow ; tots many, greeni-h; bloom white; skin thin and tender; tlesh yellow; stone mediun size, hlunt, with a short neck, slightly lhattened, rough, free; flavour, rich and sugary ;

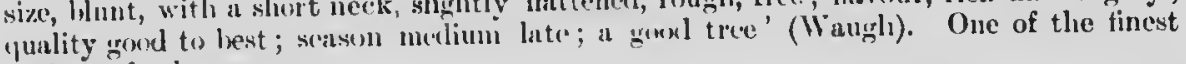
virieties for lume use.

Jomlicerd. Fruit medium siæe, oval, slightly tlattenel at ends; colour purplish red with a thin blue blom ; dots fairly numerons, yollowish, distinct; stem short, slender; suture slablow, indistinct; skin rither thin, tedules; flesh ycllow, juicy, sweet, but mot rich, fim ; stone neelium size, eling; quality melium; season seeond and third weeks of September. Tree vigurous and a very hrary benrer. One of tho hardiest of the luropean plums. 
Lunn (Montreal No. 60).-Fruit received from W. W. Dunlop, Outremont, Que.:-

Fruit large, oval, broad (round oval); cavity shallow, mediunı width, slightly flaring; sten. nedium length, $\frac{1}{2}$ inch, stout; suture a distinet line, very little if any depression; apex rounded, very slightly flattened; colour dark purple; dots fitirly numerous, irregular, indistinet, brownish ; bloom moderate, blue; skin moderately thick, tough; flesh yellowish green, very juicy, fairly firm; stone large, oval, cling; swect, rich; quality very groxi. Season curly to middle of September. A tine dessert plum.

Mfonn'ch.- 'Fruit large, rounclish oval; cavity deep, broml, rounded; stem short sa.. - tout; suture hardly visible ; colour dark purplish; bloom lieavy, bluish ; flesh yelleswis!: ; inc free; 'puality gool ; neason late. An English variety lately introdueed

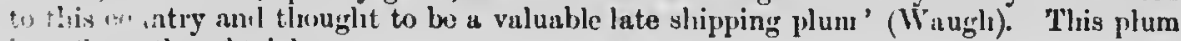
is will wertliy of trial.

Me itmorency (Reine Claude de Montmoreney). - Fruit medium size, almost mund; ca: :y narrow, alorupt, rather shallow ; stem short to medium, morlerately stout ; suture inlistinct ; sometines very slightly depressed; apex rounded or sliglitly tlattened; colour yellow and greenish yellow before quite ripe with a lirht orango blush or dots of orange on sunny side; dots obscure; bloon thin, white; skin morlerately thick, tough; flesh yellow, very juicy, molerately firm, sweet, rich; stone snall, oval, almost free; yuality very good.

Mounlain.-Fruit received from W. W. Dunlop, Outremont, Que. :-

Fruit merlium to above melium size, roundish, flattened slightly at ends; eavity medium rleptlı and wirth, slightly flaring; stem nedium to long, moxlerately stout; suture distinet, usually slightly depressed, apex slightly llattened ; colour, greenish yellow, more or less overspleat with ilull coppery res! dots numerous, ycllow, distinet; blom thin, bluish; skin molerately thick, tough; flesh yellowish green; stone above mediun, broad, roumlish, cling; swert, rich ; quality very good. Seesson carly to middle septemlur. An excellent dessert plum. Well worth propagating.

Jount Roynl (Dunlop 54).-Fruit recived from W. W. Dunlop, Outremont, Que. Fruit medium sian, roundisli, flittenerl at stem end; eavity mediun to open, mediun depth, somewhat flaring ; stem short to medium, moderately stout ; suture distinet, very slightly depresond ; apex rounded, slightity. !lattenerl ; colour dark purple; dots numerous, irregular; distinet; bloom blue, molerate; skin moderately thick, fairly ton. der ; tlesfi greenish yellow; juicy, firm, sweet, moleratcly rich flavour; ston below inedium, rounclish, cling; quality goort. Senson early to mid-September. Should tre a grorkl shipping plum.

M/clanghlin. - Fruit melium size, round or even oblate; cavity shallow, with a rulge arouml the stem; stem strong, rather long; suture very shallow; apex very slinhtly drpressed ; colour greenish yellow with a pink blu sh ; dots many, grecnish ; bloom white; skin thin; flesh yellow; stone medium size, oblique oval, slightly flattened, rough, cling; flavour rich, sugary; quality extra. Scason medium. Trec harly and a fairly goorl grower.' (W'augl).

One of the lest varieties for home use, the quality leing execptionally goot. It is of the Green Gage type.

Peters (Petcrs' Yollow Gage).- - Fruit mediun to large ; round oval ; cavity mediun, shallow, abrupt ; stem long, puleewcent ; suture shallow ; apex slightly depressed ; colour. greenislı yellow, sonnetines with a slight blush ; dots many, yellow; blown white; skin thin ; flesh wrenish yellow ; stunc medium large, oval, pointed, hardly flattened, clingr ; quality grom! to bist. Sieason early. Tree morlerately vigorous and upright. A good nnateur varicty of the Green Gage type.' (Wnugh).

This has succereled well in Distriet No. 3.

I'ond (Ponl's seolling). - Fruit very large ; nearly oval, but tapers slightly towards eavity ; colour purplish red; bloom purj.tish ; lots numerous, dull yellow, distinet lost, not prominent ; cuity narrow; slallow; sten medlum length, fairly stout; suture clistinct aur! but sliqhtly depresserl; skin thick, rather tough; flesh yellow, juicy, sweet, 
gool flavur ; stone large, rough, eling; quality good. Season early September. Tree a strong grower and quite pronluetive.

Qunckenlmss. - Fruit menlium size or larger; round ovul; cavity shallow, flaring; stem rather long; snture a line; colour blue; dots blue; bloom blue; skin thin ; flcsh greenish ; stone oval, pointcd, flattened, eling; quality fuir to good. Seuson medinn. A grod rijud growing tree and firirly proxluetive.' (Waugh).

Riprens in Onturio in second mul third weeks of September.

Queen May.-Fruit laree, roundish, almost perfectly round ; eolour gremish yollow splashed with pale green when not ripe : homm thin, pale bluish, dots small, pale, inclis-

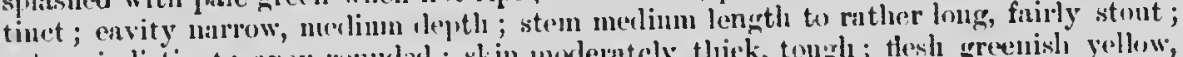
snture indistinet; apex roundal ; skin moderately thick, toung ; thesh greenish yellow;

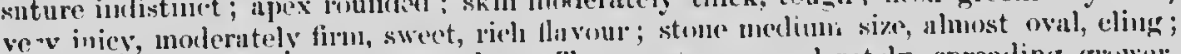
quacisy very goml ; season september. Tree a strong, miklerately spreading growere, fruiting linvily when young, but does not live very long. A very proming dessert plun. Specimens recoivel from N. W. Jack, Chateangnay Basin, Que., who is growing trees recrived from 'Thos. Clark, Cluateanguay. Thought to be a secdling.

Riryners (Dunlop 53). - Frnit received from W. W. Dunlop, Outremont, Qne. :-

Frnit above nedium to larys: oval, long, flattened on side of suture : cavity menlium deptl and width, almopt ; stem medium length, noderately stout ; sut me distinct, slightitly depressed; apex rounded; colour dark redilish purple; dots sunall, nunerous, indistinet; bloom molerate, blue; skin thin, tender ; tlesh yellowish green. firm, fairly juicy ; stone above medinm to large, iong, oval, free; mulerutely swcet ; quality abovo nedinm.

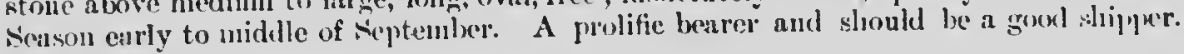
A prune plum.

Riehland.-Frnit norlium to above medinn size, oval; cavity narrow, medium depth, alorupt ; stem medium length, 3 -inch, slender ; suture a distinct line, no drepression; ancx rounded; (•nlour deep purplish red ; dots fairly numerous, yellow, indistinct ; bloom nusleratc, bluc; skin thick, finly tender; flesh grternish vellow; juicy, luoleritely firm; stone medium sizc, oral, flat, cling; ; sweet but not rich; ' puality above mediun. Season nidlle of September. IIarlier than most lunopean sorts. Griginated on the farm of Raulall When, Richland, Penusylvania.

Rouley. - Fonit alwve medimu sizc, round, dark pupplish red with a blusis bloun; dots obscure; suture an indistinct line; aj.cx ronnded; skin thin, moderntely tongh ; tlewh yellow, moderately juic, firm, swcet, rich flarour ; stone nuvlium size, oval, slightity thattemed, cling; quility gond to very nond. Season end of Alugust and first week if Sepitember. A promising seedling origrinated by Jos. Rowley, Cummings 13ridge, Ont. (near Ottawa). Said to fruit well nearly every year.

Shropshire (1) anson).- - Fruit sinall, oval : eavity, harlly any; stem about onc-lialt inch lony; suture none; colour dark blue; duts none visible; bloom blue; skin firu ; flesh greenish, sour; stone small, oval, turgid, cling; quality fair. Tree in good grower and enormususly proiluctive.' (Wangh).

This is a joprular dimson in Canirda.

Ungarish.-Fruit above medium to lirge; long oral; eavity narrow, shallow; ahrupt ; siture distinet, very slightly if at all depressed; apex round ; eolour dark purple; dots moderatelr numerous, indistinct, lirown; bloom moderate, blue; skin fuirly thick, tender; flcsli greenish ycllow, firm, fairly juiev; stone large, long, oval, free : moderately sweet; quality above mediun. Season midlle of September. Introduced by Prof. Budd from C. H. Wagner, Riga, Russia.

This plum is sourc what like the laynes (Dunlop 53)

$\Lambda$ prune plum. Promising on account if l:ardiness.

Ilaskingfor.-Fruit harge, roundish, slightitly fluttened at ends; colour greenish yellow with a pink blush on sunny side; dots obseure; cavity narrow, shallow; atem short, stout ; sutnre distinet and slightly dopressed; skin tough ; flesl grcenish yellow; firm, juicy, sweet, riel, stone medium size, roundish, almost or quite free; quality very good. Seuson early to micl-September. 'l'ree a strong grower with a roundish top. 
Lellow Egg.-Fruit large to very large, oval; colour deep yellow ; bloon white; dots simall, numerous, inclistinet; cavity shallow, ridged; stem long, moderutely stout; suture distinet, slightly depressed; skin thick, rather tough ; flesh yellsw, juicy, sweet; stone lirge, oval, eling; quality good. Season end of Aurust to carly Scitemler. 'Tres' vigorous and profluetive.

\section{JAJANFSE VARIETIES.}

Abundemon.-Fruit large, roundish; bright to deap resl with a yollow grounel lots numerous, jellow, prominent; cavity narrow, abrupt ; stem moliuu length, rathor stout; suture distinct; apex pointed; skin thin, noderately tender ; tlosl yellow, juicy,

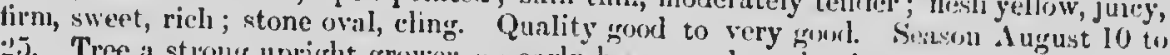
․). Tree a strong upright grower, au early bearer and proluctive.

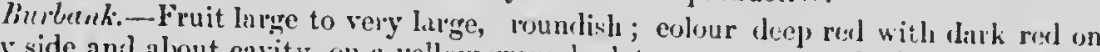
sunny side and about cavity, on al yellow ground; dots numerous, suall, distinct, y.llow; sten medium length; suture merely a distinct line; apex sometimes [niutol; skin thin, morlerately tender; flesh yellow, firn, juicy, sweet, gow flavour; shone roundi.h, eling; inality good. Season hatter part of August, a few days after Al,ani:unce. Trer: an exceptionally vigorous grower, vely branching and bears carly and luavily. OJ1\% of the

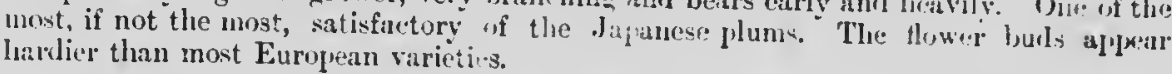

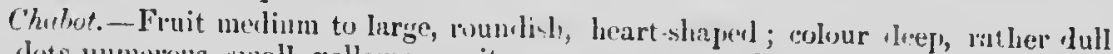
rivl; dots numerous, small, yellow; civity narow; sten short, stout ; suture fairly distinct ; a pex usualig rounded; skin moderately thick, tough, ilesh yellow, juicy, firm, sweet; stone lelow medium size, oval, cling ; quality georl. fiason litu. lice a strons upriglit grower and bears well. This variety is one of the later introluetions and hils purell one of the best of the Japanese I lami.

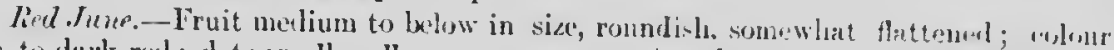

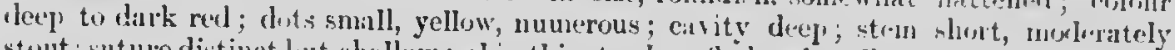
stout : snture distinet lut shallow; skin thin, tender ; flesh fale vollow, firm, juicy, lniskly

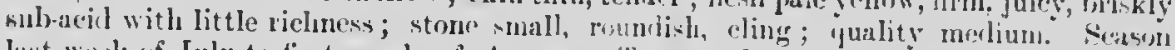
last werk of $\mathbf{J}$ uly to first week of Augu-t. Tree moleratoly yromeling. A merlium

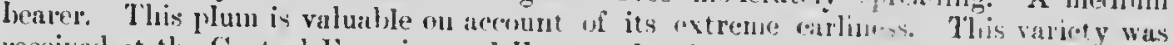

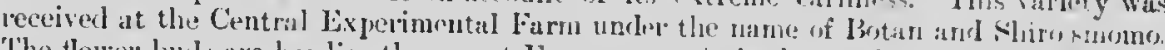

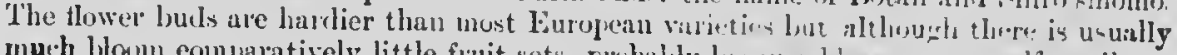

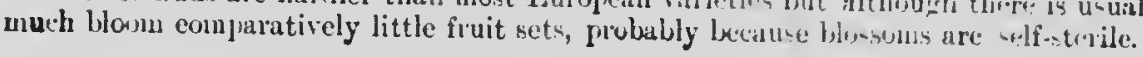


Varieties of Plums which are being tested at the Central Experimental Fatra, Ottawa

List of Varieties.

\begin{tabular}{|c|c|c|c|}
\hline Nanues of Varieties. & $\begin{array}{l}\text { Date of } \\
\text { Planting } \\
\text { Oldest } \\
\text { Trees. }\end{array}$ & Names of Varieties-Continual. & $\begin{array}{l}\text { Date of } \\
\text { Plutiutius } \\
\text { ()] lost } \\
\text { Prees. }\end{array}$ \\
\hline Ecrotreax Pleas. & & Feropeis Plums-Continued. & \\
\hline 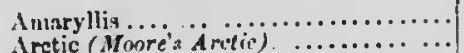 & $\begin{array}{l}1902 \\
18 ! 4)\end{array}$ & 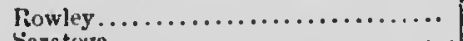 & 1903 \\
\hline 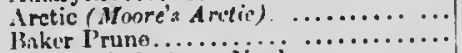 & $\begin{array}{l}18 \div 99 \\
1399\end{array}$ & 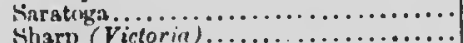 & $\begin{array}{l}1 ! k 11 \\
1 \times 95\end{array}$ \\
\hline 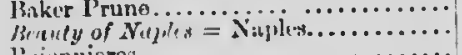 & 1399 & 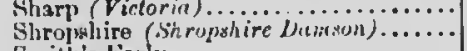 & $\begin{array}{l}1,95 \\
1898\end{array}$ \\
\hline 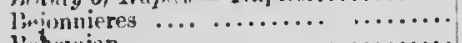 & 1901 & 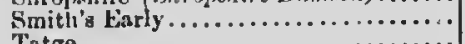 & 1847 \\
\hline 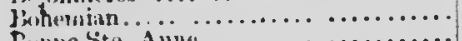 & $18: \pi$ & 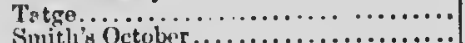 & 1903 \\
\hline 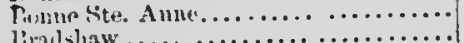 & $\begin{array}{l}184.3 \\
1 \times 99\end{array}$ & 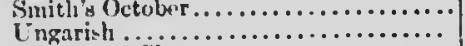 & 1597 \\
\hline 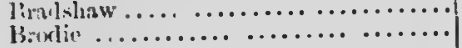 & 100,3 & 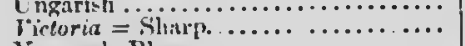 & \\
\hline Chatsugun..... & 15913 & 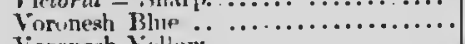 & 1903 \\
\hline 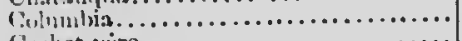 & 1,208 & Foronesh Fellow ........ & 1593 \\
\hline 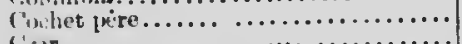 & 1901 & 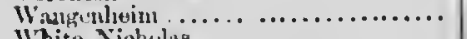 & 1901 \\
\hline ('zar............ & 1900 & White Nichulia..... & $189 ;$ \\
\hline 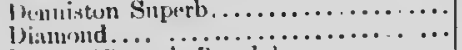 & 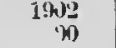 & & \\
\hline 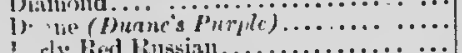 & 35 & TAPASKE PLCWS. & \\
\hline 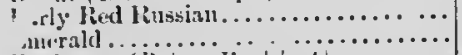 & $\begin{array}{l}1895 \\
1903\end{array}$ & Abundance & 1900 \\
\hline 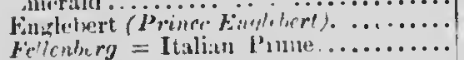 & 1898 & 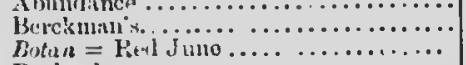 & 1903 \\
\hline 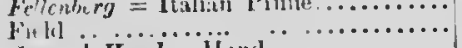 & 1900 & 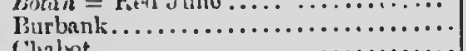 & 1900 \\
\hline 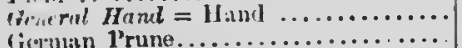 & 1895 & 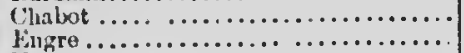 & 1903 \\
\hline 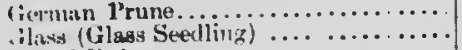 & 1893 & $\begin{array}{l}\text { Filgre } \\
\text { Hale.. }\end{array}$ & $\begin{array}{l}1913 \\
1903\end{array}$ \\
\hline 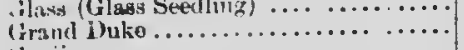 & 1898 & 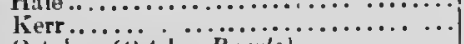 & $\begin{array}{l}1903 \\
1903\end{array}$ \\
\hline 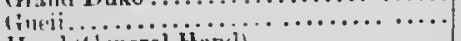 & 1898 & olwer (ietuler Purple).............. & 1918 \\
\hline $\operatorname{lan} 11 . . \ldots \ldots \ldots \ldots \ldots$ & 1898 & Red Juno................ & 1894 \\
\hline Il:mkzivetsche... & $\begin{array}{l}1900 \\
1903\end{array}$ & Burnomo $=$ Rivl Jine... & 1903 \\
\hline $\begin{array}{l}\text { llorrigan ..... } \\
\text { Ickworth } \text { fekic }\end{array}$ & 1901 & $\begin{array}{l}\text { Shiro.Smomo }=\text { Rovl Jilte.. } \\
\text { W'illard .................. }\end{array}$ & \\
\hline $\begin{array}{l}\text { Ickworth r fek } \\
\text { [minentitl Gitge }\end{array}$ & 1900 & Willare. & 190 \\
\hline Italian Prume (Fellieldrey). & 18.18 & AMRRLANA PIRMA. & \\
\hline 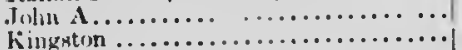 & $\begin{array}{l}18: 5 \\
1 ! 900\end{array}$ & Admiral bev & \\
\hline $\begin{array}{l}\text { Kingston } \ldots . \\
\text { Lachino } \ldots \text {. }\end{array}$ & 1903 & 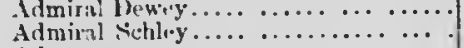 & $\begin{array}{l}1901 \\
1901\end{array}$ \\
\hline $\begin{array}{l}\text { Lachino } \ldots \text {. } \\
\text { If tjusic...... }\end{array}$ & 1893 & Advmix & $\begin{array}{l}1001 \\
1: M) 3\end{array}$ \\
\hline 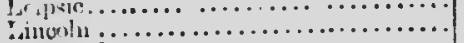 & 190 & American Finglo............... & 10.05 \\
\hline 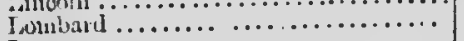 & 1900 & $y \ldots \ldots \ldots \ldots$ & 1903 \\
\hline 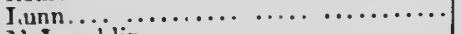 & $1: 913$ & Bunilicr............. & 1100 \\
\hline hlin $. . . . . . \ldots \ldots, \ldots$ & $19(9)$ & 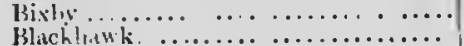 & $\begin{array}{l}18: 43 \\
18 ! 93\end{array}$ \\
\hline 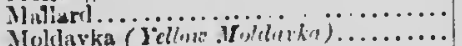 & $\begin{array}{ll}1 ! 103 \\
1 \times 97\end{array}$ & 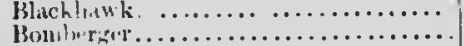 & $\begin{array}{l}18 ! 93 \\
1 ! 01\end{array}$ \\
\hline 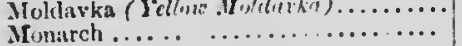 & 1906 & 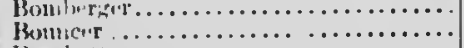 & $1 \times 95$ \\
\hline 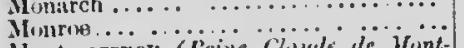 & 1901 & Biractirtt $\ldots, \ldots \ldots \ldots \ldots \ldots \ldots \ldots \ldots \ldots \ldots \ldots \ldots$ & 1903 \\
\hline 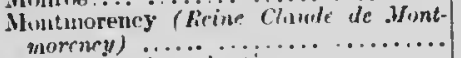 & 1899 & 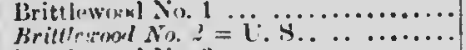 & 1901 \\
\hline Moorr's Arelic $=$ Aretic ................. & & Birttllowixnd No. $3 \ldots \ldots \ldots \ldots \ldots \ldots \ldots \ldots \ldots$ & 1908 \\
\hline 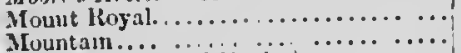 & $\begin{array}{l}1903 \\
1903\end{array}$ & & 1903 \\
\hline $\begin{array}{c}\cdots \cdots \\
\cdots \cdots\end{array}$ & $\begin{array}{l}1903 \\
1500\end{array}$ & 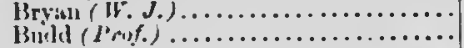 & $\begin{array}{l}1903 \\
1903\end{array}$ \\
\hline $\begin{array}{l}\text { Nisples (Braut } \\
\text { Niagara (Bra }\end{array}$ & $1 \times 98$ & 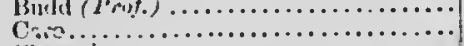 & 1805 \\
\hline $\begin{array}{l}\text { Niagara (Brat } \\
\text { (Jutivanont }\end{array}$ & 11003 & 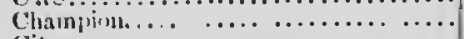 & 1835 \\
\hline$\cdots \cdots \cdots \cdots \cdots \cdots \cdots$ & 1903 & City $\quad \ldots \ldots \ldots \ldots \ldots \ldots \ldots \ldots$ & 1895 \\
\hline Pond (Pond's sivallim. & 1000 & 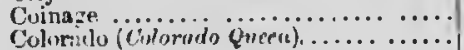 & $\begin{array}{l}1903 \\
1845\end{array}$ \\
\hline Prince Englebert $=\mathrm{l}$ & & 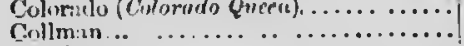 & $\begin{array}{l}1896 \\
1901\end{array}$ \\
\hline & 19003 & Confurt .............. & 1843 \\
\hline 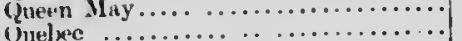 & 1909 & Cunsul............... & 1895 \\
\hline $\begin{array}{l}\text { (juelere } \\
\text { Hayne }\end{array}$ & 193 & Cottrell. $\ldots \ldots \ldots \ldots \ldots \ldots \ldots \ldots \ldots$ & 1895 \\
\hline 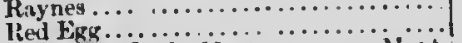 & 1898 & 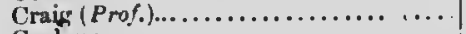 & 1903 \\
\hline Reine Clerude de arontmercme!l Mlost. & & 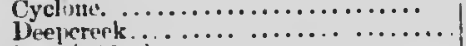 & $\begin{array}{l}1901 \\
1805\end{array}$ \\
\hline Richard frut:er. & 1895 & Dennis $\left(H r_{0}\right)$. & 1845 \\
\hline Kichland....... & 1888 & De sutu............................ & 1883 \\
\hline
\end{tabular}


List of Varieties of Plums.

\begin{tabular}{|c|c|c|c|}
\hline Names of Varictins-Con'inued. & $\begin{array}{l}\text { Date of } \\
\text { lyinting } \\
\text { Oldast } \\
\text { Trted. }\end{array}$ & Names of Varieties-Cmlinued. & $\begin{array}{c}\text { Date of } \\
\text { Planting } \\
\text { Olukes' } \\
\text { 'Prits. }\end{array}$ \\
\hline Asmutciss Pusm--Continued. & & Ambricisid Pross-Concluded. & \\
\hline 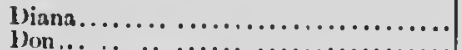 & 1901 & Yalue........ & \\
\hline 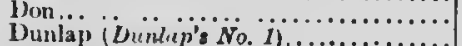 & 1895 & 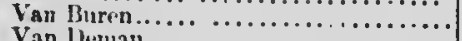 & 1890 \\
\hline 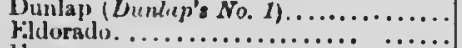 & $189 i$ & 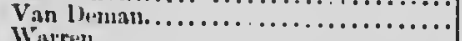 & 1,495 \\
\hline & $\begin{array}{l}1901 \\
1901\end{array}$ & 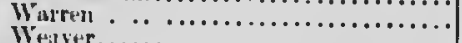 & 1,01 \\
\hline 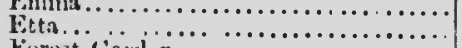 & $\begin{array}{l}1901 \\
1901\end{array}$ & 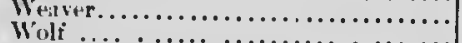 & 1893 \\
\hline & 1894 & $\cdots \cdots \cdots \cdots \cdots \cdots \cdots \cdots \cdots \cdots$ & 1888 \\
\hline 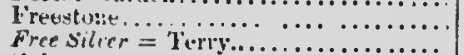 & 1901 & 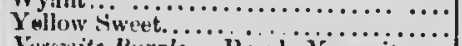 & $\begin{array}{l}1890 \\
1895\end{array}$ \\
\hline 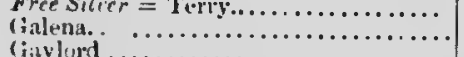 & 139.5 & Fusemite Purple = Purple Yost mite... & \\
\hline 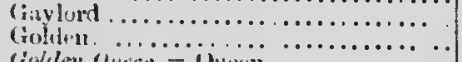 & $\begin{array}{l}16 \% 5 \\
10: 3\end{array}$ & Nighs Plims. & \\
\hline 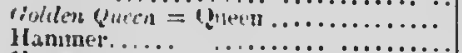 & & litkin $\ldots .$. & 1897 \\
\hline & $\begin{array}{l}1515 \\
1.01\end{array}$ & 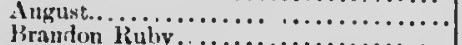 & 1093 \\
\hline Hitwk,ype..., & 1598 & 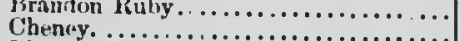 & 1903 \\
\hline IIslt. $\ldots \cdots \cdots \cdots \cdots \cdots \cdots \cdots$ & 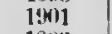 & 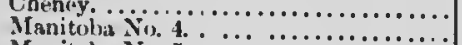 & 1890 \\
\hline 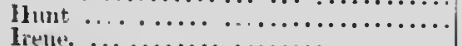 & 1893 & 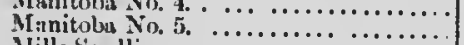 & 1895 \\
\hline 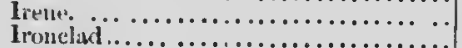 & 1495 & Mills Seerlling. & 1895 \\
\hline 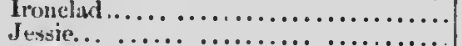 & $1 \times 15$ & 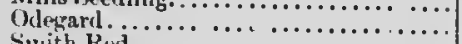 & $\begin{array}{l}1890 \\
1901\end{array}$ \\
\hline 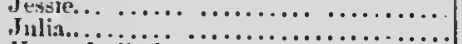 & 1894 & & 1300 \\
\hline 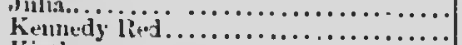 & $\begin{array}{l}1901 \\
1857\end{array}$ & 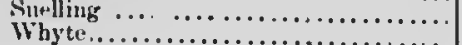 & 1894 \\
\hline Kieth. & $\begin{array}{l}1847 \\
1903\end{array}$ & 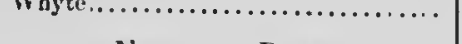 & 1893 \\
\hline 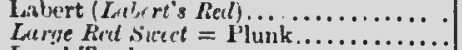 & $18: 7$ & MIXER-LIKF: PLtMS. & \\
\hline 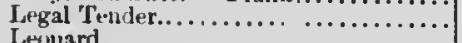 & 1901 & Carver............ & $14 ! 5$ \\
\hline$\ldots \ldots \ldots \ldots, \cdots \cdots$ & 1897 & 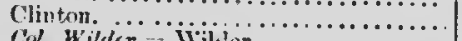 & 1895 \\
\hline 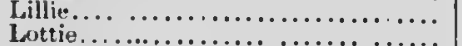 & 1901 & 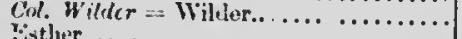 & \\
\hline 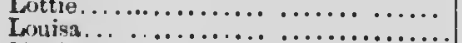 & 1901 & 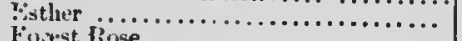 & 1895 \\
\hline Mlunliato.. & $\begin{array}{l}1901 \\
180 \%\end{array}$ & 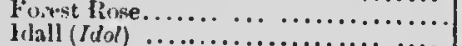 & 1898 \\
\hline 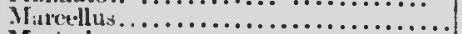 & $1: 01$ & 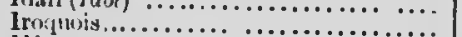 & 1895 \\
\hline Majorie.... ... ................... & $1: 03$ & $\begin{array}{c}\cdots \\
\cdots\end{array} \cdots \cdots \cdots \cdots \cdots \cdots$ & 1893 \\
\hline$\ldots \ldots \ldots \ldots \ldots \ldots \ldots \ldots$ & $19+1$ & 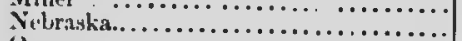 & $\begin{array}{l}1895 \\
1895\end{array}$ \\
\hline$y \cdot \ldots \ldots \ldots \ldots \ldots \ldots$ & $1 ! \% 3$ & (Yr+n: $: \cdots \cdots \cdots \cdots$ & 1890 \\
\hline . $\ldots \ldots \ldots \ldots \ldots \ldots \ldots \ldots \ldots \ldots$ & 19311 & Prairit Flower. & 1845 \\
\hline 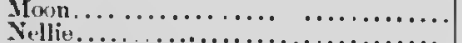 & $18 ! 93$ & 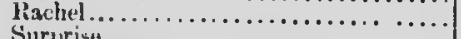 & 1897 \\
\hline 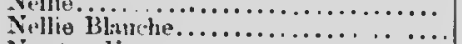 & $\begin{array}{l}18: 5 \\
1901\end{array}$ & 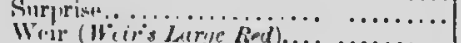 & 1900 \\
\hline 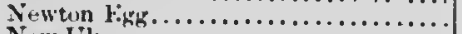 & 1807 & 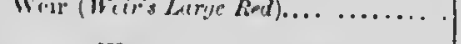 & 1895 \\
\hline New Ulm........................ & $1 \times 43$ & 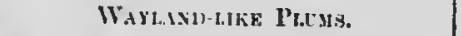 & \\
\hline 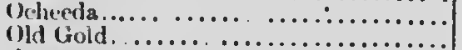 & $189 \%$ & & \\
\hline 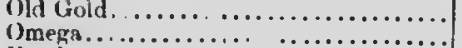 & $\begin{array}{l}189 \pi \\
1901\end{array}$ & 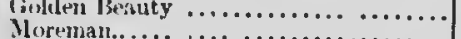 & $18.4 \pi$ \\
\hline $\begin{array}{l}\text { Omega } \ldots \ldots \ldots \ldots \\
\text { Pearl }\end{array}$ & $\begin{array}{l}1901 \\
1 !(n) 1\end{array}$ & 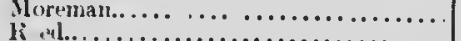 & $18 \times 3$ \\
\hline 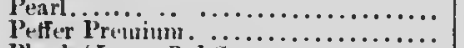 & $\begin{array}{l}19 n 1 \\
180 ! 5\end{array}$ & 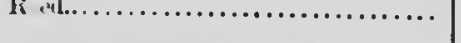 & $1 \times 95$ \\
\hline 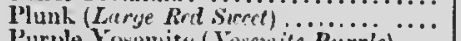 & 1897 & Wil.tuoosk PLusis. & \\
\hline 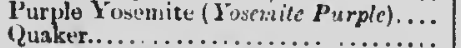 & 189.5 & Zharlas & \\
\hline 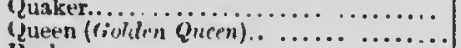 & 1901 & 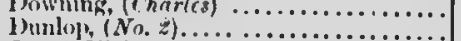 & 1893 \\
\hline 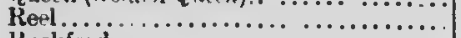 & $1 ! \omega 1$ & 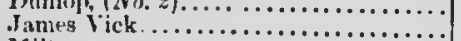 & 1895 \\
\hline ................ & 1592 & 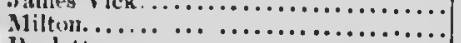 & $\begin{array}{l}1897 \\
1893\end{array}$ \\
\hline 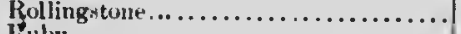 & 1,888 & 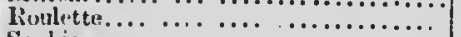 & 1999 \\
\hline$\ldots \ldots \ldots \ldots \ldots \ldots$ & 1903 & Sophin....................... & 1885 \\
\hline $\begin{array}{l}\text { Sada } \\
\text { Silas vilison. }\end{array}$ & $1: M 1$ & $Y$ an Honten...$\ldots \ldots \ldots \ldots \ldots \ldots \ldots \ldots$ & 1901 \\
\hline Smith....... & 1901 & 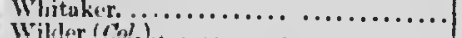 & 1895 \\
\hline Simar........ & 1888 & 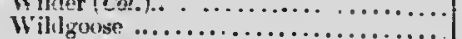 & 1041 \\
\hline & 1903 & Hen. & $18: 15$ \\
\hline Stodilard.. & 1891 & IIrbain Plesss. & \\
\hline 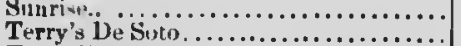 & $\begin{array}{l}1895 \\
1903\end{array}$ & Americi (Botan & \\
\hline 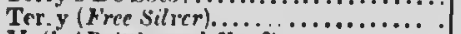 & 1902 & Ames $(P$. Americana $\boldsymbol{X} P$. tritora) ...... & $\begin{array}{l}1 ! 901 \\
1901\end{array}$ \\
\hline U. S. (Brittlerond No. 2)............... & 1001 & Apple (Parentage unknown)............ & 1401 \\
\hline
\end{tabular}


List of Varieties-Concluded.

\begin{tabular}{|c|c|c|c|}
\hline Nanses of Varictie-Continued. & $\begin{array}{l}\text { Date of } \\
\text { Plsnting } \\
\text { Oldest } \\
\text { Trees. }\end{array}$ & Naunes of Varieties-Concluded. & $\begin{array}{l}\text { Uate of } \\
\text { Ylantiug } \\
\text { Olklest } \\
\text { Trees. }\end{array}$ \\
\hline 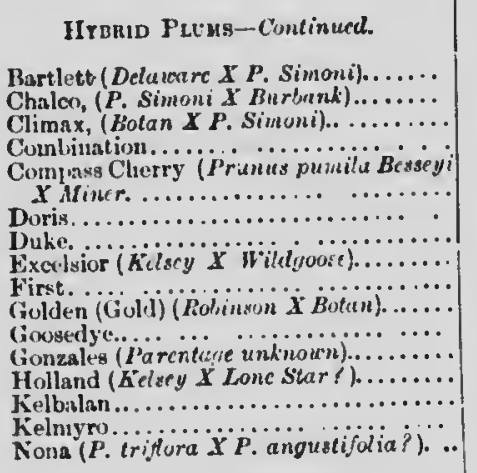 & $\begin{array}{l}1901 \\
1903 \\
1901 \\
1 ! w 3 \\
1901 \\
1901 \\
1903 \\
1903 \\
1903 \\
1903 \\
1903 \\
1903 \\
1903 \\
1903 \\
1903 \\
1903\end{array}$ & 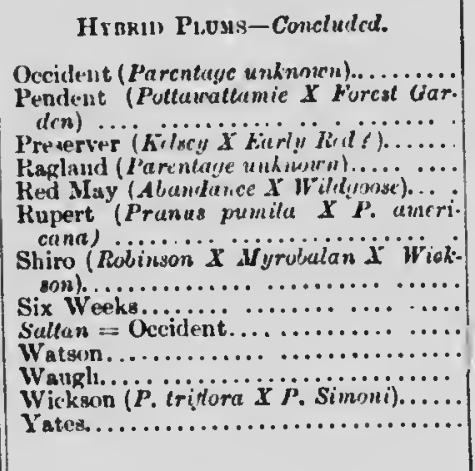 & $\begin{array}{l}1903 \\
1901 \\
19103 \\
1903 \\
1903 \\
1901 \\
1901 \\
1903 \\
1901 \\
1903 \\
1903 \\
1903 \\
1903\end{array}$ \\
\hline
\end{tabular}

\section{POL.INATIO. OF PLUMS.}

Until quite recent years the pollination of fruits was given companitively littl: study, but during the past ten years a number of exprimenters have been at work investigating the enuses of failure in the setting of fruit and have shown the inportance of linving the blossoms fertilized by pollen which will ensure the setting of the fruit. The pluin has received more careful study in regard to pollination than any other fruit. For five years or mors Prof. F. A. Waugh gave this question his specinl attention, and the results which lic obtnined and the facts which he published liave been of great assistance to fruit grower's.

As a result of his experinents he found that of all the varietics of plums of American origin which he studierl (and he studied inost of those ou the market), only one variety, the lhobinson was self-fertile. In other words, if a tree of any other variety of American origin than the Robinson were planted where its flowers could nct be fertilized hy the pollen from a tree of another variety no fruit or practieally no firuit would set. The Japaneso plums were almost as self-sterile as the American, but the European plums were more or less self-fertile. It will be seen from the alove that many varieties of plums are not fertilized at all or only partly fertilizeal by their own pollen. It is necessary, therefore, that varieties be so uixed in the orclard that proper pollination and a good setting of the fruit will be ensured. Americana varieties of plumas should be planted to pollenize Anerienna varicties, Nigra to pollenize Nigra, although Amerieana will dn, Japranese to pollenize Japanese anrl European to pollenir. European. Varicties should le planted near each other which bloom at the sume tinke. This is very important, as if the valrieties do not bloom at the same time pollination cannot take plice. 'The nurserymen do not as a rule wive in their eatalogues the r. lative time of blooning of the different varieties bought from them, but it is necessiry for the fruit grower to know this before planting if lie is to whtain the beat resultin. The value of bees and other insects in theorchard for assisting in pollenizing the flowers cannot le over-estimated, and where possibls, colonies should be kept for this purpose.

The dates of blooming of plums in different parts of Canada were recreded by fruit growews for the Horticultural divis:on of the Central Experimental Furm for five ycars. These dates have been compiled and the average of each variety thus obtained. 


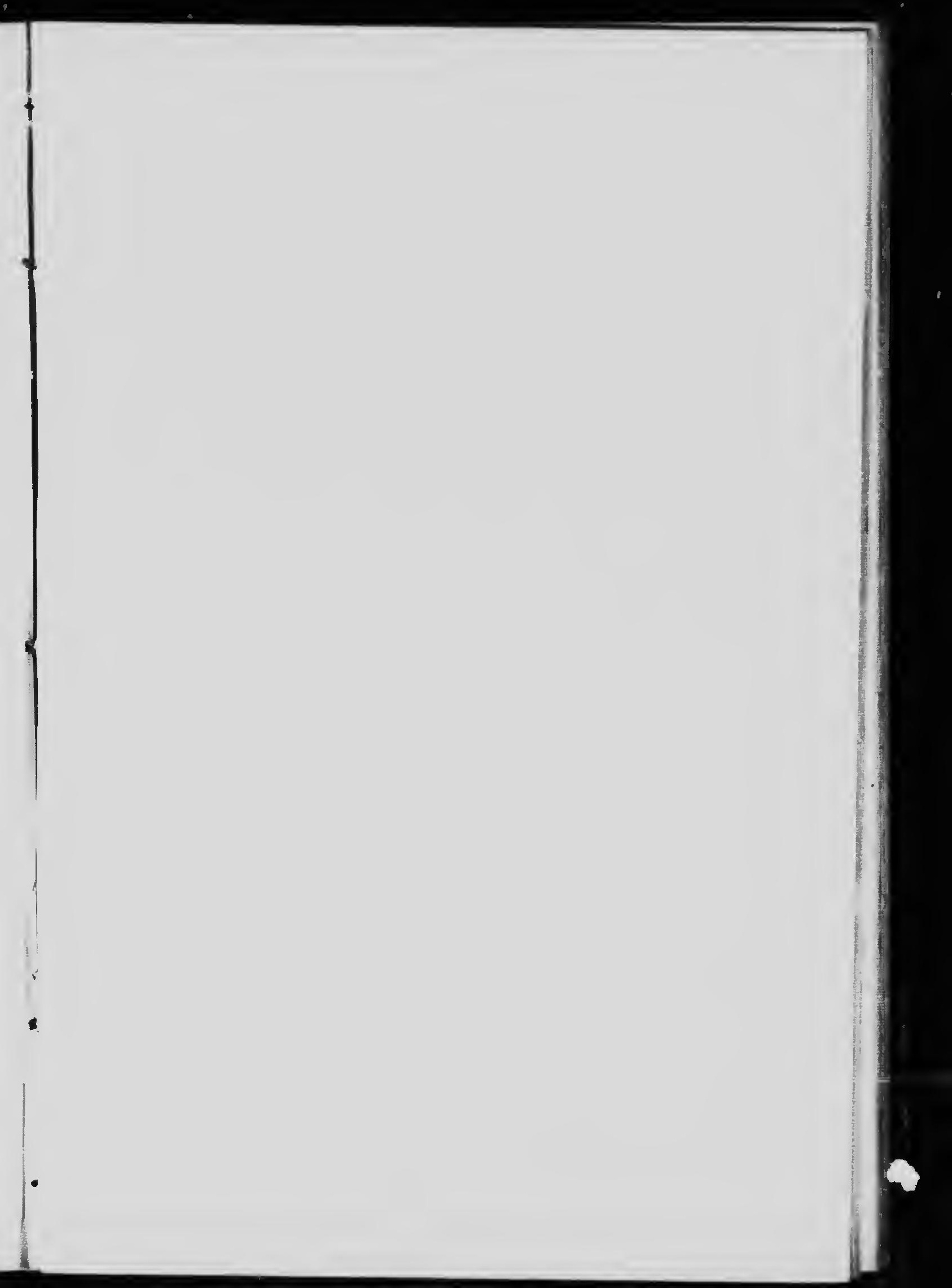




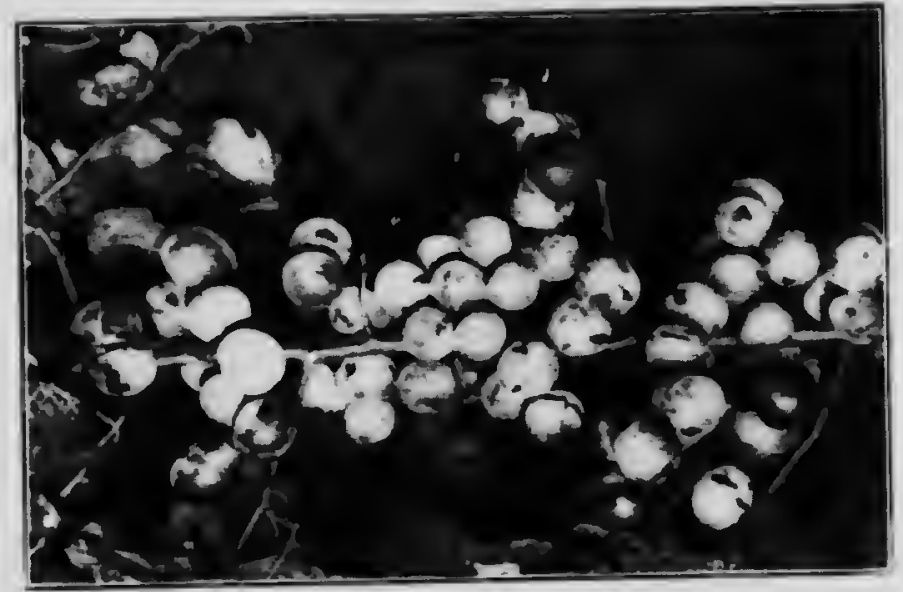

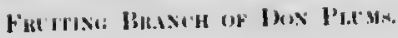

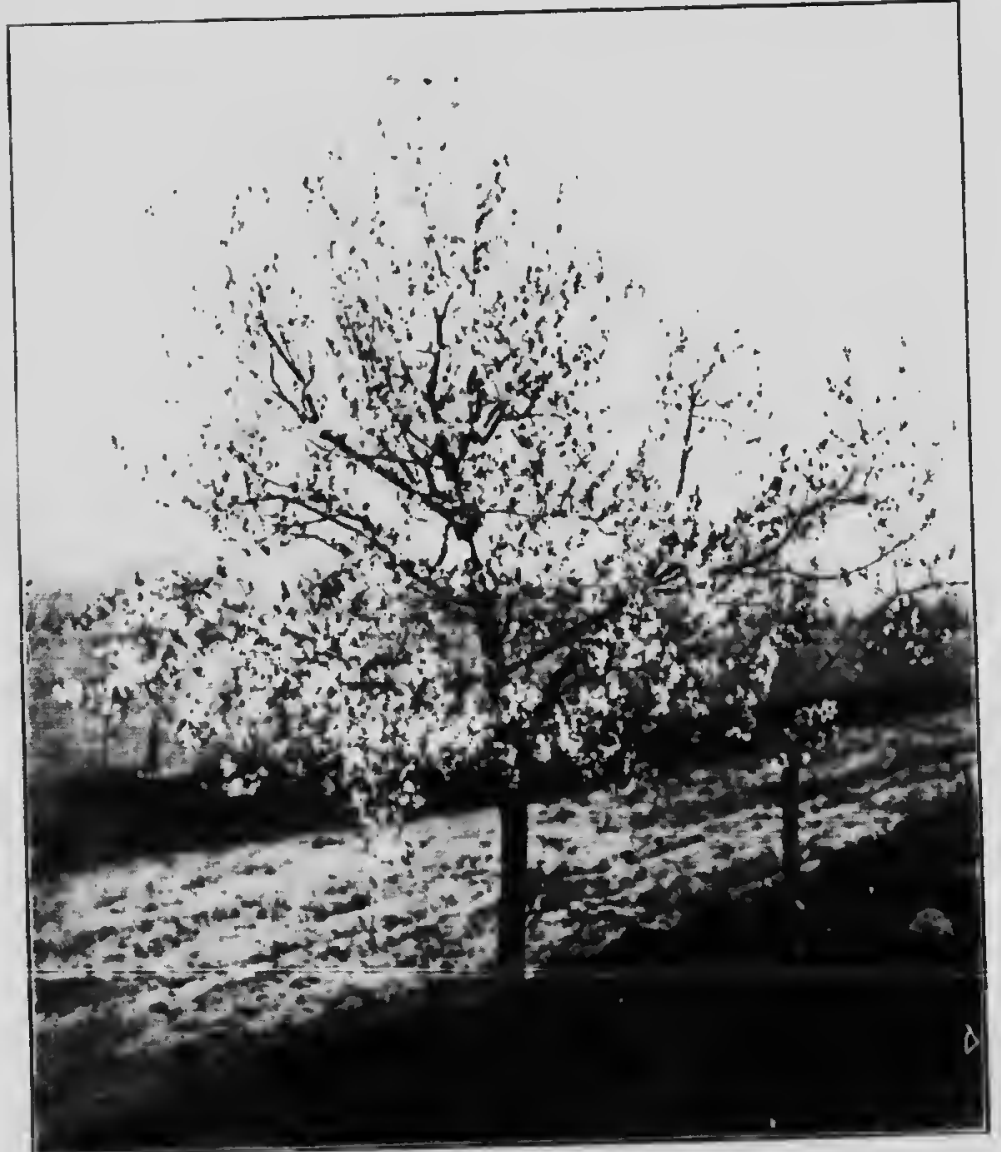

Consti J'Ley is Bhoos-Typical Tree of Prunus Niyra. [p. 32. 
The following is a table of varieties of Americana and Nigrn plums mentioned in this bulletin, giving their season of blowning. This will ls: of aswistance to fruit growers when planting. A table of the Europen varieties is not viven, as the information olitained was not full enougl, to le perfectiy relialic, and fulthermore the internixing of liorenean kimls is not so important as with Americun, as most of the varioties

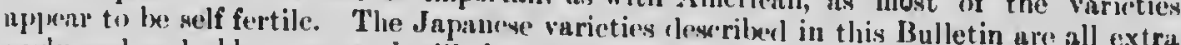
(anly ancl early bloomers, and will thus pollenise one nnotler.

'l'here is teu disy' difference between the time of blooming of the earliest and latest varicties in the following table, so that it would be unpessible for the early blooning varieties to jollenize the lat ones, but the enrly might pollenize the mediun, the mediun the medium late, and the liatter the late.

AMFIRIINA AVI NIEILA PLCNS-SEASOS OF HLOONINO.

Lirtra Early.-Aitkin.

Lurly.-Clieney, Mankato, Oregarl.

Mediım.-13ixby, Bhuncer, City, Comfort, Gaylorl, New Uhn, Ocheeda, Queen, U.S., Van Buren, Weaver.

Nedium Late.-Bender, Cottrell, Suith, Wolf, Wyant. Late--American Eagle, De Suto, Forest Garten, Hammer, Hawkeye, Quaker, Silas
Wildu, Stoddurl.

PRLNINi:

The pruning of the trees is not neilly as important in the eulture of the plum as of the apple, and there is more danere of injury by over-pruning. While an apple tree will, as a rule, recover from severe pruning, plum trees often never recover from it. In plum culture it is mucl better to err on the sicle of under-pruning thin over pruning. The tree should bo pruned when young to a symmetrical top with the main branclies so disposed that there will be no lad eroteles, after which very little pruning is nceessary beyond entting ont dead and broken branches and thinning out where thro top is very thick. Somc varieties will rejuire more pruning than otliers, sone of the Japanese leeing esprecially rampant growers. There is a difference of opinion and a difference of results in regarel to the hending back of plun trees. As a rule, very goul lesults will be obtainel without leading back. A few strong growing rariotirs, such as liurlonk, liowever, have to lre kept eut back to keep thent within reasonable limits. When trees are header in, the work should be clone early in the spring, at which time the ordimary proning ean be done to best arlvantage. Wounds slould be covered with lesul puint or srafting wax.

The fullowing note on useful fertilizers for the plun areharol has leen prepared for this bulletin by the Chemist of the lixperimental Farus.

\section{FEFTILIZERS FOR THE PLUM ORCHARD.}

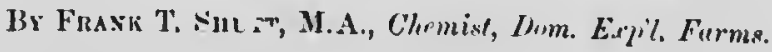

In common with other orchard crops, the requirements of the plum tree, us regards plant forl, are chiefly nitrogen, plospluric ac:d, and potasl, and these essential clements innst le present not on'y in tili quantities but in more or less re..dily a vailable forms if vigorous growth and an abunclance of fruit are to be expeeted. In ardition, lime is frequently of valuc, sinee all stone fruits make a considerable clenmnd upon the availahe lime of the soil, nnd this, owing tas natural causes or exlaustive crop-
ping, may be reclucerl to mere traes.

Further, all rational systems of fertilization must inelude the renewal, from time to time, of the vegretable organie matter of the soil, and this may best be attained when the supply of barnyart manure is insullicient, by the glowtl and tuming under of green
crops. 
Nitrngen and Organic Matter.-Sinee these, from an agricultural print of view, are intimutely associated the one with the other, the latter being the natural eonservatos of the former, and conony, as a rule, dictating their use in orchards in such an associated form, we inay conveniently eonsiler their applicution under the sane healing.

Barnyarl maure undoubtedly stands tirst on the majol ity of firms for enriehing 1.e soil in these constituents and improving its phyuical condition. In compositionund henee in vuluc - it is extromely varialsle, but gooul averuge samples of fiesli munure may le conxilerel to enutain: nitiogen $0.5 \%$, phosphorie acid $0.25 \%$ putayl $0.45 \%$. The organic matter in fresl munure is ns,mlly in the neighlourhoxl of $25 \%$.

With many oreharlists, howeve, the available supply of manure is insutlicient and inadeyuate $\mathrm{ft}_{\mathrm{f}}$ : the aren to bo fertilizeml, and it is for such that the system of green manuring - as by the growtl and tuining under of a eover crop-is especinlly valualle. The important mole of the cover rop in the morlern systems of oreluarl soil management is set forth in another plise in this loulletin and the whole subject of inerensing fertility by means of clover has ieen very fully explaned in liulletin No. 10 of the Experimental Furms series. It will, therefore, only le neceswary here to state one or two of the principal reasons why elover or some other of the lengumes should be emplosed for this purpose of enriching and improving the soil.

A rigurous enop of clover will eontuin at a moderate extinnte, in its folinge and roots :--

$$
\begin{aligned}
& \text { Nitrogen............ from } 100 \text { to } 150 \text { llos per acre. } \\
& \text { Plusplunic acil.......... " } 30 \text { to } 45 \text { " } \\
& \text { Putasls............ " } 85 \text { to } 115
\end{aligned}
$$

It is evirint, therefore, that by this nse of clover we ean with a single crop furnish thy soil with as much nitrouen as would be suppliesl by a dressing of 10 tous of manure per nele. The armater part of this nithogen is iaken by the clover from the ntmosphere, ond hener is a distinct aldition to the soil. The plosplantic acid, potush and lime, it is ic, have ben obtringl from the soil, but lave largely leen drawn from in eorsiderable pth and hence increstse the stores of these elements in the apler layers of the suil. Jloreover. the decay of the clover setw free all these inportant clements of plant fornl in formes madily utilizible by trees.

One or two worls shonld also be ulderl regardiug the value of the organic mattor so supplierl. This eventully is couverted into humus, the importance of which as a soil constituent it is ditlicult to over-estimate. It not only lilerates slowly and eontinuonsly

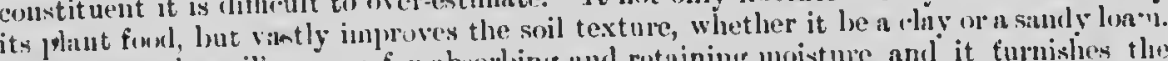
It increases the soil's juncer for aborling and rotaining mosture and it furnishes the best material for the deselopment of mierohic lifo, which, as now kmown, plitys so important in part in increasing a soil's fertility.

There is, of course, a possibility of ton great an enrichment with nitrogen by this means: this would be inclieated by luxurious and exceswive growth, dirk areen foliage and poor fruiting. Lniler such eircumstumes, the nse of organic and nitrogenus fertilizers should be dis:-untinued.

To furnish immerliately arailable nitrogen to young trees showing a clofieiency of this element (indicated ly a sparse develngment of folinge of a yellowish-green colour), nitrate of soda may lee useil as a top dressing, at the rate of 100 to $200 \mathrm{lbs}$. per nere.

Phospheric Acin, Potash and Lime.-There is prolably no better merliun fos supplying these clements to orelined soils thin unleacherl luivlworkl ashes. These slonld contrin fron 5 to 6 per eent of potrsh, in the neighbourhoul of 2 to 3 per cent of plowphorie aeid, and from 30 to 35 per cent of lime. Not only are these eonstituents in wood ashes in a condition that renders them readily assimilable, but in many parts of Cinnala they are cheaper thas in any other form of commorcial fortilizer. Fifty to eighty buslicls per aere is the nsual npplieation.

Bone meal should eontain from 3 to 4 per cent of nitrogen, and 20 to 24 per cent of phosploric aciul. Since its plant food in only slowly libernted in the soil, it is consillered a 'lasting' fertilizer and one well solnpted to orchard use. The nppliention is usually about 300 llss. per acre. Superphosphate w:!l eontain from 15 to 20 per ceat of phos. 

phorie acid, the greater portion of which should be in soluble (availablo) condition.
The npplication is from 200 to 400 lber. per acre.

Pritash can be olstained in the form of murisic: i50 per cent actual protash) or as kainit (12 per cent actual potash); 100 to $150 \mathrm{ll}$ w of the tormer and 200 wo 500 lbs. of the latter nre the limits for ordinary application.

Voorliees, in lis work on fertilizers, suggests the following mixtures for orcharls: (a) ono part, or $100 \mathrm{llws}$. each, of grounl bone, superplowphate, aul unuriate of potash :

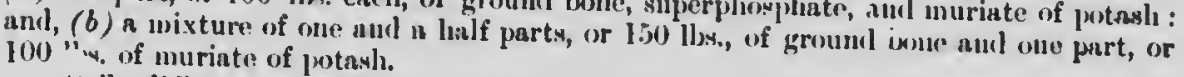

Foils difler so grently as to their fortility that it is impossilsle to stnte definitely thr. anounts of these tertilizers that eoull in all eases bo usml with profit. From 300 to $700 \mathrm{lhs}$. of sueh inixtures per acre on fairly goorl soils would, no duulst, los ample, but on very porr suils these anounts, sccorling to tho experience of many oreharlist might
be considerally increased. lime. - Where lime only is renuired, by renson of natural deficinene in this element,

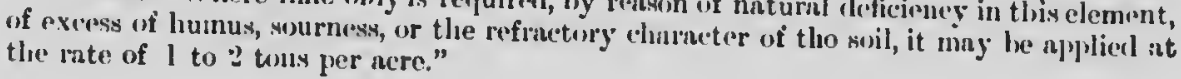

C( I ATION.

Plum orchis des should le kept uncler a high state of cultivation or otberwise the fruit is likely to $x_{x}$ small. The surfice suil should be stirred alout once n week or after "vory henvy rain until July in order to conservo moisture and to open the woil so that the air enu get in freely and assist in nitritication and help promote a thrifty growth of the trees. Trees somtimes prouluec gool crops of pluns when they are growing in sorl, but this is not the rule. It lass been fouml that there is more than twice as much moisturc when the ground is cultisated than where there is sol. Furthrmore, tho curculio lecomes very troublesome in sorl orchards, and for this rmason, if for no other, the orcha:d should le kept cultivated. Cultivation should be diseontinued towarls the wirldle of July, in order tiant the wool may ripen in goxl time and that a quenl cover crop may be estal,ished. Where trees are planted elose and cultivation is dillicult it will lyo preferable to muleh the trees with prass or straw then to leavo them in sod as the truit
will be larger and the trees more thrifty.

\section{cover chops.}

A erver crop is a crop of some kind the seed for which is planted for the pus xuse of laving, a growing crop in the orhard after cultivation las ceased, in order to help use up flint fool which has been mado nvailable during the summer and which might learh away if the soil werc bare; and a more inportant purpose still of this crop, cspecially in some localities, is to have a covering which will protect the roots of the trees and help to loold the snow in winter. $A$ third important use of the cover crop is to have some vegutable matter to plough under in the spring to implove the soil both by ndding humus and by alding nitrogen where leguminous plants are used.

lixperimats with cover crops have been carried on rather evtrosively at tho Central Exprerimental Farm for the past eight years, and it bas been found $t$ at tho most satisfactury plant for this purpose is the common red toler, sown unt liter than tho midille of $J$ uly at the rate of 10 to 12 lbs. per acre, no nurse erop being used as a rule. The hitity vetels (Vicia villosa) has given goorl satistuction in some places, especially in the Niagara peninsula, and has the advantage of growing very late in the autunn. This mi:- Ix sown at the rate of 40 or 50 lbs. per nore with good results. It is not

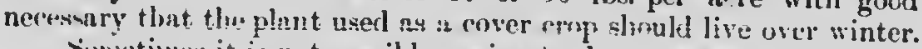

rometimes it is not 1mssible, owing to dry weather, to get a goorl cover crop by sowing about the middle or lattes laif of July. Experiments arc now in progress at the Cuntral Experimental Farm to learn how satisfactory plants in drills two feet or more apart will prove as cover crops. The object of phnting this why is that the seed may bo sown carly ennugh to ensure a good crop and yet the soil nay be eultivated 
until the usual time. Soja beank, horwe beans, ant hwiry veteh are lxoing used for this

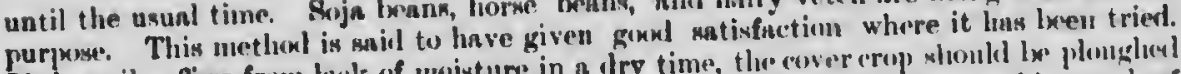

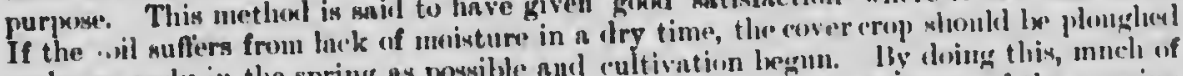
under as enrly in the spring as possible and cultivation legen. lby doing this, mnch of the moisture whicls would otherwise Ine transpircel through the lenves of the growing plants would lo conservel. If, however, thore is always sullicient moisture in the soil

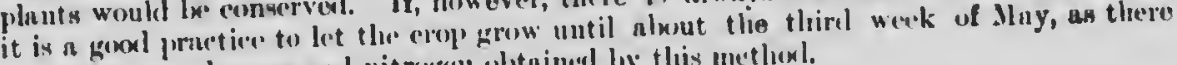

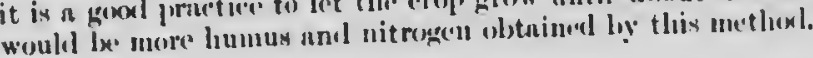

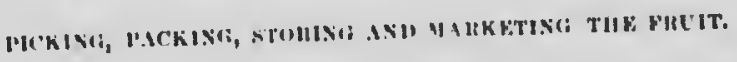

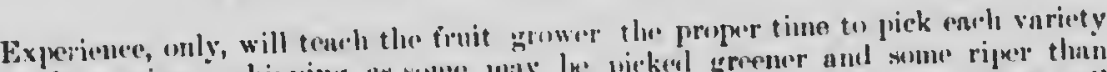

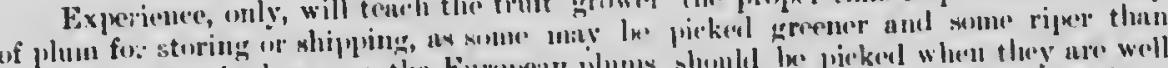

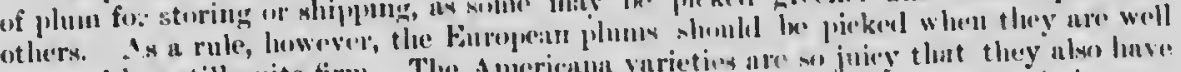

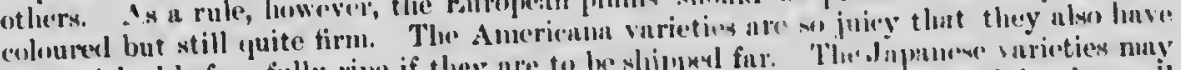

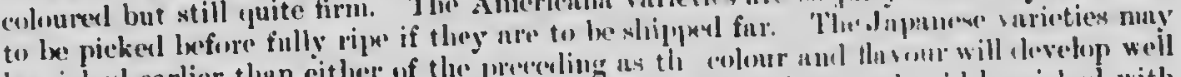

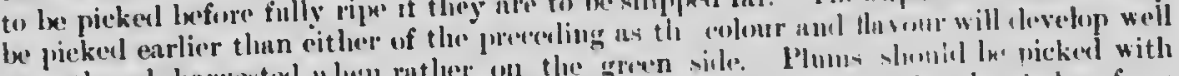

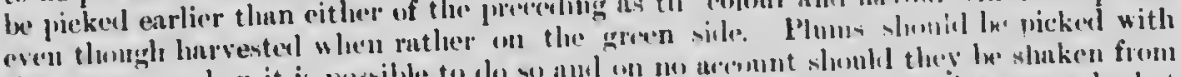

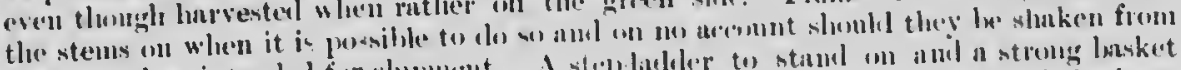

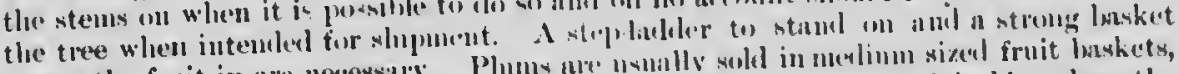

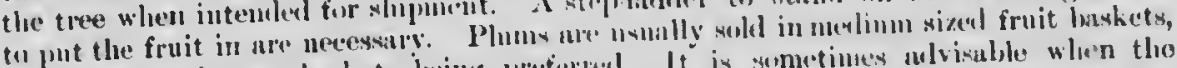

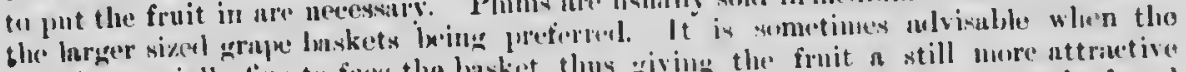
fruit is especinlly line to foue the baskot, thus giving the froit a still nore attractive

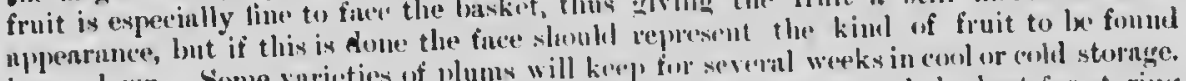

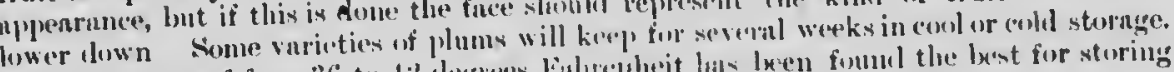

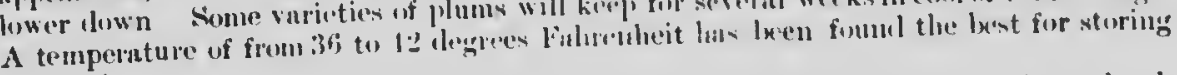
this fruit.

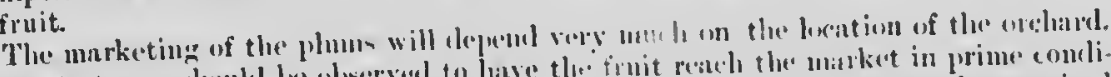

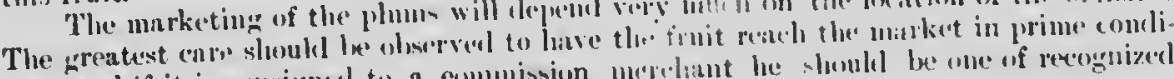

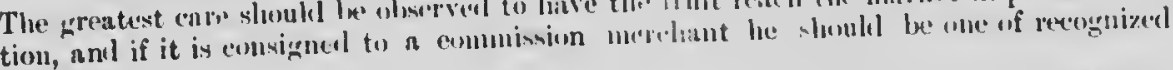
integrity:

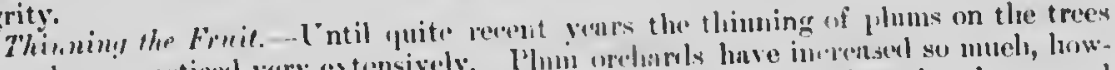

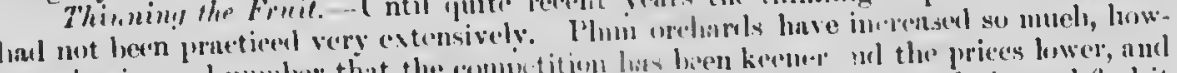

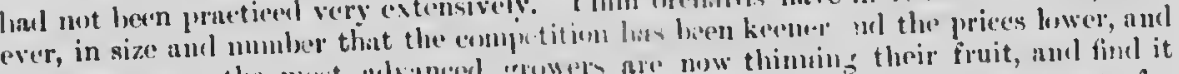

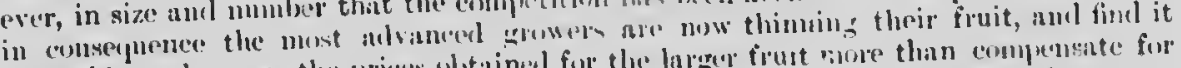

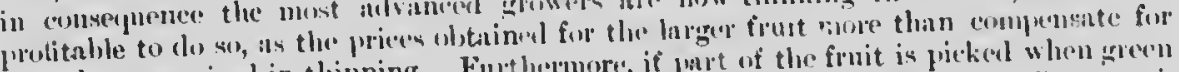

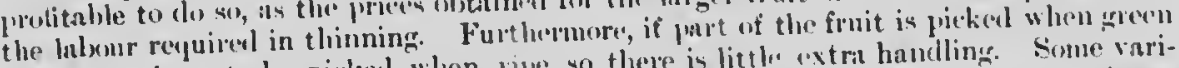

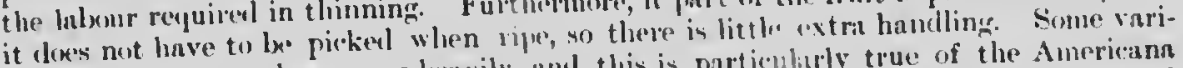
eties of flun trees hear very lestily, and this is particulity thue of the Americann varieties. In consepuence, the fruit wholy unthinnew is meh smaller than it wonld be if there were less of it, and the drain upon the vitality of the tree from the prixluetion of so much sec.l show's itself hefore long, and it trequently lappens, especinlly in poorly tilled and poorly fortilizel urehards, thit trees litwilly bear themselves to death.

The time to thin is after the fruit is well sat and when it is fairly eertain what the (rop is going to lx: There is aways a dropping of pluns lluring the month of June,

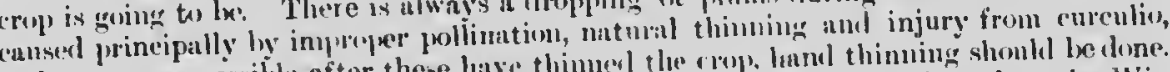

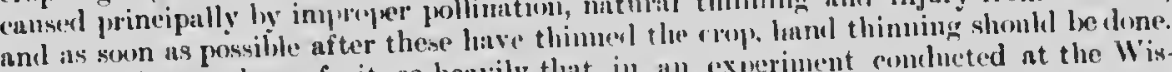
The Americana plums fruit so heavily that, in all experiment conducted at the W'is-

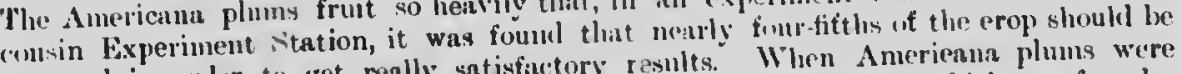
removed in order to get really satisfuctory results. Whon Anerienun plums were thinncel as hasqily as this the fruit was left albout two inehes npart, which wis found a good rlistance in the experiment, but a greater clistauce wis sugrested. In 1897 in experiment in thinning plums was eonductul at the Cintral lixperinental Furm with native plums, when the thinned fruit when rije wis comsillorubly harer than that unthinned. An experiment was also conflucted for the horticultural division at st. Catharines the same year with a Kuropean veriety, when a distinct advantage was obtained ly thinuing. 
Some varicties of Furopean and Japanese plums are left as much ns six inelies apart by fruit grower, and at this distance profituble erops are said to be ubtained of fruit of the bent quality. 'The most profitalle distance apart to leave the plums will be largely goverued by the variety. Some varieties will uot need thinning at all, nnd even where trese are benring heavily the seareity and cost of labour may prevent the profit.
able thinning of the fruit.

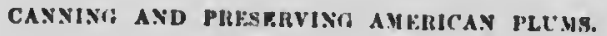

All goul loumewives are faniliar with the way to can and preserve Furopean plumy, but the American varietires repquire different trentment in order to get the most satisfuctory results. Some varieties are thick in the skin, while others nre mone or less astringent, and for these reasons special nethesls are employenl to make the fruit more palntuble. The skin of nmny varieties may be realily removed by pouring loiling water in the fruit und then peeling it. Preserves mole from fruit thus treated is very gowel. Tho skin of some varieties will not break dow'u in rooking, and perling is esjecially desirable in such ensey.

Ameriean plums are not as gookl for eaming as the kuropoan, and, if they are canuml, are best for making pies.

In the autumn of 1902 the following eight varieties of Amerienn plums were preserverl, in order to lenrn what differences there were in these kinds for this purpose:Bixby, Cheney, New Ulm, Mankato, Cottrell, Bouncer, Americun Eagle, Silas Wilson. Thess: were preservel with and without the skin. In nearly every ense the peeled fruit malc the best preserves. The Bixlyy, liowever, cooked with the skin on was the lost of all those testel, linving a letter flavour than any of the others both preles and unpeeled. With some varieties I lb. of sugar to $1 \mathrm{lb}$. of iruit was found to make the preserves too thick; on the other hand, $3 \mathrm{lb}$. sugar to $1 \mathrm{lb}$, of fruit, in some enses did not make them quite sweet enough. None of thic varieties tested were found markedly astringent, thongh most of those conked with the skins had a flavour, not unplensant, but peculiar to the American plums. The proper proportions to be used in preserving each variety will huve to be learned by experience. The following are sone of the notes made on tlic pewerves, arranged in deseending order of merit :-

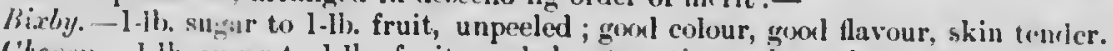

Cheney. - l-ib. sugar to l-lb. fruit, peeled; attractive anber colour, good thatour.

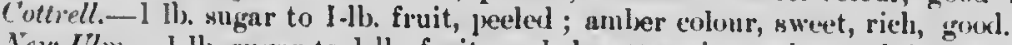

Now Ulm. - I.Ib. sugar to l-lb. fruit, peelerl; attraetive, pale, goorl finvour.

linnencer. - 1-1b. sugar to 1-1b. fruit, peeled; atfractive, lout too thick. gexжl flawour.

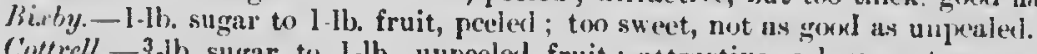
peeled.

Cottrell. - 3-1b. sugar to I-lb. unpeeled fruit; attractive colour, not as goor as ricls.

Silles Wilson.-1-lb. sugar to 1-lb. fruit, pecled; dull amber colom, good, but too

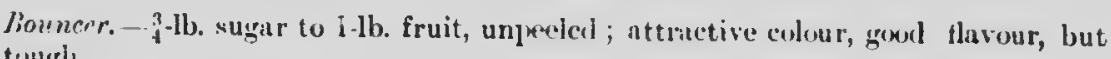
skin tuugh.

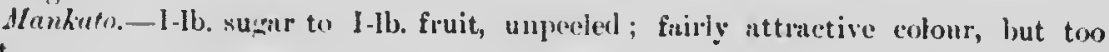
swret.

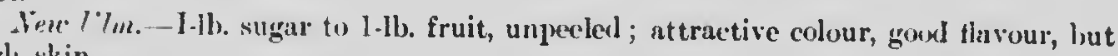
tonglı skin.

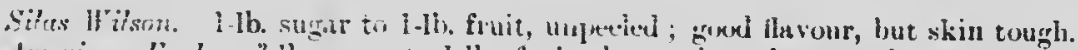
quality.

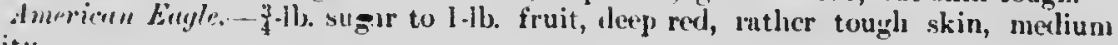
well.

Cंkevry.-1-1b. sugar to $1-1 \mathrm{~b}$. fruit, unpeeled; unattractive colour, but skin breaks 
The following receipes for canning and preserving Ameriean plums, published by the late Prof. Golf, of the Wisconsin Experiment Btation, wern eonsulted and in part adopted in making the preserves :-

"The native plums, especially those with firm pulp after leing treated by any of the methods mentioned below, are well adapted to all purposes for which the foreign plums are userl. As a rule, more sugar is required for the native plums, but the preparations are rich in proportion. The harshness in the skin and stone of some native plums is rcarlily removed by stenming them in an ordinary cooking stenmer until the skin eracks; or pour over thein boiling water to which has been added common baking soda in the proportion of lialf a teaspoonful to a quart. The thicker skinued varieties may be readily peelerl by placing them in boiling waier two or three minutes. The recipes follow:-

Canning.-Pick the fruit when well coloured but a little hard, steam or cuok in a porcelain-lined kettle until tender, put in cans that have first been treated to boiling water, and cover with looiling syrup made of equal parts of granulated sugar and water, filling the can to the top; then run a silver knife around the can inside and let out the air, and seal at onee. Plums cooked in the syrup are likely to be tough. Canned pluns may he used for pics and for mixing with or flavouring other fruit. Plums are often canned without suirar to be used in winter for making fresh plum butter. The juice of canned pluns makes excellent jelly. Onc lady recommends splitting native plums to the stone on one side before cooking, to avoid erumbling.

Drying.-De Soto, Wyant, and doubtless other variet as may be parel, pitted and sprearl on plates, lightly sprinkled with sugar and dried, first in the oven and later in tlic sun. Cook like dricil peaches.

l'lum. Iflly.-The fruit should be gathered when only part ripe-about lialf coloured. This point is very essential. Put plums in a large granite or porcelain kettlo- the latter is best - with barely enough water $t s$ cover them. Cook until tender, but not until they are in a pulpy mass. Having previously eovered a large jar with a clotl, strain the fruit in and let the juice drop througl, but do not squeeze. Whea all has drained tlurough, strain once or twice more through another cloth, until the juice is perfectly clear. Te ouc messure of juice provide one measure of granulated sugar, but do not put together at once. A very important point in the making of all jelly is that only a small quantity slould be cooked at one time. Into a mediuın sized kettle put, say, four tumbleis of juice, let it boil briskly fiteen or twenty minutes, then add the four tumblers of sugar, and in a very short time, ssually from three to ten ninutes, the jelly will be finished, light, clcar, and delieious. To test the jelly, dip a spoon into the boiling juice and sugar and hold it up ; when the jelly clings to the spoon in thick drops, take it off quickly and put into jelly glasses. The plum pulp which is left can bo put through a cullender and used for plum loutter.

Another recipe-Plum prescrves.- 'Take equal weights of fruit and sugar, place in stone jar a layer of fruit, then a layer of sugar, alternating thus until quantity desired is rcaclicl. Let stand over night; in the morning drain off the syrup that will have formerl, into a porcelain kettle, place same over a fire and let syrup eome to a boil, then pour it over fruit in jar again, repent this every day until the fourth lieating, when fruit and syrup are both put in kettle and boiled for a few minutes. Place same in glass jars whilc loot, seal and put awiy in some conl and preferably dark place.

Still unother recipe. - To each pound of plums add a pound of sugar, put the fruit into boiling water until the skins will slip, peel and sprinkle sugar upon eacls layer of fruit in a bowl, allowing them to stand orer night, tlen pour off the juice, bring quickly to a boil, skim and add the pluns, cook very slowly till tender and clear, which will take about one-lialf hour, take them out carctinlly and put into a pan, boil the syrup for a few minutes longer until it thickens, pour it over the fruit, seal or tie them up.

\section{gprayixa.}

It should not now be necessary to point out the advantages of spraying to control insect enemies and fungous diseases, as so mueh has been said and written on this sub- 
ject. The benefieial results where spraying has been thoroughly done and the conditions have been favourablo havo also heen so markerl that the advantages of spraying need nn further proof. It is, however, found necessary to entinually advocate this practice. Fruit growers leeome diseouraged after an unfavourable senson for sprnying, when the conditions are furourable for the development of fungi and rainy weathere prerents the appliention of nixtures altogether or which if applied are washerl off by the min almost as swon as the work is done. With an experience of this kind fruit growers are often inclined to stop spraying and let nature take her course. It sometiues hap$\mu^{\mu}$ 'ns, however, that the mixtures and solutions lasve leen improperly niale or the wrong wixture las been user to destroy a certain insect or dlisease and the fruit grower wonlers why ho does not gret good risults. It is more frequently the case, lowever, that the spraying is not thoroughly done. The olject of spraying is to enver the leaves, fruit and hark with the fungieides and insecticides in order tint the latter may destroy the ingects or diseases which come in eontact with them, and in order that the materials may be rlistributed evenly over the tree it should lo foreed out of the panp in a fine mist-iike sprity, to accomplish which it is necessaly to liave a gool nozzle. If the trees disenses may be affecterl by thew the trees andions at all times when the insects and to the thoroughness and continuity with which the may be injured just in proportion pirtint that which injures encl eneiny. A spraying ealenclar has that he may know the best time to spray for perimental Furm by the Entomologist and the published at intervals at the Central Ex. lirection for the Horticulturist, in which are given full clirections for the preparation of the different formulao recommended and tho time when eacli spraying should be made. Theso calendars are of great value to fruit growers and should be in the hands of everyone. Although a certain number of applications are reesmmended for the prevention and control of the different insects and diseases referred to, it may lo necessary to make more. If, for instance, a henvy rain came on, say, within 24 hours after a spraying had been made, which washed most of the material off, another application should be mado as this might be the very time when the disense or insect which it is desirable to control is making the greatest headway. It is often too late, also, when a spraying for a certain purpose is male, and labour and material are thus practically lost. Spraying is rather expensive when there is a large orehard to cover. It is, therefore, very important that tho right nixtures and solutions are userl; that they aro prepared propeily and applied thoroughly, constantiy and at the right time, and that tho trees bo kept eovered with the mixtures and solutions during
all tho time when injury is likely to oceur.

As the mixtures and solutions may have very injurious effects on the trees if improperly made, and as they may provo of littlo or no value if not applied at the right time, the formula recommended in this Bulletin should be closcly followed.

DISEASES OF THE PLUM.

Ripe Rot, Brows Rot (Monilia fructigena).-The ripe rot causes serious injury to the plum crop every year, especially in the provinee of Ontario. Its spreal is so rapid that a fine erop of plums is soon rendered almost worthless. The disease is usually first noticed on tho ripening fruit by a discoloration of the skin, which becomes brown or black and is soon eovered by small pustules or elusters of sporce, the fruit rotting and falling to the ground. If the weather is danip and sultry the conditions are most favourable to the rotting of the fruit, and a large proportion of the crop will be lestrosed in one day. Sometimes tho diseaso does not slow when the fruit is picked, and infected fruit is shipped and rots before reaching its destination, causing serious loss to slipper or buyer. This discaso is often not recognizer in the spring, at which time it attacks the twigs, fruit spurs and blossoms, causing them to blacken and wither. At this time, also, there is often an exudation of gum from the twigs and spurs, brought
alout by this disease.

Remedies.-The ripe rot fungus spreals by means of spores which germinate early in the spring and penetrate tho twigs from the leaf and flower buds on which theg alighte. 
In order to destroy as many of these spores as possible all diseased fruit slouldbe gathered and burned whether it is on the ground or on the tree. This fruit harbours myriads of spores, which endure the winter and are capable of infecting tlie trees the following spring.

The trees should be thoroughly sprayed in time to destroy the spores before they germinate in the spring. The first spraying slould be made with poisoned Bordenux mixture, or sulphate of copper solutlon, $1 \mathrm{lb}$. sulpliate of copper to 25 gallons of water, shortly befure the buds start to develop, and with poisoned Bordraux mixture just before the blossoms open. These sprayings are very importunt and should never be neglected. After the trees have bloomed they should be thoroughly sprayed agnin with ordinary poisoned Bordeaux mixture, and also ten days or two weeks before the fruit begins to eolour. The trees slouuld also be sprayed with ammoniacal copper carbonate when the fruit is beginning to ripen. This will destroy the spores which appear in great numbers on the mature plums, and not discolour the fruit. Plums which touch one another on the tree give very favourable conditions for the spread of the disease from one fruit to another. Being close together, noisture is retained on the skin and the spores whieh may be on one fruit germinate readily and soon infect the next, and thus the disease spreads rapiclly. Thinning the fruit would make the eonditions muel less favourable for the develipment of the disease. All discolourcel or al:ad woor should be eut out and burned in the meantime. If spraying is thomughly done the injury from this disease will be much lessened.

Buack Kуот (Plourightia morbosa). - The black knot is mu\% feared liy the avenge

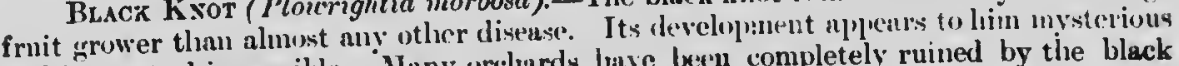
and its eontrol impossible. Many urchards liave been completely ruined by the black knot, whicl spreads very rapid!y once it has gained a foothold in the orchard. Trees whicl have been eared for froin the beginning are, however, not so subjeet to this disease, and if treated properly from the outset it may be kept in eheck and even eradicated altogetlier, if infection does not take place from neighbouring orchards or from planting trees from infected uurseries.

$\mathrm{T}$ ie black knot is a fungus which spreads ly neans of spores. A spore is blown through the rir and alights in the axil of a leaf, on a spur, or on some otlier part of the tree where it ean get a resting place. When conditions are favourable the spore germinates, penctrates the tree and grows in it. In the spring yellowish swellings appear on the branehes, the first visible indication of the disease, and during the months of May and Ja re become darker in colour with a velvety surface whieh is caused by innumeruble spores which eover the exposed part of the lump or knot. These : pores are soon blown away and alight on other branches and trees. These germinate and penetrate the tree as already described and new knots develop in time from them. A second crop of spores is produced in autumn or early winter, but these are not liberisterl from the knot until the latter part of the winter or early in the spring when they are distributed and alighting on the trees germinate as the others. The mycelium is nut all exhausted hy the production of the knots in spring, but is capable of producing more from the same knot the following yenr. The disase is also liable to be carried from one orchard to another, which makes it difficult to control somctimes. To figlit a discase which is provided witl such sure means of reproduction and disscmination requires watchifulness, thoroughness, and continuous effort until it is eradieated.

Revedy.-If trees are alrealy barlly affected with this disease the best plan is to cut them down and burn them. If only moderately affected, the knots should be removed and burned ind the orchaid thoroughly cultivated and sprayed. Vigorous trees are not so subject to the disease as those nuking little growth, and vigorous trees will recover more quickly from wounds made ly removing the knots.

As the early sporis alpear in the latter part of spring or early in summer, the knots should be romoved as swon as possible nfter they appear. When they are on

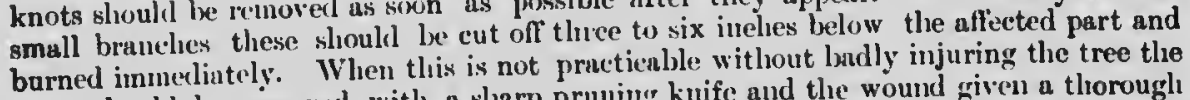
knot should be removed with a sharp pruning knife and the wound given a thorough painting with pure kerosene, after whicl it should be covered with grafting wax or lead 
paint. Great eare should be taken to prevent the kerosene running on the braneh as it painting with kerosene more readily see when a wound has somo colouring material in tho kerosene, one can The treatment alrea a wound has been painted well. All knots should be bumed. disease is known a fruit grower is only for tho knets. Unless the lifo history of this appeared that it was all that might imagine that if the knots were removed as they moved before the spores were fis necessary. This might be all, if the knots were rewould be capable of producing myrind distributed, but if one knot wero missed it orehard.

The advantages of spraying with Bordeaux mixture were elearly demonstratod in an experiment conducterl at the Cornell Experiment Station, the results of which were published in Bulletin No. 81 of that station. It was found that the number of knots was reduced from 2,000 to 165 by spraying.

A large proportion of the lnte spores which are exposed in late winter or early spring nnd are ready to germinate when conditions are favourable, would probably be destroyed by an application of sulphate of copper solution at the rate of $1 \mathrm{lb}$. of sulA second spraying of poisoned Bordeaurer when the trees nre still dormant in the spring. bucly are breaking, which would also $x$ mixture should be made just as or beforo the plum and for insects, and a third spraying good time to spray for otler diseases of tho are at the velvety or spore producinging should be made at the time when the knots application would also probablyeng stage in order to destroy these spores. A fourtl le taken to prevent the probably bo well worth the expense. Every precaution should in Canada.

Spot or Blight of tue Native Plum (Cladosporium carpophilum, V. Thumen). The alinost complete absence of native plums during reent years in the Ottawa district and elsewhere in eastern Ontario and the province of Quebec, is due in a large measure than lialf its and falls to the ground without ripening. When affec' ad by the disease it shrivels later, small pale green or rellow patcheg. If the fruit is examined when half grown or finally they are about lalf an patches will be noticed. These gradually enlarge until colour, of more irregular outlinch in diameter, at which time the blotches are darker in not, as a rule, seriously affected with re raised on the skin. The Americana plams are Nigm varicties.

Remerly. - This fungus is nearly related to the apple spot and can be satisfactorily treated in much the sanie way. The trees should be sprayed with Bordeaux inixture just after the blosscms fall, again two weeks later, and a third time two weeks after the second application. It is also advisable to spray a fourth time witl ammoniacal copper carbonate just when the fruit is beginning to colour. The native varieties ripen early, stuined. The ammoniacal fruit. This remedy has beopper carbonate does not leave a noticeable stain on the Ottawa who has thus been very satisfictorily used by ono grower in particular near varieties may be top grafted on to grow native plums very profitably. Tho Ainericann disense as the latter are not on the native nnes with the result that there will be less looked after or bearing poor fruit should be burned nntive. All other plum trees not

Sinot-Hole or Leaf-Spot (Cylindrosporium padi).-The first indications of this diseaso are small, yellowish spots with :eddish margins, which appear on the young leave. These spots increase in size and finally reach a diameter averaging about one-eighth to ono-sixth of an inch. When fully grown, the central part dries up and drops out, leaving a clemn cut nround the margin, very suggestive of a shot-loole, after whicl the disease is named. When these spots cecur in large numbers, as they frequently do, so nucli of the leaf is destroyed that it drops prematurely. The early dropping of the leaves pro- 
vents the fruit, twign and buds reaching their full development, and on this account cutuses scrious injury where the disease is troublesome. Prof. Beach, Geneva, N.Y., who conducted experiments to control this disease on European plums, found the Bordcaux mixture satisfactory and recommends three applications. The first abont ten days after the blossom: 1 fall ; the second, three weeks later, and the third, three or four weeks nfter the second. At the Centrnl Experimental Farm, Americana and Nigra plums have bren thoroughly sprayed with Bordeux mixture from three to five times, without satisfactory results. Somo varietics are more susceptible to the discaso than others.

Puex Pockets-Exoancus (Tuphrina).-The disense of plum known as ' nlum pockets' does not cause widesprend injury, but in some places does occasion considcruble loss. The mycelium of the fungus which causes the pockets lives year after year in the same tree, and thus it is not necessary for a tree to be infected by the spores cvery yoar in order to perpetuate the diserse. The fruit is affected soon after the trees have blossomed and is indicated by the unnatural swelling and bladder-like appea muce of the fruit and by its unusual yellow colour. When the spores of the discrse which has been working inside the fruit appear on the surface they give the pockets a gray appearanco. Later on, the pockets turn almost black and fall to the ground. The leaves and twigs are also noticeably affected with this disease, the former becoming curlerl and unhealthy looking and the twigs swelling unnaturally. There is no known offective remedy for this disease, but it will probably be much lessened if the affected parts with tho pockets are cut off and burned.

Gommosis. - The exudation of gum from plum trees, which is known as gumning or gummosis, is quite common in plum orchards. It has been given careful study and is not attributed to any one disease. The conclusion reached is that any weakening of the tree by severe pruning, by winter, by injury to the trunk or branches, or by diseases of different kinds will cause gumming. It is often very noticeable when trees aro affectod with the Monilia or Ripe Rot fungus. It appears to follow any breaking or injury to the wood tissue.

Mice.-Mice often girdlo the trees in the orchard in winter, especially when it is in sod or when there is rubbish lying about in which they like to harbour. Everything in the way of rubbish should, however, be removed before winter. Their depredations may be prevented either by wrapping the trunks with building paper in autumn and banking up the earth about the base to the height of about a foot; by cncircling the trunk with fine galvanized iron nctting ; or by using the veneer protectors used to prevent scalding. Where the latter are used the earth should be banked up a little at the base to prevent the mice from going underncath.

If a tree is girdled by mice it usually dies. If, however, as soon as the injury is noticed, the wound is clcaned and covered with grafting wax and wrapped with cloth so that the air is excluded and the wood prevented from drying out, the sap which rises through the soft wor-1 will continue to do so and returning through the innor bark, growth will be made all around the upper part of the wound, and if tho latter be not too large there is chance of its healing over. If, however, the wood becomes dry before the landage is put on it will almost certainly die. When the wax and bandage are applied the tree should be headed back considerably to lessen the amount of transpiration of moisture, as thcre will not be as much sap riso as if the tree were uninjured. Girdled trees are sometimes snved by connecting the upper and lower edges of the girdlo with scions, which are inscrtel all around the trunk. Mice may be destroyed in the orchard by using a mixture of one part by weight of arsenic with thrce parts of corn meal. To use this safely nail two pieces of board each six feet long and six inches wide together so as to make a trough. Invert this near the trees to be protected and place about a tablespoonful of the poison on a shingle and put it near the middle of the run, renewing the poison as often as is neccssary. 


\section{PLOM INSEOTS.}

\section{By Janes Fretcher, Entomologiot and Bolanish.}

Insects may be divided into two classes according to the nnture of their mouth parts. Those of the first or larger division, Biting Insects, are furnisheri witl mandibles or biting jaws, by means of which they consume the substance of their food, as cater. pillars, beetles, dc. The second class, Sucking Insects, have, instead of mandibles, beak or tube, by means of which they suck up their food in a liquia form from beneath the surface, as the true bugs, plant-lice, \&c. As regards the insects of the first class, all thant it is necessary to do is to place on the food plant some poisonous material which will be eaten with the food. With the second class, however, this would be useless, for thry would push their beaks through the poisonous covering on the outside of the ford plnut and extract from the interior the juices upon which they live. For this class, bodies.

\section{INSECTICIDES AND FUIYGICIDES.}

The following are the formula of standard remedies which are recommended by the Entomologist and Botanist:-

\section{Papje Greex.}

For Biting Insects.

Paris green.......................... I lb.

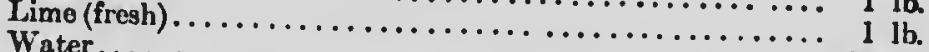

....200 gallons.

For dry application.-1 lb. Paris green with 50 lbs. fluur, land plaster, slaked lime or any otlicr perfectly dry powder.

\section{Kerosene Eytusioy.}

(RLLET-MURnard Foriula.)

For Scale insects and I'lar.tlice.

Kcroseno (coal oil). ..................... gallons

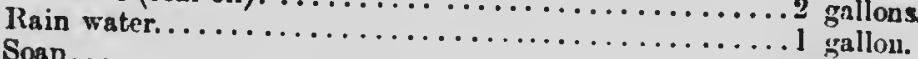

Soap........................

Dissolve soap in water by boiling; take from fire, and, while hot, turn in kerosene and churn briskly for five minutes. To be diluted before use with nine parts of water.

\section{Wrale-oil Soap.}

For scalc-insects (young) .......... lb, in 5 gallons water.

For aphis.......................

For Sin José scale (in winter)........2 lbs. in 1 "

\section{Tonacco avd Sonp Wash.}

For Pl-ntlice or Aplis.

Soak in hot water for a few liours 10 lbs. of tobacco leaves (home grown will do); strain off, and ald 2 lbs. of whale-oil soap. Stir until all is dissolved, and dilute to 10
gallons. Apply carly and two or three times at short intervals. 


\section{Polbored Bordzudx Mixture.}

For Fungi and Inscels on Fruil-trees.

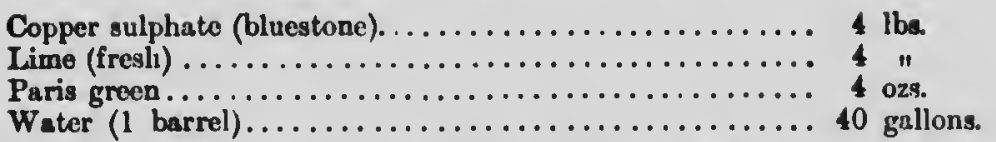

Dissolve the eopper sulphate (by suspending it inside a wooden or eartlen ressel containing 4 or 5 or more gallons of water). Slake the lime in another vessel. If the lime, when slaked, is lumpy or granular, it should be strained through eoarso sacking or a fine sieve. Pour the copper sulphate solution into a barrel, or it may be dissolved in this in the first place; half fill the barrel with water, add the slaked lime, fill tho barrel with water and stir thoroughly. It is then ready for use.

Stock solutions of dissolved copper sulphate and of lime may be prepared and kept in separate covered barrels throughout tho spraying season. The quantities of blueatone, line and water should be carefully noted.

\section{Copper Sulphate Solutioy.}

$$
\text { For F.ngi. }
$$

Copper sulpliate (bluestone $) . \ldots \ldots \ldots \ldots \ldots \ldots \ldots \ldots \ldots, 1 \mathrm{lb}$.

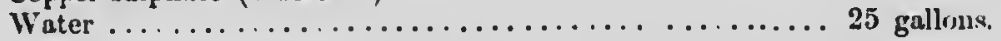

As stoon as dissolved it is ready for use. For use only before the buds open.

\section{Aymosucal Coppen Carbonate.}

For Fungi.

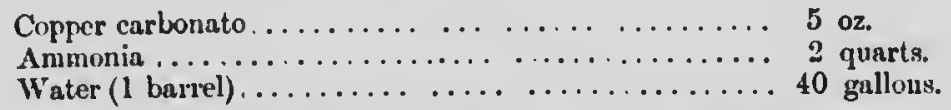

Dissolve the copper carbonate in the ammonia. The ammonia and concentrated solution should be kept in glass or stono jars, tightly corked. It is ready for use as suon as diluted with the 40 gallons water. To be used when Bordeaux cannot be applied on account of staining the fruit.

\section{THE WORST ENEUIES OF THE PLUM TREE.}

\section{ATTACKIIG THE FOLIAGE.}

1. The Fye-spotTr.D BuD-моти (Tmelocera ocellana). - Small, dark brown eaterpillars, $\frac{1}{4}$ of an inch in length, with black heads and collars, destroying the bucls when just unfolding and later attacking the leaves, two or three of which they attach together, feeding inside. They also sometimes bure down the centre of the twig. Remedy:Spray early with a strong Paris green wiush (Paris green 1 pound, fresh lime 1 pound, water 100 gallons).

2. The Cigar Case-mfiarer (Colcophora fletcherclla). - Small orange-coloured caterpillars with bluck lieads, encased in brown leatliery cigar-slaped cases, which they carry about with then. They pass the winter as caterpillars on the twigs, and cluster around the opening buds, injuring the foliage and flowers. Remely.-Spray carly with the wash mentioned under No. 1 abore, or with kerosene emulsion (Formula II). 
3. Test Catirpiluars (Clioiocampa). - Two kinds attack the foliage of the plam as well as many other trees. The Apple-tree Tent Caterpillar forms a tent in the fort of on the silo of a brancl Tent Caterpillar does not make a tent but spins a flat mat of eilk resort when not feeding on the trunk; to these resting places the young caterpillar expanding about 11. The maturo insects aro thick-bodied, reddish-bmwn moths These bands are pillar. During July in the first named, but dark in the moth of the Forest Tent Caterin which state the inscct passes lay rings of about 200 eggs on the twigs of the trees, clusters during the wintor. Remedres:-Collect and destroy the egg

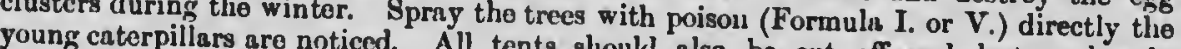
before the leaves lide then. All tents should also bo cut off and destroyed early

4. Plant-lice on Apund (Aphis prunifolii, IIyalopterus pruni). -In appearance and habits much the same as the Apple Aphis, clustering on the underside of leaves, sucking out the juices and causing the leaves to become wrinkled and twisted. Remedies:-Whale-oil soap $1 \mathrm{lb}$. in 6 gallons of water, tobacco and soap wash (Formula IV) or kerosene emulsion (Formula II). Begin to spray when the plant-lice are first

5. Tho Pear-tree Sluo or Caerry-tree Sluo (Eriocampa cerasi).-In June and August, slimy, greenish-brown, slug-like caterpillars, $\frac{1}{2}$ inch long, feeding on the upper surface of the leaves, often doing eonsiderable damage to plum trces. Remedies:-Spray with a weak solution of Paris green or dust with freshly slaked lime, or Paris green diluted with 50 times its weight of some dry powder.

6. Plum Leap Caterpillars.-There aro other kinds of leaf-eating caterpillars which occasionally occur in sufficient numbers on the folinge of plum trees to do serious injury. Remedy :-Spraying regularly with Formula V. will prevent injury from thicse

\section{ATTACKLNG TIIE WOOD.}

7. The SHot-Boren (Xyleborus dispar). - Small blackish beetles, which bore into the trunks and limbs, causing serious damage in apple and plum orchards. Remedy:Wash the trees liable to attack three times, early and late in $J$ une and once in July, with the following :-Soft soap, 1 gallon; water, 3 gallons; carbolie acid, $\frac{1}{2}$ pint.

\section{OCCURRING ON TUE BARE.}

8. The Sax Jost Scale (Aspidiolus perniciosus). - Minute, almost circular scaleinsects, one-thirtictl of an inch wide, shaped like an inverted saucer, with a depressed ring around a central point ; inside this ring, black or dark colourcd. This very inconspicuous insect when in small numbers is easily overlooked, but when abundant gives to the bark a dirty, scurfy and grayish colour, as though dusted with ashes. Remedies:This is by far the most diffieult insect to cradicate which the fruit growers lave cver ordin a rearents the best results arc: (1) the onc may aulvantageously be applied in May, just before the foliage is so thick that it is and the sccond one after of the trec), the first summer sprnying in the middle of June, with a thorough ger aral spraying with pieked; this to be followed in winter or spring to one gallon of water boiled together until dissolved. (2) Whale and $\frac{1}{2} \mathrm{lb}$. of sulphur imperial gallon of water, the best time to spred. (2) Whale-oil soap $2 \frac{1}{2}$ lbs. to the rring. The soap should be dissolved in hot water and applied as hot as is practicable. 
9. The New Yonk Plum Scale (Lecanium ceraijex). - Conspicuous, daty brown, hemispherical scales, about $\frac{1}{8}$ of an inch long by $\frac{1}{1}$ of inch wide, occurring at all times of the year, elustered along the small lormeches, particulai,y along the lower siles. The presenee of this enemy upon a plum tree iнny be detecter; especially in July an 1 Iugust and also in the spring, by the filthy black condition of the lark due to the growth of a fungus upon the copious deposit of honey-dow which is emitted by this young scale insects during the tine of their growth. Remedies:- Spray thes trees during the winter with kerowene mudsion (Fornulin II.) diluted with four pourts of water, or with the whalevil snap solution (Frrnula III.)

\section{AT'ACKISG TIE FRUIT.}

10. The Puun Cencurin (Conntrachelus nonuphar). - Small, rough, grayish beetles about $f$ of an inch long. The females, in the operation of egg-lnying, mako upon the sides of plums small crescent-shatped narkw, with a single hole in the centre of each. An egg is laid in the central spmt, from which hetches a whits grub; this soon destroys the fruit. Remedies:- (1) The inature beetles feed in early spring upon the unoprnerl buds and afterwards : pon the youn leaves and inny be reached by spraying the trees before the buds open with Paris green (Formula I), repenting this as soon as the fruit lans formed and spraying ten days later witls the poisoned Bordenux inixture (Formula V). (2) The beetles are sluggish in the enrly inorning and drop from the trees if a sudden jar be given to the truuk. This jarring, if repented every day or two over a slieet or other receptsele, wil! be the neans of greatly lessening the numbers of the mature insects. The beetles drop reudily anl lie fiuietly for some time, when they ean be easily collected and destroyed.

IFote.

The operution of 'spraying' eonsiste of applying liquids by means of a force pump and spraying nozzle, with such foree as to break up the liquid so thooughly that it falls upon the plants trented as an aetual mist or spray. The word 'spraying,' however, to many who endeavour to praetise this operation, has still little more meaning than doing something in any sort, wav, to fruit trees with a spraying pump. Sueh terms as 'sprinkling' and 'slowering ure inaecurate for the operation hero intended. Unfort unately, mueli of the so-ealled spraying as usually earried out, could more aceurately be designated as sprinkling or showering, which deseribo mizch less careful and less even distribution of liquids.

The Entonologist and Botanist will be glad to give furthor information concerning attacks upon erops by insects if inquiry be niade by letter. 


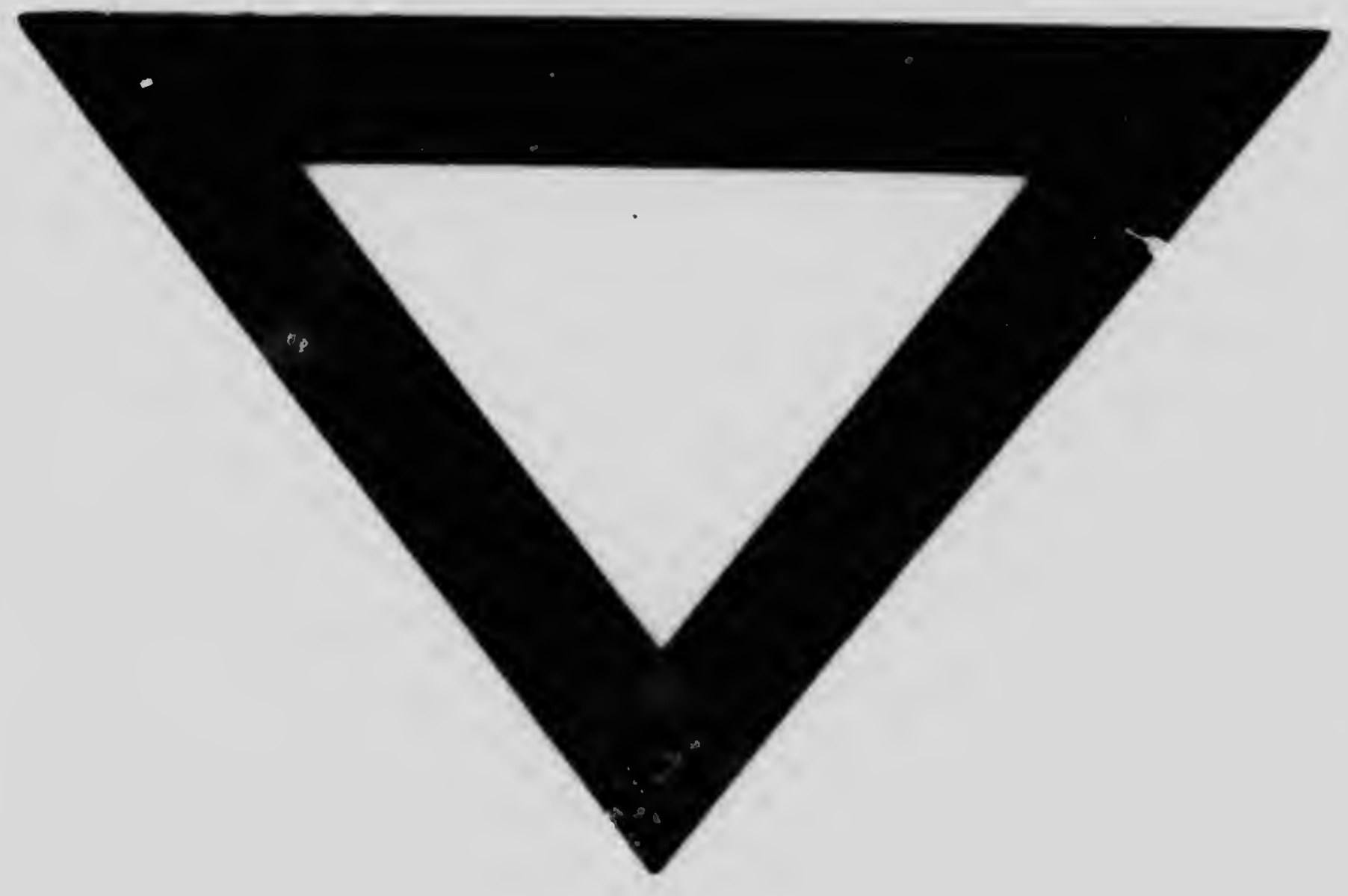

